\title{
26. LATE CRETACEOUS ARCHAEOMONADACEAE, DIATOMACEAE, AND SILICOFLAGELLATAE FROM THE SOUTH PACIFIC OCEAN, DEEP SEA DRILLING PROJECT, LEG 29, SITE 275'
}

\author{
Marta Hajós, Hungarian Geological Survey, Budapest, Hungary \\ With Additional Contribution From \\ Herbert Stradner, Geological Survey of Austria, Vienna, Austria ${ }^{2}$
}

\begin{abstract}
Site 275 of the Deep Sea Drilling Project is located in the South Pacific, at the southeast margin of Campbell Plateau, on a relatively elevated bottom eroded by bottom currents. Under a thin layer of Recent-Pleistocene foraminiferal ooze, Late Cretaceous siliceous sediments were drilled: a bright-yellow upper unit is 14.5 meters thick and is underlain by a dark-brown unit down to 62.0 meters. At this depth further drilling was prevented by hard siliceous shale. The two units are distinctly different both lithologically and paleontologically. Unit 1, down to 14.5 meters, consists of diatom-radiolarian ooze with abundant siliceous microfossils, mostly of cold-water oceanic plankton, such as Archaeomonadaceae, Diatomaceae, Radiolaria, Silicoflagellatae, with accessory sponge spicules. Microfossils make up $60 \%-90 \%$ of the sediment. The underlying Unit 2 consists of olive-gray partly detrital clayey silt with thin intercalcations of lithified siliceous shale. It yielded Radiolaria, Dinoflagellata, and colonies of green algae, but no Archaeomonadaceae, Diatomaceae, or Silicoflagellatae.

The microfossil assemblages of 21 samples from Cores 1 and 2 of Unit 1 were examined and evaluated in detail. Thus far, 158 species have been determined, including 4 new genera, 57 new species, and 3 new combinations, all extinct. The sediment is of Late Cretaceous age. Based on the abundance and vertical ranges of the species, 9 biozones and 12 subzones have been established.
\end{abstract}

\section{INTRODUCTION}

Site 275 of the Deep Sea Drilling Project was drilled 46 March 1973, in the South Pacific, at the southeast margin of Campbell Plateau (Figure 1). A veneer of a few $\mathrm{cm}$ of a Recent-Pleistocene white foraminiferal ooze with manganese nodules, as well as 62 meters of siliceous sediments of Late Cretaceous age were drilled. Two units were easily defined both lithologically and paleontologically (Figure 2).

The uppermost unit, Unit 1 consists of relatively soft bright-yellow diatom-radiolarian ooze, rich in siliceous microfossils. Unit 2 consists of dark-olive-gray, partly detrital clayey silt and silty clay with thin intercalations of lithified siliceous shale. It contains no siliceous microfossils except for a few radiolarians, but does contain some nannoplankton, palynomorphs, and green algae.

Initially 24 samples from 5 cores and 5 Core Catcher samples were investigated. For preliminary examination

\footnotetext{
'Publication authorized by the Director of the Hungarian Geological Survey.

${ }^{2}$ Publication of contribution and electron micrographs on the ultrastructure of the mierofossils authorized by the Director of the Geological Survey of Austria, Vienna, Austria.
}

preparations were made merely by embedding the sediment in hyrax without the use of any chemicals and/or sieves, in order to avoid mixing the microfossils. The samples from Cores 1 and 2 (Unit 1) contain many siliceous microfossils. This paper deals only with the siliceous microfossils (excluding radiolarians) of Unit 1 (Table 1).

\section{TECHNIQUES}

For detailed investigation and microphotography the material was prepared as follows: $1 \mathrm{cc}$ of each sample was disaggregated with a $10 \% \mathrm{H}_{2} \mathrm{O}_{2}$ solution, and the microfossils were separated from quartz, glauconite, feldspar, and other mineral grains, by washing with and sedimentation in distilled water. Sieves were not used, and accordingly, the undamaged tests were well suited for light microscopy and for electron microscopy and fine-structure microphotography. The prepared microfossils, mounted in hyrax medium $(n=1.65)$, were covered with $18 \times 18 \mathrm{~mm}$ cover slides. For each sample, the field of vision of two slides was thoroughly examined and evaluated row by row. Four abundance categories were distinguished (Table 1). Particular attention was paid to some very characteristic, short-range, zone marker species even if they were represented by only a few specimens, or if they were fragmentary, due to their 


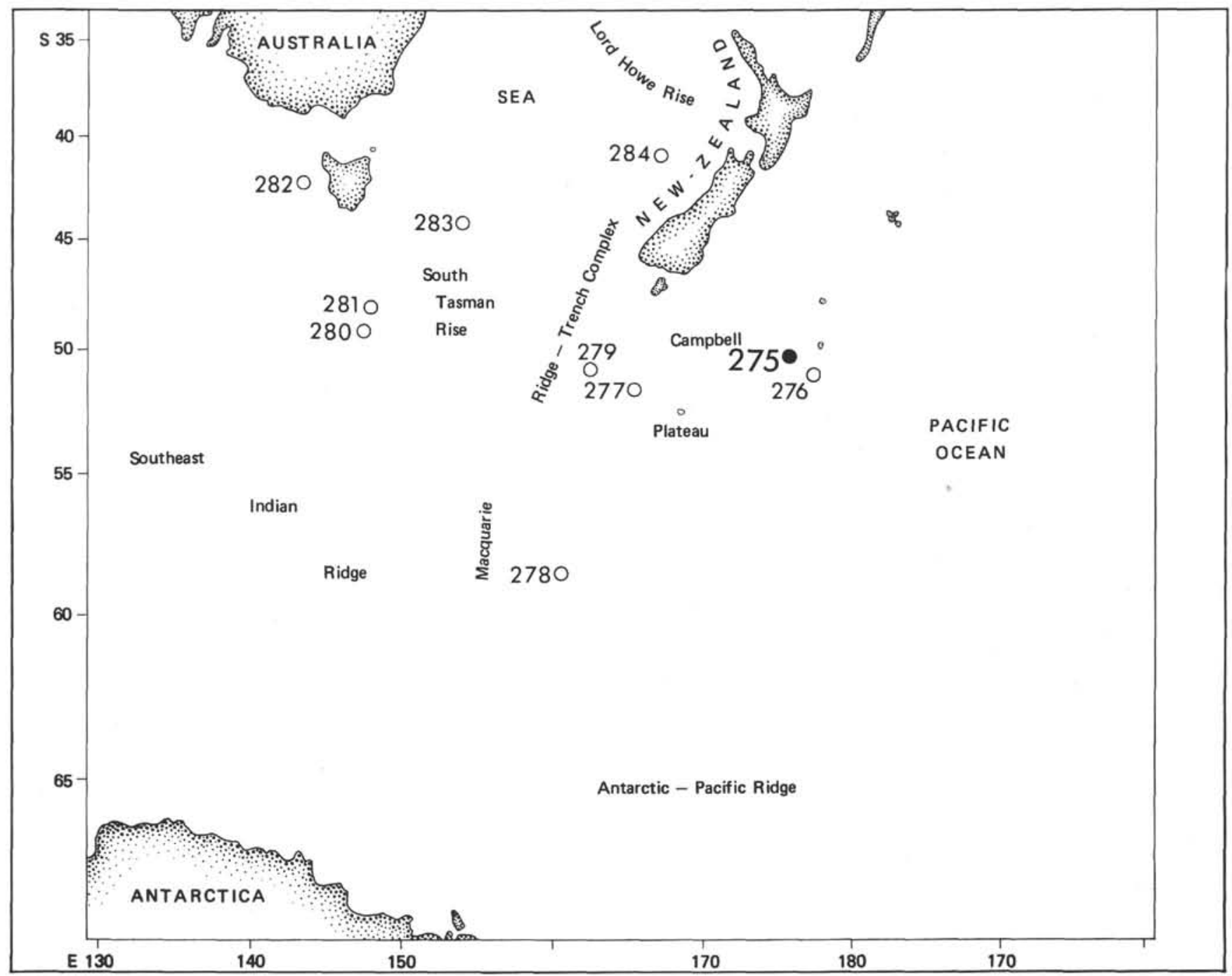

Figure 1. Location map of drilling sites in the South Pacific Ocean, Leg 29, Deep Sea Drilling Project.

relatively large size and thin tests (e.g., Huttonia punctata, Kentrodiscus aculeatus, and Tubularia antarctica.)

For visual microscopy and microphotography, an Amplival microscope was used (oil immersion objectives, with a magnification of $\times 40$ and $\times 100$, oculars with a magnification of $\times 4$ and $\times 15$. Stereoscan microphotographs are the courtesy of Katharina PerchNielsen (Universitets Institut for Historisk Geologi og Palaeontologi, Copenhagen, Denmark). Transmission electron micrographs were made by Herbert Stradner (Geological Survey of Austria, Vienna, Austria). Their work made it possible to study the morphological microstructure of the tests, not discernible under ordinary light microscope. This is of paramount importance for the correct description of extinct species and for the interpretation of their phylogenetic relationships.

\section{BIOSTRATIGRAPHY}

Archaeomonadaceae, Diatomaceae, Radiolaria, Silicoflagellatae and siliceous sponge spicules make up $40 \%-92 \%$ of the sediment of Unit 1. Mineral grains are: quartz (overwhelming), with subordinate glauconite and some feldspar. Calcite and other carbonate minerals are completely absent. Even the few agglutinated foraminifera (fine-grained Bolivinopsis spectabilis) obtained from Site 275 are siliceous. This suggests that the medium may have been free of carbonates at the time of sediment deposition.

The transitional sediment between Units 1 and 2 contains scarce Silicoflagellata only. Unit 2 itself has yielded only a few Radiolaria specimens. However, this unit may have been rich in siliceous microfossils, but their tests, consisting of amorphous silica, were dissolved during diagenesis. The originating silica gel contributed to the lithification of certain layers, producing the hard siliceous shales encountered.

The 21 samples of Cores 1 and 2 are very rich in microfossils. In Tables 2 and 3 only the most common or stratigraphically most important species are enumerated. The listing in the tables includes 158 species that have been determined as well as 4 new genera, 56 new species, and 3 new combinations. 


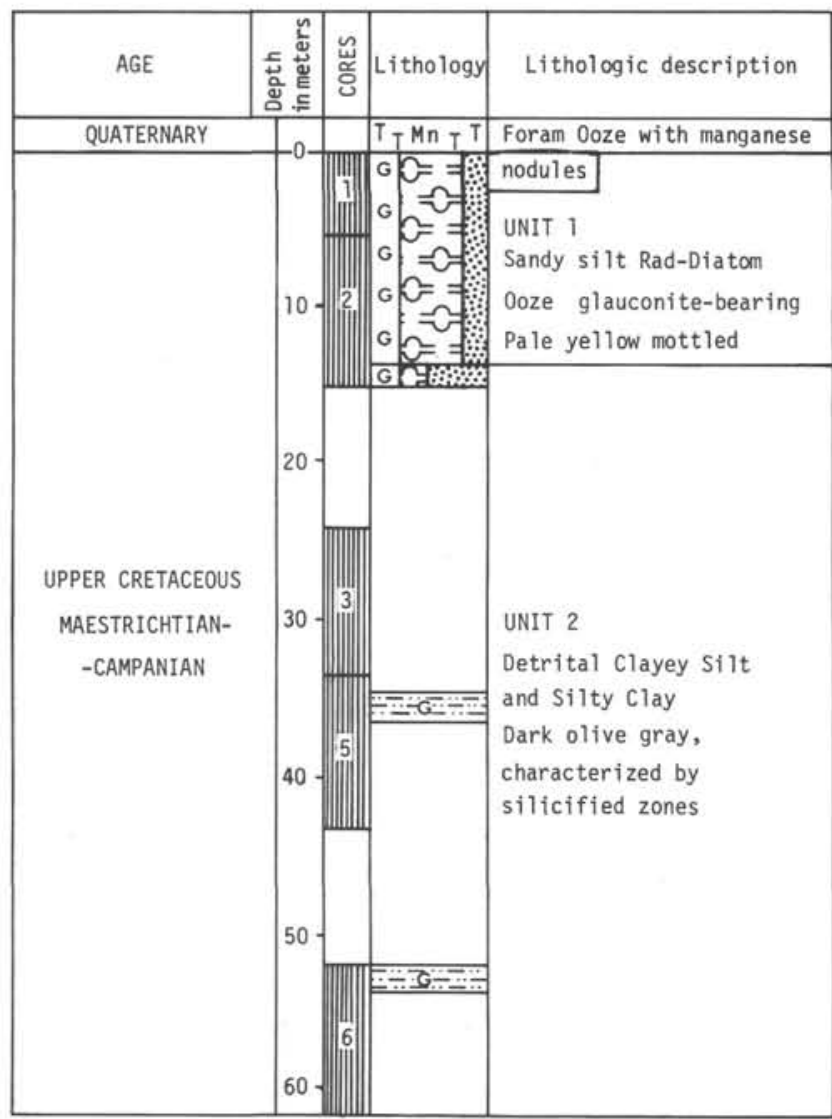

Figure 2. Stratigraphy and lithology of Site 275.

Preference was given to species conveniently described in the literature (Deflandre, 1950, 1969; Gleser, 1962, 1963, 1966; Hanna, 1927, 1928, 1934; Jousé, 1949, 1951a, 1951b, 1955, 1963; Loeblich et al., 1968; Long et al., 1946; Mandra, 1968; Pantocsek, 1886-1905; Proschkina-Lavrenko, 1949; Rampi, 1940; Schmidt, 1874-1959; Strelnikova, 1965a, 1965b, 1971; and van Heurck, 1896). The abundance, range, and preservation of the species were also evaluated (Tables 2 and 3 ).

The 125 species and varieties disappear within the Cretaceous and they are known to occur in the Campanian and Maestrichtian. Seventeen species are known from the Paleocene, nine from the late Eocene, and only seven from the Miocene (or at least some closely related variety is known from the Miocene). A similar statement has been made by Pessagno (Site Report, Chapter 2, this volume) who attributed the radiolarians determined in samples from Core 1, Section 1 to Core 4, Section 2 as correlating with Californian occurrences, the Patulibracchium dickinsoni Zone, dated latest Campanian. Taking this into consideration, the age of the sediments studied by this writer is late CampanianMaestrichtian.

\section{RANGES OF SELECTED TAXA AND BIOSTRATIGRAPHIC ZONATION}

From the intensive study of the siliceous microfossils of Cores 1 and 2 of Site 275, the ranges of selected
TABLE 1

Siliceous Microfossils of Leg 29, Site 275 in Lithologic Unit 1

\begin{tabular}{|c|c|c|c|c|c|}
\hline \multirow[b]{2}{*}{$\begin{array}{c}\text { Sample } \\
\text { (Interval in } \mathrm{cm} \text { ) }\end{array}$} & \multicolumn{5}{|c|}{$\begin{array}{l}\text { Marine, Planktonic Archaeomona- } \\
\text { daceae, Diatoms, Silicoflagellates } \\
\text { and Porifera Spicules }\end{array}$} \\
\hline & 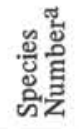 & 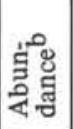 & 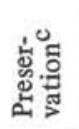 & ฮั & $\stackrel{8}{\stackrel{8}{\alpha}}$ \\
\hline $1-1,118-120$ & M & A & M & I & \multirow{22}{*}{  } \\
\hline $1-2,40-42$ & M & A & G & \multirow{6}{*}{ II } & \\
\hline $1-2,117-119$ & M & C & G & & \\
\hline $1-3,40-42$ & $\mathbf{P}$ & C & G & & \\
\hline $1-4,40-42$ & $\mathbf{P}$ & C & G & & \\
\hline $1-4,120-122$ & $\mathrm{P}$ & C & G & & \\
\hline $1, \mathrm{CC}$ & $P$ & A & G & & \\
\hline $2-1,25-27$ & $\mathbf{P}$ & A & G & \multirow{3}{*}{ III } & \\
\hline $2-1,40-42$ & $P$ & A & G & & \\
\hline $2-1,120-122$ & $\mathbf{P}$ & A & G & & \\
\hline $2-1,130-132$ & $\mathbf{P}$ & A & G & IV & \\
\hline $2-2,60-62$ & $\mathbf{P}$ & A & G & \multirow{2}{*}{ V } & \\
\hline $2-2,120-122$ & $\mathbf{P}$ & A & G & & \\
\hline $2-3,40-42$ & $\mathbf{P}$ & A & G & VI & \\
\hline $2-3,120-122$ & $\mathbf{P}$ & A & G & \multirow{2}{*}{ VII } & \\
\hline $2-4,40-42$ & $\mathbf{P}$ & A & G & & \\
\hline $2-4,120-122$ & $\mathbf{P}$ & $\mathrm{C}$ & G & \multirow{3}{*}{ VIII } & \\
\hline $2-5,40-42$ & $\mathbf{P}$ & $\mathrm{C}$ & G & & \\
\hline $2-5,116-118$ & $\mathbf{P}$ & C & G & & \\
\hline $2-6,39-41$ & F & $\mathrm{F}$ & M & IX & \\
\hline $2-6,119-120$ & $\mathrm{~F}$ & $\mathrm{R}$ & $\mathbf{P}$ & & \\
\hline $2, \mathrm{CC}$ & & & MPTY & & \\
\hline
\end{tabular}

${ }^{\mathrm{a}} \mathrm{P}=$ plenty, $30-60 ; \mathrm{M}=$ mediocre, $15-30 ; \mathrm{F}=$ few, $0-15$

${ }^{\mathrm{b}} \mathrm{A}=$ abundant, $75 \%-100 \% ; \mathrm{C}=$ common, $50 \%-75 \%$;

$\mathrm{F}=$ few, $25 \%-50 \% ; \mathrm{R}=$ rare, $0 \%-25 \%$.

${ }^{\mathrm{C}} \mathrm{G}=$ good $; \mathrm{M}=$ moderate $\mathrm{P}=$ poor .

diatoms, Archaeomonadaceae and Silicoflagellatae have been compiled into a chronological chart (Table 4).

The chronological order shows the first and last occurrences of species, which can be used to divide and define the Upper Cretaceous sediments into nine biostratigraphic range zones. Good preservation and high frequency of microplanktonic siliceous fossils enabled the establishment of these zones.

\section{Pseudopyxilla jouseae Zone}

This zone is defined as the interval which starts with the first occurrence of Eunotogramma marginopunctata, Sceptroneis immaculata, and Pterotheca danica. The upper limit of this zone probably was not encountered at Site 275. Among common species of this zone are: Stephanopyxis hannai, Incisoria inordinata, I. lanceolata, Sceptroneis gracilis, S. grunowii, Hemiaulus gleseri, $H$. polycystinorum, Triceratium nobile, and Trinacria anissimowi.

\section{Acanthodiscus antarcticus Zone}

This zone starts with the first occurrence of Corbisema archangelskiana and ends with the extinction of 
TABLE 2

Ranges of Selected Siliceous Microfossil Species

\begin{tabular}{|c|c|c|c|c|c|c|c|c|c|c|c|c|c|c|c|c|c|c|c|c|c|}
\hline \multirow[b]{4}{*}{ Species } & & \multicolumn{20}{|c|}{ Sample (Interval in cm) } \\
\hline & & & 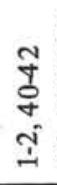 &  & & 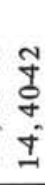 & 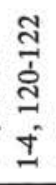 & & 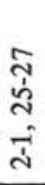 & 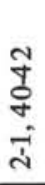 & & 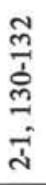 & 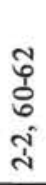 & & & &  &  & &  & 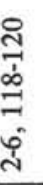 \\
\hline & Abundance $^{\mathrm{a}}$ & $\mathrm{A}$ & A & $\mathrm{C}$ & $\mathrm{C}$ & $\mathrm{C}$ & $\mathrm{C}$ & $\mathrm{A}$ & $\mathrm{A}$ & $\mathrm{A}$ & A & $\mathbf{A}$ & $\mathrm{A}$ & $\mathrm{A}$ & A $A$ & A A & A C & $\mathrm{C}$ & $\mathrm{C}$ & $\mathrm{F}$ & $\mathbf{R}$ \\
\hline & Preservation $b$ & M & G & G & G & G & G & G & G & G & G & G & G & G & G C & G G & G G & $\mathrm{G}$ & G & $\mathrm{M}$ & $\mathbf{P}$ \\
\hline \multicolumn{22}{|l|}{ BACILLARIOPHYTA } \\
\hline \multicolumn{22}{|l|}{ Bacillariophyceae (Diatomacea) } \\
\hline Acanthodiscus antarcticus n. sp. Hajós & & & $\mathrm{R}$ & $\mathrm{R}$ & $\mathbf{R}$ & & & & & & & $\mathrm{R}$ & & & & & & & A & & \\
\hline A. convexus n. sp. Hajós & & & & $\mathrm{R}$ & $\mathrm{R}$ & & & & & & & $\mathrm{C}$ & & & & & & & A & & \\
\hline A. ornatus n. sp. Hajós and Stradner & & & & & & & & & & & & $\mathrm{C}$ & & & C & & & & A & & \\
\hline Acanthodiscus sp. 1 & & & & & & & & & & & & & & & & & $\mathbf{R}$ & $\mathbf{R}$ & & & \\
\hline Acanthodiscus sp. 2 & & & $\mathrm{R}$ & & & & & & & & & & & & & & & & $\mathrm{R}$ & & \\
\hline Actinoptychus packi Hanna & & $\mathbf{R}$ & & & & & & & & & & $\mathrm{R}$ & & & & R & R & & & & \\
\hline Anaulus birostratus Grunow & & & & & $\mathbf{R}$ & & & & & & & & & & & & & & & & \\
\hline A. californicus Long, Fuge, and Smith & & & & & & & & & & & & & $\mathrm{R}$ & & & & & & & & \\
\hline A. incisus n. sp. Hajós and Stradner & & & & & $\mathbf{R}$ & & & & & & & & & & & & & & & & \\
\hline A. subantarcticus n. sp. Hajós & & & & & & & & & & & & & & & R & & & & & & \\
\hline Aulacodiscus sp. & & & & & & & & & & & & $\mathrm{R}$ & & & & & & & & & \\
\hline \multicolumn{2}{|l|}{ Biddulphia cretacea n. sp. Hajós and Stradner } & & & & & & & & & $\mathrm{R}$ & & $\mathrm{R}$ & & & $\mathrm{C}$ & & & & $\mathrm{C}$ & & \\
\hline \multicolumn{2}{|l|}{ B. sparsepunctata n. sp. Hajós } & & & & & & & & & & & & $\mathbf{R}$ & $\mathrm{R}$ & & & & & $\mathrm{C}$ & & \\
\hline \multicolumn{2}{|l|}{ Cerataulina cretacea n. sp. Hajós } & & & & & & & & & & & $\mathbf{R}$ & & $\mathrm{R}$ & & $\mathrm{R}$ & R & & $\mathbf{R}$ & & \\
\hline \multicolumn{2}{|l|}{ Creataulus sp. } & & & & & & & & $\mathrm{R}$ & & & $\mathrm{R}$ & & & & & & & & & \\
\hline \multirow{2}{*}{\multicolumn{2}{|c|}{$\begin{array}{l}\text { Chasea bicornis Hanna } \\
\text { Ch. ornata } \mathrm{n} \text {. sp. Hajós and Stradner }\end{array}$}} & & & & & & & & & A & & $\mathrm{C}$ & & $\mathbf{R}$ & & $\mathrm{C}$ & $\mathrm{C} \mathrm{C}$ & $\mathrm{C}$ & $\mathrm{R}$ & & \\
\hline & & & & & & & & & & & & & & & & & C & $R$ & & & \\
\hline \multicolumn{2}{|l|}{ Cladogramma jordanii Hanna } & $\mathrm{C}$ & & & $\mathbf{R}$ & $\mathrm{R}$ & & & & & R & $\mathrm{C}$ & & & & $\mathrm{C}$ & C & & $\mathrm{C}$ & & \\
\hline Coscinodiscus circumspectus Long, Fuge, a & and Smith & & $\mathbf{R}$ & & & & & & & $\mathbf{R}$ & & & & & & & & & & & \\
\hline C. ildicoi $\mathrm{n}$. sp. Hajós & & & & & & & & & & $\mathrm{R}$ & & & $\mathrm{R}$ & & & & & $\mathrm{R}$ & $\mathrm{R}$ & & \\
\hline C. lineatus Ehr. f. fossils Jousé & & & & & & & $\mathrm{R}$ & & & & & A & & & & & & & & & \\
\hline Coscinodiscus sp. & & & & & & & & & & & & $\mathbf{R}$ & & & & & & & & & \\
\hline Epithelion curvatum Pantocsek & & $\mathrm{R}$ & & & & & & & & & & & & $\mathrm{R}$ & & $\mathbf{R}$ & & & $\mathbf{R}$ & & \\
\hline E. russicum Pantocsek & & & & & & & & & & & & & & $\mathrm{R}$ & $\mathrm{B}$ & $\mathrm{R} R$ & $\mathbf{R}$ & & & & \\
\hline E. spinifer Pantocsek & & & & & & & & & & & & & & $\mathrm{R}$ & $\mathrm{B}$ & $\mathrm{R} R$ & R & $\mathbf{R}$ & & & \\
\hline Ethmodiscus sp. & & & & & & & & & & & & $\mathbf{R}$ & & & & & & & & & \\
\hline Eunotogramma fueloepi $\mathrm{n}$. sp. Hajós & & & $\mathrm{C}$ & $\mathrm{C}$ & $\mathrm{C}$ & & & & & & & $\mathbf{R}$ & $\mathrm{R}$ & & & & & & & & \\
\hline E. marginopunctatum Long, Fuge, and Sm & & $\mathbf{R}$ & & $\mathrm{C}$ & $\mathrm{C}$ & & $\mathrm{R}$ & & $\mathbf{R}$ & $\mathbf{R}$ & & & $\mathbf{R}$ & & $\mathbf{R}$ & $\mathbf{R}$ & $\mathbf{R}$ & & & & \\
\hline Gladius maximum n. sp. Hajós & & & & & & & & & $\mathrm{R}$ & & & $\mathrm{R}$ & & & & & & $\mathbf{R}$ & $\mathrm{R}$ & & \\
\hline G. jouseanus n. sp. Hajós & & & $\mathbf{R}$ & $\mathrm{R}$ & $\mathbf{R}$ & & & & $\mathrm{R}$ & & & $\mathrm{R}$ & & & $\mathbf{R}$ & & & & $\mathbf{R}$ & & \\
\hline G. pacificus n. sp. Hajós and Stradner & & & & & & & & & $\mathbf{R}$ & & & $\mathrm{C}$ & & & C & & & & $\mathbf{R}$ & & \\
\hline G. pacificus n. sp. f. minor n. f. Hajós & & & & $\mathrm{R}$ & $\mathrm{R}$ & & & & $\mathrm{R}$ & & & $\mathrm{C}$ & & & & & $\mathrm{C}$ & $\mathrm{C}$ & $\mathrm{C}$ & & \\
\hline G. speciosus Schulz & & & & & & & & & $\mathrm{R}$ & & & $\mathbf{R}$ & & & & & & & $\mathbf{R}$ & & \\
\hline Goniothecium odontella Ehrenberg & & & & & & & & & & & & $\mathrm{C}$ & & & & & & & $\mathbf{R}$ & & \\
\hline G. odontella Ehr. var. danica Grunow & & & & & & & & & & & & $\mathbf{R}$ & & & & & & & & & \\
\hline Helminthopsis wornardti n. sp. Hajós & & & & & $\mathbf{R}$ & $\mathrm{R}$ & & & & & & & $\mathbf{R}$ & & $\mathrm{C}$ & & & $\mathbf{R}$ & & & \\
\hline Hemiaulus altus n. sp. Hajós & & & $\mathbf{R}$ & & & & & & $\mathrm{C}$ & & & & & & & & $\mathbf{R}$ & $\mathrm{R}$ & & & \\
\hline H. andrewsi $\mathrm{n}$. sp. Hajós & & & & & & & & & & & & & & & & & & & $\mathbf{R}$ & & \\
\hline H. curvatulus Strelnikova & & & & & & & & & & & & & & & & & & $\mathbf{R}$ & & & \\
\hline H. danicus Grunow & & $\mathrm{C}$ & & & & & & & $\mathrm{C}$ & & & $\mathbf{R}$ & & & & & & & $\mathrm{R}$ & & \\
\hline H.echinulatus Jousé & & & $\mathrm{C}$ & & & & & & & & & & & & & & & $\mathbf{R}$ & & & \\
\hline H. gleseri n. sp. Hajós & & $\mathrm{C}$ & & $\mathrm{C}$ & $\mathrm{C}$ & & $\mathrm{C}$ & & $\mathrm{C}$ & & R & $\mathrm{C}$ & $\mathbf{R}$ & & & C & $C$ & & $\mathrm{C}$ & $\mathrm{C}$ & C \\
\hline H. kondai n. sp. Hajós & & & $\mathrm{R}$ & & $\mathbf{R}$ & & & & $\mathrm{C}$ & $\mathbf{R}$ & $\mathbf{R}$ & $\mathrm{C}$ & & & & & & & & & \\
\hline H. polycystinorum Ehrenberg & & $\mathrm{C}$ & & $\mathrm{C}$ & $\mathrm{C}$ & $\mathrm{C}$ & & $\mathrm{R}$ & & & $\mathrm{R}$ & $\mathrm{C}$ & & & $\mathrm{C}$ & $\mathrm{C}$ & C & C & & $\mathrm{C}$ & $\mathrm{C}$ \\
\hline H. polycystinorum Ehr. v. brevicornis Jous & & $\mathrm{C}$ & $\mathrm{C}$ & $\mathrm{C}$ & $\mathrm{C}$ & & & & & & & $\mathrm{C}$ & & & $\mathrm{C}$ & $\mathrm{C}$ & C & $\mathbf{R}$ & $\mathrm{C}$ & $\mathrm{C}$ & \\
\hline H. polymorphus Grunow & & & & & & & & & & & & $\mathbf{R}$ & & & & $\mathbf{R}$ & R & & $\mathbf{R}$ & & \\
\hline H. prae-elegans Jousé & & & & & $\mathbf{R}$ & & & & & & & $\mathrm{R}$ & & & & & $\mathrm{C}$ & $\mathrm{C}$ & $\mathrm{C}$ & & \\
\hline H. schmidti n. sp. Hajós & & & & & & & & & & & & $\mathrm{C}$ & & & & & & $\mathbf{R}$ & & & \\
\hline Horodiscus rugosus n. sp. Hajós & & & & & & & & & & & & & & & & & & & $\mathbf{R}$ & & \\
\hline Huttonia antiqua n. sp. Hajós & & & & $\mathbf{R}$ & $\mathrm{C}$ & & & & & & & $\mathbf{R}$ & & & & & & & & & \\
\hline H. punctata $\mathrm{n}$. sp. Hajós and Stradner & & & & & $\mathbf{R}$ & & & & & & & & & & R & & & & & & \\
\hline
\end{tabular}


TABLE 2 - Continued

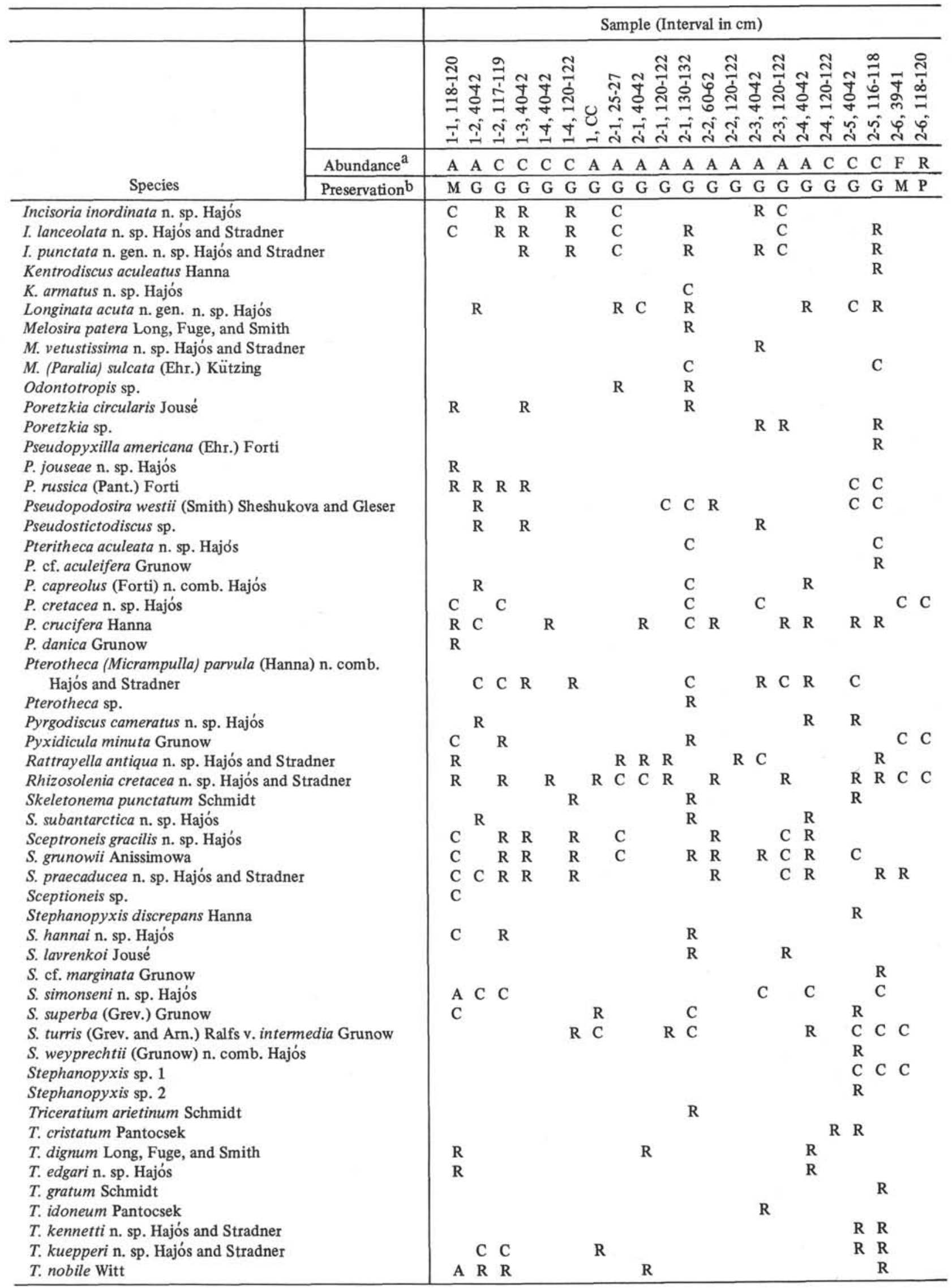


TABLE 2 - Continued

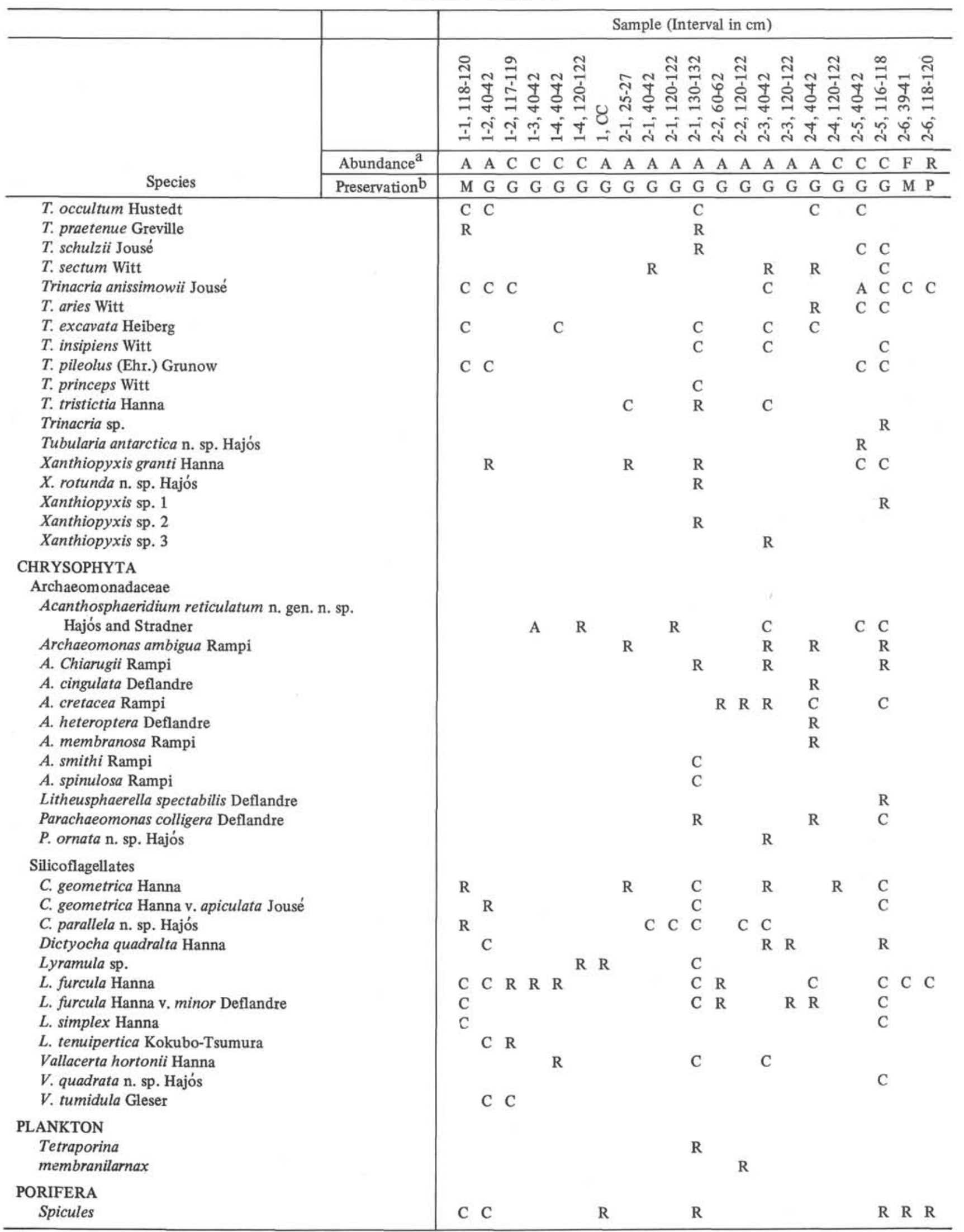

${ }^{\mathrm{a}} \mathrm{A}=$ abundant, $75 \%-100 \% ; \mathrm{C}=$ common, $50 \%-75 \% ; \mathrm{F}=$ few, $25 \%-50 \% ; \mathrm{R}=$ rare, $0 \%-25 \%$.

${ }^{\mathrm{b}} \mathrm{G}=$ good $; \mathrm{M}=$ moderate $; \mathrm{P}=$ poor. 
CRETACEOUS ARCHAEOMONADACEAE, DIATOMACEAE, SILICOFLAGELLATA

TABLE 3

Stratigraphic Ranges of Selected Siliceous Microfossils and Tentative Zonal Subdivision at Site 275

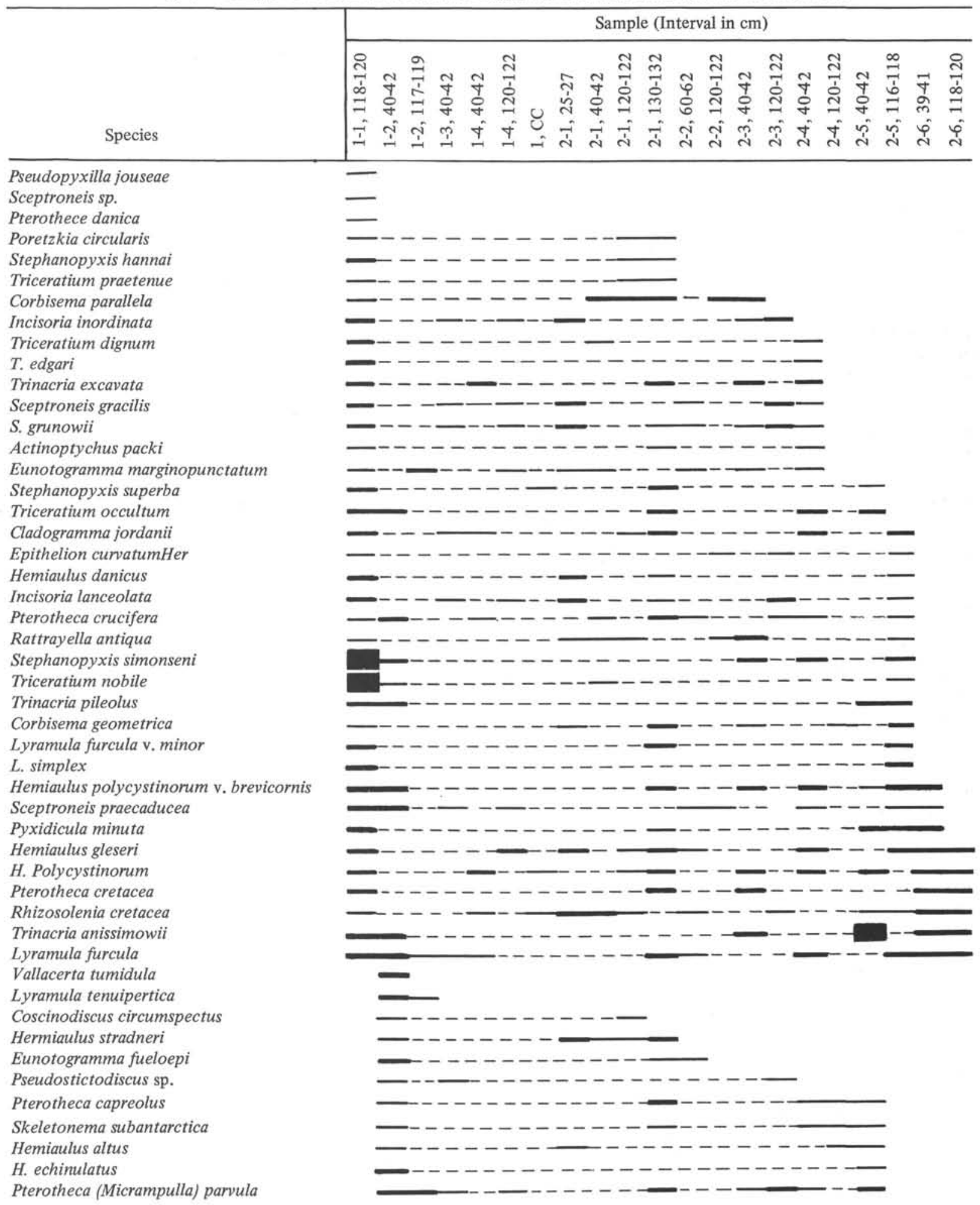




\section{HAJÓS}

TABLE 3 - Continued

\begin{tabular}{|c|c|c|c|c|c|c|c|c|c|c|c|c|c|c|c|c|c|c|c|}
\hline \multirow[b]{2}{*}{ Species } & \multicolumn{19}{|c|}{ Sample (Interval in cm) } \\
\hline &  & 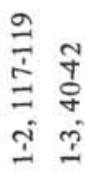 & $\begin{array}{l}\mathfrak{I} \\
\dot{+} \\
\dot{I}\end{array}$ & 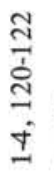 & ن &  & 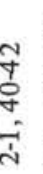 & 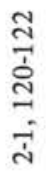 & 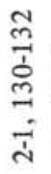 & $\begin{array}{l}\tilde{\sigma} \\
\hat{0} \\
0 \\
\hat{i} \\
\dot{\sim}\end{array}$ & 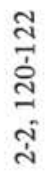 & 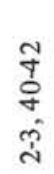 & 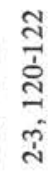 & 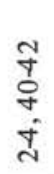 & 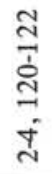 & $\begin{array}{l}\text { Ỹ } \\
\dot{y} \\
\dot{y} \\
\stackrel{\sim}{n}\end{array}$ & $\begin{array}{l}\infty \\
\vec{b} \\
= \\
\dot{d} \\
\dot{d}\end{array}$ & $\begin{array}{l}\vec{I} \\
\text { లे } \\
\dot{\nu}\end{array}$ & $\begin{array}{l}\frac{\text { d }}{\vec{b}} \\
\text { ప } \\
\dot{0} \\
\dot{0}\end{array}$ \\
\hline
\end{tabular}

Archaeomonas smithi

A. spinulosa

Stephanopyxis lavrenkoi

Acanthodiscus ornatus

Goniothecium odontella

Hemiaulus polymorphus

Pseudopodosira westii

Melosira (Paralia) sulcato

Pterotheca aculeata

Trinacria insipiens

Xanthiopyxis sp. 1

Archaeomonas chiarugii

Parachaeomonas colligera

Cerataulina cretacea

Anaulus californicus

Lyramula furcula var. minor

Biddulphia sparsepunctata

Archaeomonas cretacea]

Membranilarnax

Epithelion russicum

E. spinifer

Pterotheca

Anaulus subantarcticus

Triceratium idoneum

Xanthiopyxis sp. 3

Parachaeomonas ornata

Corbisema

Archaeomonas heteroptera

A. membranosa

Acanthodiscus sp. 1

Triceratium kennetti

Trinacria aries

Chasea ornato

Triceratium cristatum

Hemiaulus curvatulus

Stephanopyxis discrepans

$S$. weyprechtii

Tubularia antarctica

Triceratium schulzii

Hemiaulus andrewsi

Horodiscus rugosus

Kenterodiscus aculeatus

Pseudopyxilla emericana

Pterotheca cf. aculeifera

Stephanopyxis cf. marginata

Triceratium gratum

T. kennetti

Trinacria sp.

Litheusphaerella spectabilis

Vallacerta quadrata

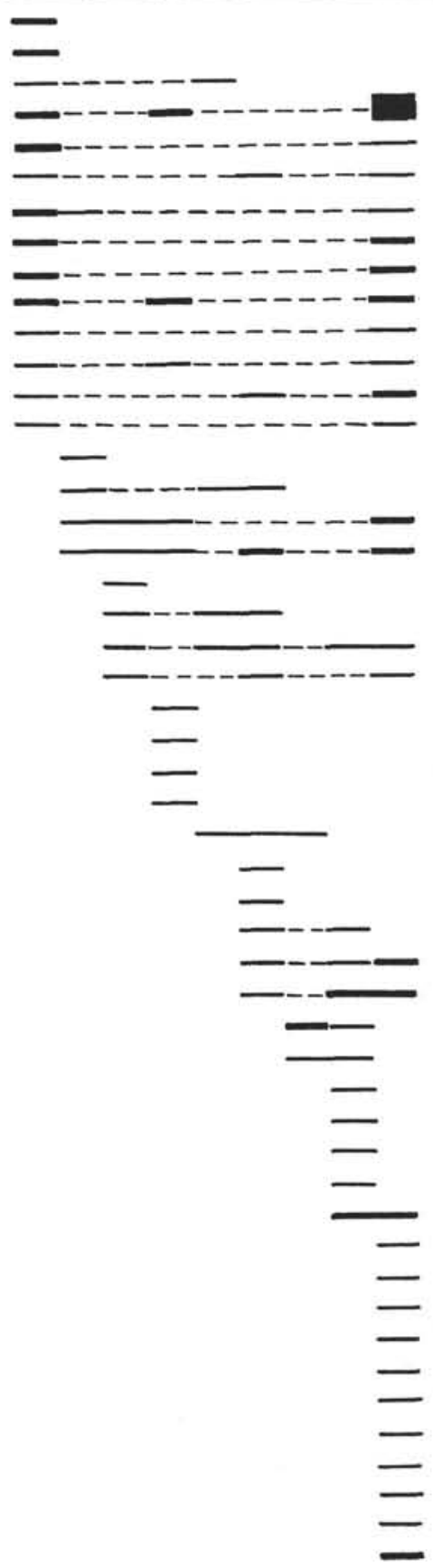


TABLE 3 - Continued

Stratigraphic Ranges of Selected Siliceous Microfossils and Tentative Zonal Subdivision at Site 275

\begin{tabular}{|c|c|c|c|c|c|c|c|c|c|c|c|c|c|c|c|c|c|c|c|c|c|}
\hline & \multicolumn{21}{|c|}{ Sample (Interval in $\mathrm{cm}$ ) } \\
\hline Species & 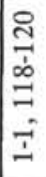 & 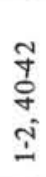 & 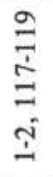 & 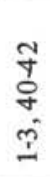 & $\begin{array}{l}\text { I } \\
\dot{y} \\
\dot{I} \\
\dot{I}\end{array}$ & 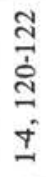 & $\begin{array}{l}0 \\
- \\
-\end{array}$ & $\begin{array}{l}\tilde{N} \\
\stackrel{\sim}{\dot{n}} \\
\dot{n}\end{array}$ & $\begin{array}{l}\stackrel{+}{y} \\
\stackrel{+}{+} \\
\overrightarrow{\dot{d}}\end{array}$ & 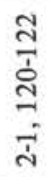 & 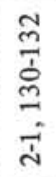 & 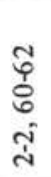 &  & $\begin{array}{l}\stackrel{\sim}{t} \\
0 \\
\dot{y} \\
\dot{\sim} \\
\dot{\sim}\end{array}$ & 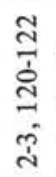 & \begin{tabular}{l}
\multirow{J}{*}{} \\
0 \\
$\dot{J}$ \\
$\dot{J}$
\end{tabular} & 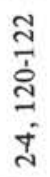 & 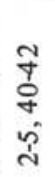 & $\begin{array}{l}\stackrel{\infty}{=} \\
\bar{b} \\
\Xi \\
\tilde{\beth} \\
\tilde{n}\end{array}$ & $\begin{array}{l}\vec{y} \\
\text { gे } \\
\text { ñ } \\
\text { cे }\end{array}$ & $\begin{array}{l}\stackrel{ }{7} \\
\stackrel{0}{\sigma} \\
\stackrel{\varphi}{\sim}\end{array}$ \\
\hline
\end{tabular}

Pyrgodiscus cameratus Acanthodiscus antarcticus Acanthodiscus sp.

Gladius jouseanus

Poretzkia sp.

Pseudopyxilla russica

Triceratium kuepperi

Xanthiopyxis granti

Longinata acuta

Corbisema geometrica v. apiculata

Dictyocha quadralta

Acanthodiscus convexus

Gladius pacificus f. minor

Huttonia punctata

Corbisema archangelskiana

Huttonia antiquu

Helminthopsis wornaidti

Hemiaulus prae-elegans

Incisoria punctata

Acanthosphaeridium reticulatum

Vallacerta hortonii

Coscinodiscus lineatus $\mathrm{f}$. fossilis

Skeletonema punctatum

Stephanopyxis turris v. intermedia

Lyramula sp.

Cerataulus sp.

Odontotropis sp.

Trinacria tristictia

Gladius maximus

G. pacificus

G. speciosus

Archaeomonas ambigua

Biddulphia cretacea

Chasea bicornis

Coscinodiscus ildicoi

Triceratium sectum

Aulacodiscus sp.

Cladogramma simplex

Coscinodiscus sp.

Ethmodiscus sp.

Hemiaulus schmidti

Kentrodiscus armatus

Melosira patera

Pterotheca sp.

Triceratium arietinum

Trinacria princeps

Xanthiopyxis rotunda

Xanthiopyxis sp. 2

Tetraporina

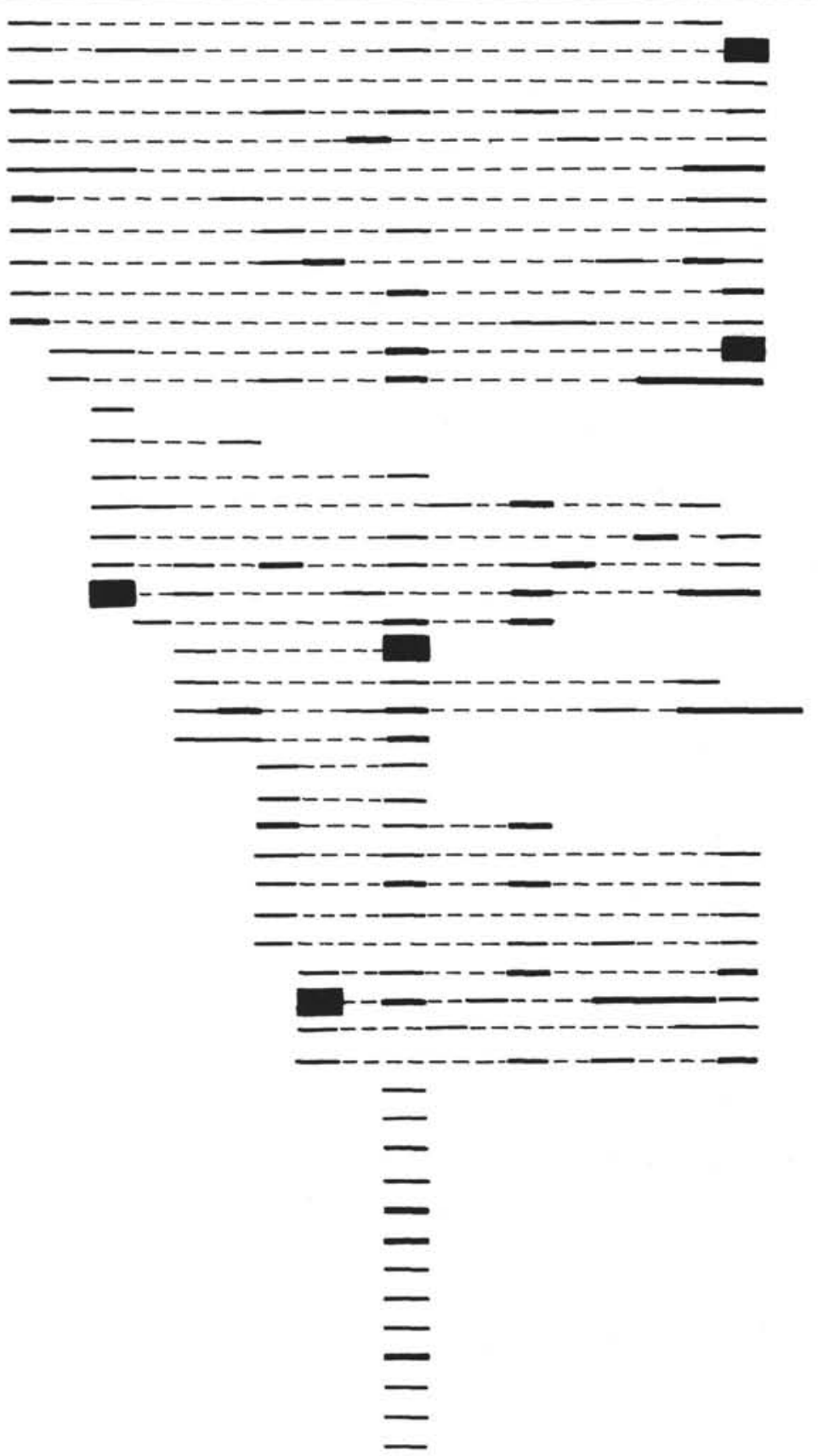


TABLE 4

Stratigraphic Occurrence of the Important Upper Cretaceous Siliceous Microfossils

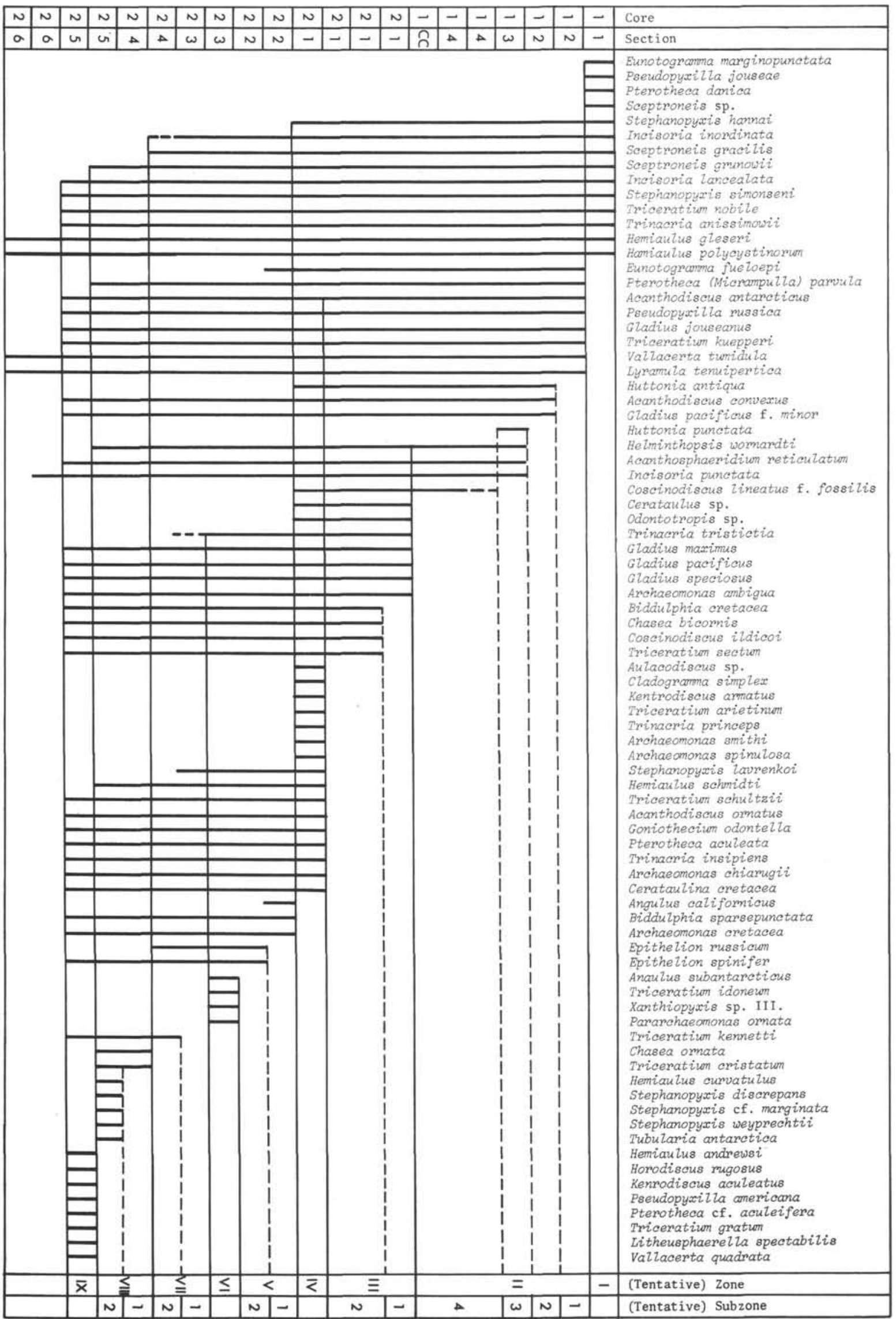


Acanthodiscus antarcticus. It can be subdivided into four subzones.

Subzone 1: The interval between the extinction of Huttonia antiqua, Acanthodiscus convexus, Gladius pacificus f. minor, and the extinction of Eunotogramma fueloepi and Pterotheca parvula.

Subzone 2: The interval between the extinction of Huttonia punctata, Helminthopsis wornardti, Acanthosphaeridium reticulatum, Incisoria punctata, and the lower boundary of Subzone 1.

Subzone 3: Defined by the first and last occurrence of Huttonia punctata. Its end is also marked by the extinction of Corbisma archangelskiana.

Subzone 4: The interval between the first occurrence of Corbisema archangelskiana and the first occurrence of Huttonia punctata.

\section{Cerataulus-Odontotropis Zone}

This Zone is the interval from the extinction of Kentrodiscus armatus, Cladogramma simplex, Triceratium arietinum to the extinction of Cerataulus sp. and Odontotropis sp. It can be divided into two subzones.

Subzone 1: The interval from the extinction of Biddulphia cretacea, Chasea bicornis, and Coscinodiscus ildicoi, to the first occurrence of Corbisema archangelskiana.

Subzone 2: The interval from the extinction of Kentrodiscus armatus, Cladogramma simplex, and Triceratium arietinum, to the extinction of Biddulphia cretacea, Chasea bicornis, and Coscinodiscus ildicoi.

\section{Kentrodiscus armatus Zone}

This zone is defined as the interval between the first and last occurrences of Triceratium sectum, Cladogramma simplex, Kentrodiscus armatus, Triceratium arietinum, Trinacria princeps, Archaeomonas smithi, and $A$. spinulosa.

\section{Biddulphia sparsepunctata Zone}

This zone is the interval between the extinction of Anaulus subantarcticus, Triceratium idoneum, and Pararchaeomonas ornata, and the extinction of Anaulus californicus and Biddulphia sparsepunctata. This zone can be divided into two subzones.

Subzone 1: The interval between the first and last occurrence of Anaulus californicus.

Subzone 2: The interval from the extinction of Anaulus subantarcticus, Triceratium idoneum, and Pararchaeomonas ornata to the first occurrence of Anaulus californicus and the extinction of Epithelion russicum and E. spinifer.

\section{Anaulus subantarcticus Zone}

This zone is the interval between the first and last occurrence of Anaulus subantarcticus, Triceratium idoneum, and Pararchaeomonas ornata.

\section{Epithelion russicum Zone}

This zone is the interval from the first occurrence of Epithelion russicum and Sceptroneis gracilis to the first occurrence of species which are the zonal markers of the Anaulus subantarcticus Zone. It can be divided into two subzones.

Subzone 1: Starts with the first occurrence of Stephanopyxis lavrenkoi, and ends with the first occurrence of the Anaulus Subantarcticus Zone markers.

Subzone 2: From the first occurrence of Epithelion russicum to the first occurrence of Stephanopyxis lavrenkoi.

\section{Chasea ornata Zone}

This zone can be defined as the interval from the first occurrence of Hemiaulus curvatulus, Stephanopyxis discrepans, Stephanopyxis weyprechtii and Tubularia sp., to the first occurrence of Epithelion russicum and Sceptroneis gracilis. Within this zone lie the extinctions of Hemiaulus curvatulus, Stephanopyxis discrepans, Stephanopyxis weyprechtii, and Tubularia sp. It can be divided into two subzones.

Subzone 1: Lies above these extinctions and extends to the first occurrence of Epithelion russicum.

Subzone 2: The first and last occurrence of Hemiaulus curvatulus, Stephanopyxis discrepans, Stephanopyxis weyprechtii, and Tubularia sp.

\section{Horodiscus rugosus Zone}

Only the upper boundary of this zone can be given, as the diatoms and other siliceous microfossils below Core 2 , Section 5 were partly or totally destroyed by solution. The upper boundary of the zone can be defined by the extinction of Hemiaulus andrewsi, Horodiscus rugosus, Kentrodiscus aculeatus, Pseudopyxilla americana, Pterotheca aculeifera, Triceratium gratum, and Litheusphaerella spectabilis.

A correlation of the tentative zonal ranges with other occurrences from California, Siberia, and the Ural Mountains in the USSR has, up to the present time, not been possible, as only descriptions of single outcrops were known from these areas.

\section{PALEOECOLOGY}

As the majority of the species studied disappeared as early as the Late Cretaceous, it is rather difficult to draw conclusions on paleotemperature of the sea. There are no relevant literature data available. The great variety of the assemblage and the very abundant specimen numbers, as well as some closely related species of longer-range genera (e.g. Coscinodiscus lineatus) suggest cold water, good aeration, and sedimentation controlled by currents. Currents must have been fairly slow, because most of the larger and thin-walled diatoms are also intact and well preserved. The diatoms of Core 1, Section 1, and Sample 1, CC of Site 275, i.e., of the topmost part of Unit 1, seem to indicate the influence of warmer waters, supported by the common occurrence of such species (of the genera Stephanopyxis, Triceratium, Trinacria, Hemiaulus, etc.) which reached a peak in tropical and subtropical waters during the Eocene. It should be noted, however, that these species are represented by much smaller specimens than in the Eocene. 


\section{PALEOGEOGRAPHIC DISTRIBUTION}

The short-range species presented in the tables and on the plates are presumably high-latitude forms. Although all are planktonic forms, only $50 \%$ of them could be identified with previously known Late Cretaceous species (Moreno Formation, California-Hanna, 1927, 1928, 1934; Mandra, 1968; Long et al., 1946; and Rampi, 1940: the Ural Mountains region and the $\mathrm{Ob}$ area of the USSR-Gleser, 1962, 1963, 1966; Jousé, 1949, 1951a, 1951b, 1955, 1963; Proschkina-Lavrenko, 1949; and Strelnikova, 1965, 1971: Arkhangelsk, Ananino, and Simbirsk, USSR-Pantocsek, 1886-1905.) Species described from these localities are usually considerably larger than the forms studied in this report (e.g., Gladius pacificus f. minor).

One should also consider that plankton forms are easily transported by sea currents. It is commonplace that recent planktonic diatoms, transported by currents, occur both in the Mediterranean and the North Atlantic waters of the circum-European seas. Accordingly, one may suppose the presence of a cold water, subantarctic current in the Late Cretaceous in the area of study.

\section{SUMMARY}

As shown in Tables 1-4, the samples studied are very rich in both species and specimens of siliceous microfossils. All of them are extinct. From the biostratigraphical point of view, the relatively large number of short-range species is of particular importance. Abundance of species and specimens as well as the state of preservation abruptly decreases in the Core 2, Section 6 samples. Sample 2, CC was practically empty.

It can be stated that in Core 2, (lower portion of Unit 1) the percentage of extinct, short-range species is higher, particularly so in the case of Archaeomonadaceae and Diatomaceae. Silicoflagellata have a longer range. The shape and ornamentation of diatom tests are very different from those of the Recent species, and some superficially resemble radiolarians (e.g. Pterotheca n. sp.). The great variety of species and forms and the good state of preservation especially revealed by electgron microscope photographs, indicate favorable conditions of sedimentation during the Late Campanian-Maestrichtian. Vertical distribution, abundance, appearance, and disappearance of species permitted the subdivision of Unit 1 (diatom-radiolarian ooze) into 9 biozones and 12 subzones (Table 4).

\section{SYSTEMATIC PALEONTOLOGY}

All the genera of diatoms found in the samples of Site 275 were arranged in the systematic order followed by Proschkina-Lavrenko (1949), whose descriptions have been used to identify the species. The new genera were inserted into this order according to their morphology. All the species, varieties, and forms are in alphabetical order within each genus. Descriptions are given for those species which have not been found in literature. The holotypes are deposited in the type collection of the Hungarian Geological Survey at Budapest XIV, Népstadion út 14 and in the Elmilab of the Geological Survey of Austria, Wien III, Rasumofskygasse 23.

All the diatom taxa found in the Upper Cretaceous of Site 275 belong systematically to the order of the Centrales Schutt, Mediales Jousé and Proschkina-Lavrenko. Not a single taxon was found with a raphe. Pennales apparently did not exist in Upper Cretaceous, at least in marine environment. The elongated forms of the genera Sceptroneis and Incisoria show at one of their ends a longitudinal pore, which might be considered as the beginning of a raphe.

\section{BACILLARIOPHYCEAE (DIATOMACEAE) \\ Genus MELOSIRA Agardh 1824 \\ Melosira patera Long, Fuge, and Smith, 1946 \\ (Plate 1, Figures 1, 2)}

Description: Valves corresponding to original diagnosis (p. 109, pl. 17, fig. 18) from Moreno shale in California. Upper Cretaceous. Occurrence: Sample 2-1, 130-132 cm.

\section{Melosira sparsepunctata n. sp. Hajós}

(Figure 3a, b. Holotype)

Derivation of name: sparsus (lat.) = scattered, punctatus (lat.) = scored.

Description: The single, well-preserved valve is circular and areolated similar to $M$. vetustissima; however, it does not show any reticulate ornamentation.

Dimensions: valve diameter, $25 \mu$

Holotype: Prep. 2817/1 HGS (Hungarian Geological Survey).

Type locality: DSDP Leg 29, Sample $275-2-5,116-118 \mathrm{~cm}$.

Type level: Upper Cretaceous.
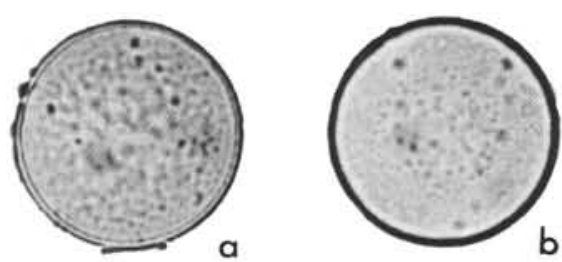

$10 \mu$

Figure 3a-b. Melosira sparsepunctata n. $s p$.

Melosira sulcata (Ehr.) Kützing (1844) var(?)

Description: The rare and poorly preserved specimens correspond to those described in Hustedt (1930, p. 276-278, fig. 118-120).

Occurrence: Sample 2-5, 116-118 cm.

Dimensions: diameter, $14 \mu-45 \mu$.

Melosira vetustissima n. sp. Hajós and Stradner

(Plate 1, Figures 9-12; Plate 18, Figures 1, 2)

Derivation of name: vetus (lat.) $=$ old.

Diagnosis and description: Circular valves, slightly convex, on the convex side ornamented with a reticulate system of radial costae and radial rows of areolae. Around each areola are ridges in peripheral direction which connect the radial ribs (costae). Near the margin they sometimes bifurcate. The central area of the valve is bare of ribs. In its center there is an irregular thickening as shown in electron photomicrograph Plate 1, Figure 12.

Dimensions: diameter, $8 \mu-16 \mu$

Holotype: Prep. 2812/1, HGS, Plate 1, Figures 9-11.

Paratype: 5069, Elmilab GSA (Geological Survey of Austria).

Type locality: DSDP Leg 29, Sample 275-2-3, 40-42 cm (holotype), Occurrence: Sample 275-2-1, 130-132 cm (paratype).

Type level: Upper Cretaceous.

Genus PSEUDOPODOSIRA Jousé, 1949

Pseudopodosira westii (W. Smith)

Sheshukova and Gleser, 1964

(Plate 1, Figures 3, 4; Plate 19, Figures 1, 2, 4)

Sheshukova-Poretzkaja and Gleser, 1964, pl. 1, fig. 4, 5. 
Description: Similar to the Paleocene forms described by Gleser; however, different from the Recent litoral Melosira westii Smith in Hustedt (1930, v. 1, p. 268-269, fig. 113).

Occurrence: Samples 2-3, 130-132 cm; 1-2, 40-42 cm.

Age: Upper Cretaceous.

\section{Pseudopodosira sp. Hajós}

(Figure 4a, b; Plate 19, Figures 3, 5)

Only one fragmentary valve with sporadical short marginal costae and distinct central area was found resembling Hyalodiscus.

Dimension: diameter, $53 \mu$; central area, $20 \mu$.

Occurrence: Sample 2-3, $40-42 \mathrm{~cm}$.
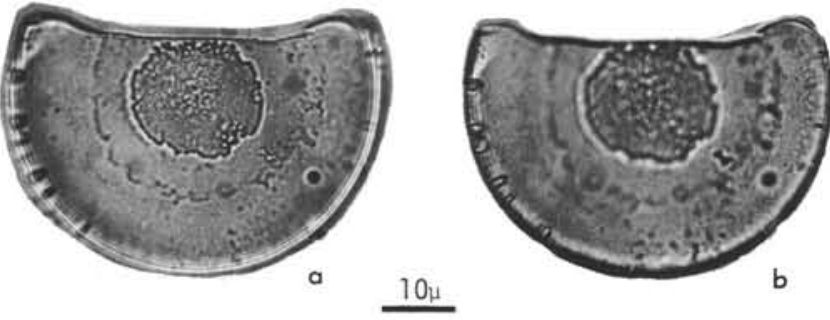

Figure 4a-b. Pseudopodosira sp. Hajós.

\section{Pseudopodosira sp. Stradner} (Plate 19, Figure 3)

Description: Circular valve with two concentrical rings of single pores. In relief similar to Pseudopodosira westii (Smith) Gleser.

Dimensions: diameter, $8 \mu$.

Occurrence: Sample 2-1, 130-132 cm.

Age: Upper Cretaceous.

\section{Genus BENETORUS Hanna, 1927 \\ Benetorus fantasmus Hanna, 1927 \\ (Plate 19, Figure 6)}

Hanna, 1927, p. 16, 19, 10.

Occurrence: Sample 2-1, 130-132 cm.

Age: Upper Cretaceous.

\section{Genus HORODISCUS Hanna, 1927 \\ Horodiscus rugosus n. sp. Hajós \\ (Plate 1, Figures 7, 8)}

Derivation of name: rugosus (lat.) = rugged.

Diagnosis and description: Circular, slightly convex valve with the marginal zone covered with roughly radially arranged fine bars and radial rows of areolae in between. The central area is covered by a system of reticulate ridges about twice as numerous as in Horodiscus macroscriptus Hanna (1927, p. 21, pl. 2, fig. 11)

Dimension: diameter, $64 \mu$; central area, $35 \mu$.

Holotype: Prep. 2817/1 HGS, Plate 1, Figures 7, 8.

Type locality: DSDP Leg 29, Sample $275-2-5,116-118 \mathrm{~cm}$.

Type level: Upper Cretaceous.

Discussion: This species can be compared to, but differs from that shown in Proschkina-Lavrenko (1949, pl. 76, fig. 7), described from Hanna (1927) as Horodiscus macroscriptus from Moreno Gulch, Fresno County, California; Upper Cretaceous.

Genus SKELETONEMA Greville, 1865

Skeletonema alternans n. sp. Stradner (Plate 20, Figure 4, Holotype)

Derivation of name: alternare (lat.) = alternate

Diagnosis and description: A Skeletonema with crown-shaped valves, which are connected with those of the adjoining cells by 10-12 interfingering extensions. These are about twice as long as wide, slightly bent inward, and formed in such a way that they fit together with those of the neighboring valve similar to a jigsaw puzzle. The margin of the valve shows a groove concentric to its periphery.
Dimensions: diameter, $11 \mu$; height of valve including extensions, $5 \mu$. Holotype: PI. 5091 Elmilab GSA.

Type locality: DSDP Leg 29, Sample 275-2-1, 130-132 cm.

Type level: Upper Cretaceous.

Skeletonema punctatum A. Schmidt, 1892

(Plate 1, Figures 5, 6; Plate 20, Figures 1, 2)

Our rare specimens correspond to those shown in Schmidt's Atlas (1874-1959, pl. 180, fig. 34) from the Upper Cretaceous of AnaninoSimbirsk, USSR.

Diameter: $20 \mu$.

Occurrence: Sample 2-1, 130-132 cm.

Age: Upper Cretaceous.

\section{Skeletonema subantarctica n. sp. Hajós \\ (Plate 2, Figure 1)}

Derivation of name: found near the Antarctic.

Diagnosis and description: The valves are convex, with long filaments inserted near the constricted margin. The filaments, which connect the frustulae to chain-colonies, are about $1 \mu$ thick and about $70 \mu$ long. They are not straight as in other species of Skeletonema with closely arranged cells, but curved in such a way that they appear tied together near the apex of each valve.

Dimensions: diameter, $12 \mu-28 \mu$; height of valve, $7 \mu-100 \mu$; length of filaments, $20 \mu-100 \mu$.

Holotype: Prep. 2800/1, HGS, Plate 2, Figure 1.

Type locality: DSDP Leg 29, Sample 275-1-2, 40-42 cm.

Type level: Upper Cretaceous.

Occurrence: Samples 275-1-2, 130-132 cm; 275-2-4, 40-42 cm (paratype).

\section{Genus PYXIDICULA Ehrenberg, 1833 \\ Pyxidicula minuta Grunow, 1884 \\ (Plate 1, Figures 16-18)}

Grunow, 1884, p. 92 , pl. 5, fig. 6 .

Occurrence: Sample 2-1, 130-132 cm.

Age: Upper Cretaceous.

\section{Genus STEPHANOPYXIS Ehrenberg, 1844 \\ Stephanopyxis discrepans Hanna, 1927 \\ (Plate 2, Figures 5, 6)}

Hanna, 1927, p. 33, pl. 4, fig. 10-11

Description: Valvae with areolae more in a random assemblage, not in rows. Diameter, approx. $30 \mu$.

Occurrence: Sample 2-5, 40-42 cm; Moreno shale, California (Hanna).

Age: Upper Cretaceous.

Stephanopyxis hannai n. sp. Hajós
(Figure 5a, b; Plate 2, Figures 9, 10)

Hanna, 1927, pl. 4, fig. 12, non St. grunowi Grove and Sturt

Derivation of name: Dedicated to the memory of George Dallas Hanna.

Diagnosis: A Stephanopyxis with areolated large margin, not hyaline, as shown by Hanna (1927). The areolae are arranged in quincunx pattern, about 3 to each $10 \mu$.

Dimension: diameter, $40 \mu-44 \mu$.

Holotype: Prep. 2799/1 HGS, Plate 2, Figures 9, 10.

Type locality: DSDP Leg 29, Sample 275-2-1, 130-132 cm.

Type level: Upper Cretaceous.

\section{Stephanopyxis lavrenkoi Jousé}

(Plate 2, Figures 2-4)

Proschkina-Lavrenko, 1949, p. 40,41, pl. 10, fig. 9a-c.

Occurrence: Samples 2-1, 130-132 cm; 2-3, 40-42 cm.

Age: Upper Cretaceous.

\section{Stephanopyxis cf. marginata Grunow, 1884}

Grunow, 1884, p. 90, pl. E. fig. 17.

Proschkina-Lavrenko, 1949, p. 39, pl. 9, fig. 7, pl. 80, fig. 1. 


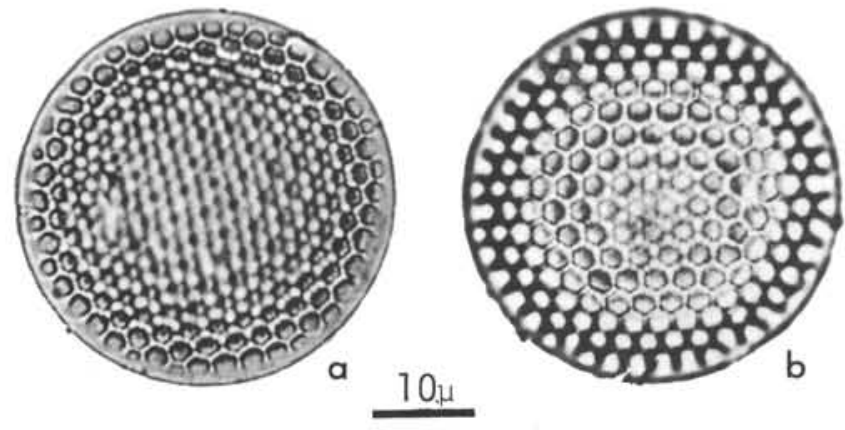

Figure 5a-b. Stephanopyxis hannai $n$. sp. Hajós.

Our specimens have 8-12 robust marginal spicules and diameters up to $65 \mu$.

Occurrence: Sample 2-5, 116-118 cm.

\section{Stephanopyxis megapora Grunow, 1884 (Plate 22, Figure 6)}

Grunow, 1884, p. 89 , pl. 5, fig. 24a,b.

Description: One small valve (diameter, $8.5 \mu$ ) with comparatively large areolae (diameter, $1.5 \mu$ ) and interstitial triangular gaps. No ultrastructure discernible within the areolae.

Occurrence: Sample 2-1, 130-132 cm.

Age: Upper Cretaceous.

\section{Stephanopyxis superba (Greville) Grunow, 1884} (Plate 2, Figures 11, 12)

Greville, 1861, p. 2, pl. 8, fig. 3-5.

Grunow, 1884, p. 91 .

Schmidt, 1874, pl. 123, fig. 5-8.

Greville, pl. 1, fig. 11.

Occurrence: Sample 2-1, 130-132 cm.

Age: Upper Cretaceous.

Stephanopyxis turris (Greville and Arnott) Ralfs in Pritcshard, 1861 (Plate 22, Figure 4; Plate 23, Figures 1-6; Plate 30, Figure 5)

Hustedt, 1927-1966, v. 1, p. 304-307, fig. 140.

Occurrence: Sample 2-1, 130-132 cm.

Stephanopyxis turris (Greville and Arnott) Ralfs var. intermedia Grunow, 1884

(Plate 1, Figures 13-15)

Grunow, 1884, p. 88, pl. 5, fig. 15, 16.

Proschkina-Lavrenko, 1949 , v. 2 , p. 40 , pl. 10, fig. 4a,b.

Occurrence: Samples 2-1, 130-132 cm; 2-5, 40-42 cm; 2-5, 116-118 $\mathrm{cm}$.

Age: Upper Cretaceous.

\section{Stephanopyxis simonseni n. sp. Hajós (Plate 2, Figures 7, 8, Holotype)}

Derivation of name: In honor of Reimer Simonsen, Institut fur Meeresforschung, Bremerhaven, West Germany.

Diagnosis: A Stephanopyxis with areolae arranged in tangential rows. Towards their margin the areolae appear to decrease in size, 5-6 areolae for each $10 \mu$, near the center they are in quincunx pattern.

Dimensions: diameter, $27 \mu-45 \mu$; wall, $2 \mu-3 \mu$ thick; height varying, as complete cells are occasionally composed of differently vaulted valves (compare Plate 30, Figure 5).

Holotype: Prep. 2800/1 HGS.

Type locality: DSDP Leg 29, Sample 275-1-2, 40-42 cm.

Type level: Upper Cretaceous.

Occurrence: Samples 2-3, 40-42 cm; 2-4, 40-42 cm; 2-5, 116-118 cm.

Stephanopyxis weyprechtii (Grunow) n. comb. Hajós (Plate 22, Figures 1, 2, 5)

Grunow, 1884, p. 92, pl. 5, fig. 5 (Pyxidicula weyprechtii)
Species designation on account of size of pores, with transfer into the genus Stephanopyxis on account of ultrastructure within the areolae. Diameter of areolae, approx. $2 \mu$.

Occurrence: Samples 2-1, 130-132 cm; 2-5, 40-42 cm.

Age: Upper Cretaceous.

\section{Stephanopyxis sp. 1 Hajós}

(Figure 6a,b)

Highly vaulted valves with rather thick wall and deep areolae in quincunx pattern.

Dimensions: diameter, $22 \mu-30 \mu$.

Occurrence: Samples 2-5, 40-42 cm; 2-6, 116-118 cm.

Age: Upper Cretaceous.

\section{Stephanopyxis sp. 2 Hajós (Figure 7)}

Large, flat circular valves with hyaline border, and about 15 spicules near the margin. Approx. 3 areolae per $10 \mu$. Valve diameter over $80 \mu$. Occurrence: Sample 2-5, $40-42 \mathrm{~cm}$. Age: Upper Cretaceous.


Figure 6a-b. Stephanopyxis sp. 1 Hajós.



Figure 7. Stephanopyxis sp. 2 Hajós. 


\section{Genus COSCINODISCUS Ehrenberg 1838}

Coscinodiscus circumspectus Long,

Fuge, and Smith, 1946

(Plate 4, Figure 1)

Long, Fuge, and Smith, 1946, p. 102, pl. 15, fig. 12.

Occurrence: Samples 1-2, 40-42 cm; 2-1, 40-42 cm (rare).

Coscinodiscus ildicoi n. sp. Hajós

(Plate 3, Figures 4, 5, Holotype)

Non C. stellaris Roper, 1858, described in Hustedt (1930, p. 396-398, fig. 207).

Derivation of name: Dedicated with thanks to Mrs. Ildiko Mihály, HGS

Diagnosis and description: A conscinodiscus with circular, slightly convex valves, which are areolated similar to $C$. stellaris Roper; however, the areolae are bundled to form sectors. The center of the valve is irregular, with a small hyaline spot, and situated where the central parts of the sectors of areolae meet. The margin is decorated with seven small spicules.

Dimensions: diameter, $58 \mu ; 6-7$ areolae per $10 \mu$ in center; 10 areolae per $10 \mu$ near the margin.

Holotype: Prep. 2816/1 HGS.

Type locality: DSDP Leg 29, Sample 275-2-5, $40-42 \mathrm{~cm}$.

Type level: Upper Cretaceous.

Occurrences: Samples 2-1, 40-42 cm; 2-2, 60-62 cm; 2-5, 40-42 cm; 2-5, 116-118 cm.

Discussion: Coscinodiscus stellaris Roper, 1858, differs from C. ildicoi $\mathrm{n}$. sp. by having smaller areolae, and not having marginal spicules.

\section{Coscinodiscus lineatus Ehrenberg}

forma fossilis Jousé, 1963

(Plate 3, Figures 1-3, Plate 38, Figure 1)

Jousé, 1963, p. 98, fig. 4, pl. 8, fig. 1-3.

Occurrence: Sample 2-1, 130-132 cm (rather common).

Age: Upper Cretaceous

Coscinodiscus morenoensis Hanna, 1927

(Plate 3, Figures 6, 7; Plate 4, Figure 2;

Plate 24, Figures 1-3; Plate 25, Figures 1-5)

Hanna, 1927, p. 18, pl. 2, fig. 3, 4 .

Description: In some of our specimens there are fewer sectors (fascicules of areolae) than originally described. The electronmicrographs show the margins of the areolae to be rosette-shaped. The bottom of the areolae has a circular pore (Plate 25). The asymmetrical central pore is elongate, and lies next to a hyaline central spot.

Occurrence: Sample 2-1, 130-132 cm.

Age: Upper Cretaceous.

\section{Genus ETHMODISCUS Castracane, 1886 \\ Ethmodiscus sp. Hajós \\ (Plate 4, Figures 3, 4)}

Description: Circular, slightly convex disc with finely radially perforated margin, and irregular punctures in the central part. No distinct boundary between margin and central area.

Dimensions: diameter, $55 \mu$; distance between dots, approx. $1 \mu$.

Occurrence: Sample 2-1, 130-132 cm.

\section{Genus XANTHIOPYXIS Ehrenberg, 1845}

Xanthiopyxis granti Hanna

(Plate 4, Figures 16, 17; Plate 26,

Figures 4, 5; Plate 35, Figure 7)

Hanna, 1927 , p. 39 , pl. 5, fig. $13,14$.

Description and discussion: The surface of the elongate valvae is decorated by a system of pores and surrounding ridges, each pore forming a small crater with an elevated center (Plate 26, Figure 5). The large polyhedral central pore is accompanied by an eccentric elongate pore. The lateral parts of the valve also have pores and craters; the margin is serrate (Plate 26, Figure 4). Related to the Biddulphinae?

Dimensions: length, $23 \mu$; width, $8 \mu$.

Occurrence: Sample 2-1, 130-132 cm.

Age: Upper Cretaceous.

\section{Xanthiopyxis rotunda n. sp. Hajós}

(Figure 8a,b; Holotype)

Derivation of name: rotundus (lat.) $=$ round.

Diagnosis: Circular lid of permanent spore. The cupular disc is ornamented with various spines and spicules.

Dimensions: diameter, $18 \mu ; 5-6$ spicules per each $10 \mu$.

Holotype: Prep. 2809/1 HGS.

Type locality: DSDP Leg 29, Sample 275-2-1, 130-132 cm.

Type level: Upper Cretaceous.

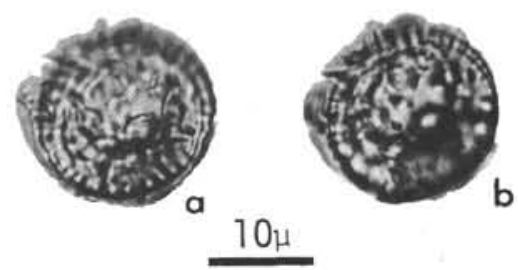

Figure 8a-b. Xanthiopyxis rotunda n. sp. Hajós.

\section{Xanthiopyxis sp. 1 Hajós}

(Plate 4, Figure 13)

Broadly lanceolate valve of a permanent spore, sparsely covered with small spicules.

Dimensions: length, $28 \mu$; width $13 \mu$.

Occurrence: Sample 2-5, 116-118 cm (rare).

\section{Xanthiopyxis sp. 2 Hajós \\ (Plate 4, Figure 12)}

An elongate, curved Xanthiopyxis decorated with long spines, and cristae.

Dimensions: length, $30 \mu$; width $12 \mu$.

Occurrence: Sample 2-1, 130-132 cm.

\section{Xanthiopyxis sp. 3 Hajós \\ (No illustration)}

Elongate, rounded, with $2 \mu-5 \mu$ long spines round the margin. Surface of the valve is rugose.

Dimensions: length $70 \mu$; width, $22 \mu$.

Occurrence: Sample 2-3, $40-42 \mathrm{~cm}$.

Age: Upper Cretaceous:

\section{Genus PORETZKIA Jousé, 1949}

Poretzkia circularis Jousé, 1949

(Plate 4, Figures 5, 6)

Proschkina-Lavrenko, 1949 , v. 2 , p. 88 , pl. 32 , fig. 8 a, b. Dimension: $28 \mu-40 \mu$ diameter.

Occurrence: Samples 1-1, 118-120 cm; 1-3, 40-42 cm; 2-1, 130-132 $\mathrm{cm}$.

\section{Poretzkia sp. Hajós (Figure 9)}

Description: Discs with flat concentrical undulation, and very finely punctured. The circular margin appears striated with 12 striae per $10 \mu$. Dimensions: diameter, $20 \mu-30 \mu$.

Occurrence: Samples 2-3, $40-42 \mathrm{~cm} ; 2-5,116-118 \mathrm{~cm}$.

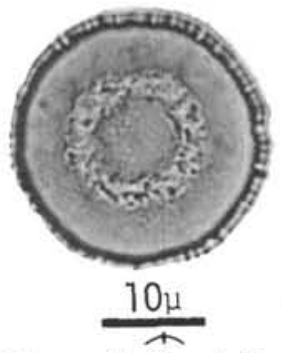

Figure 9. Poretzkia

$s p$. 
Genus CHASEA Hanna, 1934

Chasea bicornis Hanna, 1934

(Plate 5, Figures 1-3; Plate 27, Figures 3, 5, 6, ?8)

Hanna, 1934, p. 354, pl. 48, fig. 12-16.

Description: The radial striation of the central dome-shaped protuberance is best seen in the direct electron transmission (Plate 27, Figure 3); evidently the valves of permanent spores.

Occurrence: Samples 1-1, 118-120 cm; 2-1, 130-132 cm; 2-4, 40-42 $\mathrm{cm} ; 2-5,40-42 \mathrm{~cm}$; (abundant).

Chasea ornata n. sp. Hajós and Stradner

(Plate 5, Figures 4, 5; Plate 27, Figure 4)

Derivation of name: ornatus (lat.) $=$ decorated.

Diagnosis and description: Valves broadly lanceolate with rounded ends and a central protuberance. In addition to a radial striation, the valve is decorated with sparse round warts. The margin of the valve has on each side up to 20 tooth-shaped stubs.

Dimensions: length, $30 \mu-40 \mu$; width, $20 \mu-25 \mu$

Holotype: Prep. 2816/1 HGS, Plate 5, Figures 4, 5.

Paratype: Plate 27, Figure 4 (SEM)

Type locality: DSDP Leg 29, Sample 275-2-15, 40-42 cm; Paratype in Sample 275-2-1, 130-132 cm.

Type level: Upper Cretaceous.

\section{Genus CLADOGRAMMA Ehrenberg, 1854}

Cladogramma jordani Hanna, 1927

(Plate 4, Figures 9-11; Plate 20, Figure 6)

Hanna, 1927, p. 16, pl. 2, fig. 1.

Diameter: $20 \mu-24 \mu$.

Occurrence: Samples 2-1, 130-132 cm; 2-4, 40-42 cm; 2-5, 116-118 $\mathrm{cm}$; (common).

\section{Cladogramma simplex n. sp. Hajós and Stradner}

(Plate 4, Figures 7, 8; Plate 28, Figure 5)

Derivation of name: simplex (lat.) $=$ simple.

Diagnosis and description: Circular valve with vaulted center; 10-13 radial ridges are running from the margin towards the center, where they meet, and are enclosing hyaline sectors.

Dimension: diameter, $25 \mu$.

Holotype: Prep. 2809/1 HGS, Plate 4, Figures 7, 8.

Paratype: 5173 Elmilab GSA.

Type locality: DSDP Leg 29, Sample 275-2-1, 130-132 cm.

Type level: Upper Cretaceous.

\section{Genus ACTINOPTYCHUS Ehrenberg, 1841}

Actinoptychus packi Hanna, 1927

(Plate 5, Figures 23, 24; Plate 29,

Figures 1-4; Plate 30, Figures 1-4)

Hanna, 1927, p. 12, pl. 1, fig. 1-2.

Occurrence: Sample 2-1, 130-132 cm.

\section{Genus RATTRAYELLA De Toni, 1889}

Rattrayella antiqua n. sp. Hajós and Stradner

(Plate 4, Figures 14, 15; Plate 38, Figure 5)

Derivation of name: antiquus (lat.) $=$ ancient.

Diagnosis and description: Circular discs with irregular perforations all over, somewhat denser near the margin $(20-25$ per $10 \mu)$ than in the center $(10$ per $10 \mu)$. At a distance of about $3 \mu$ from the margin there is a ring of 12 or more elliptical sieve plates, with their longer axis in peripheral direction (see Plate 38, Figure 5). The pores of the sieveplates are arranged in radial rows, about 5 per $1 \mu$.

Dimensions: diamter, $55 \mu$.

Holotype: Prep. 2812/1 HGS.

Paratype: 4891 Elmilab GSA.

Type locality: DSDP Leg 29, Sample $275-2-3,40-42 \mathrm{~cm}$; paratype found in Sample 275-2-1, 130-132 cm.

Type level: Upper Cretaceous.

Discussion: This new species differs from Rattrayella oamaruensis (Grunow) De Toni in Van Heurck (1899, p. 491) by not having little spines between the sieve-plates and by not being radially striated.
Genus AULACODISCUS Ehrenberg, 1844

?Aulacodiscus sp., Hajos

(No illustration)

Large areolated valve, with areolae in tangential arrangement. Near the border are six heavy spatulate spinous processes.

Diameter: $80 \mu$.

Occurrence: Sample 2-1, 130-132 cm.

\section{Genus PYRGODISCUS Kitton, 1885 \\ Pyrgodiscus cameratus n. sp. Hajós \\ (Figure 10a,b, Holotype)}

Derivation of name: cameratus (lat.) = cambered.

Pyrgodiscus specimens similar to Pyrgodiscus triangulatus n. sp., but with more pronounced central knob, which wears the distinct $\mathrm{Y}$-mark, and about a dozen radial ridges subdividing the disc into striated sectors.

Dimension: diameter, $12 \mu-15 \mu$.

Holotype: Prep. 2814/1 HGS.

Type locality: DSDP Leg 29, Sample 275-2-4, 40-42 cm.

Occurrences: Samples 1-2, 40-42 cm; 2-4, 40-42 cm.

Type level: Upper Cretaceous.



Figure 10a-b. Pyrgodiscus cameratus n. sp. Hajós.

Pyrgodiscus sinuatus n. sp. Stradner (Plate 18, Figure 3, 4)

Derivation of name: sinus (lat.) = bay.

Diagnosis and description: A pyrgodiscus with circular discs, the margin of which is subdivided by more than a dozen semicircular bays. These are lying within a hyaline marginal zone, with only very rare pores, and are themselves perforated by two pores each. The center of the disc is either hyaline (Plate 18, Figure 3), or with reticulated ridges (Plate 18, Figure 4 ) and is surrounded by radial ridges lining deep furrows with rows of pores (approx. 4 per $10 \mu$ ). Many of the approx. 60 ridges are bifurcated.

Dimension: diameter, $8 \mu-22 \mu$.

Holotype: Prep. 2816/1, HGS.

Paratype: 4834 Elmilab GSA (Plate 18, Figures 3, 4).

Type locality: DSDP Leg 29, Sample $275-2-5,40-42 \mathrm{~cm}$. Paratype found in Sample 275-2-1, 130-132 cm.

Type level: Upper Cretaceous.

Pyrgodiscus triangulatus n. sp. Hajós and Stradner

(Figure 11a,b, Holotype; Plate 18, Figures 5, 6: Paratype)

Derivation of name: triangulatus (lat.) $=$ triangular.

Diagnosis and description: A Pyrgodiscus with circular valves, the center of which is marked by an Y-shaped, hollow elevation. About 80 radial rugulose ridges divide the disc into more or less straight furrows, in which are rows of minute circular pores (3-4 per $10 \mu)$.

Dimensions: diameter, $10 \mu-15 \mu$.

Holotype: Prep. 2816/1 HGS.

Paratype: 4844 Elmilab GSA.

Type locality: DSDP Leg 29, Sample $275-2-5,40-42 \mathrm{~cm}$. Paratype found in Sample 275-2-1, 130-132 cm.

Type level: Upper Cretaceous. 

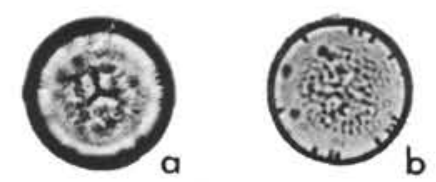

$10 \mu$

Figure 11a-b. Pyrgodiscus triangularus n. sp. Hajós and Stradner.

\section{Genus RHIZOSOLENIA Ehrenberg, 184}

Rhizosolenia cretacea n. sp. Hajós and Stradner (Plate 7, Figure 1; Plate 31, Figures 4-6)

Derivation of name: cretaceus (lat.) $=$ Cretaceous.

Diagnosis and description: Curved, tubular, siliceous bodies, which appear to be composed of compact hyaline, pillars with a network of thin stripes of perforated lamina connecting them. The basal end shows a semilunar grip, which hints that these cell elements (or cells?) were connected with something of different shape. Near this basal end, which appears compact and lacks pores, the small pores are sparsely distributed and are surrounding one elongate, larger pore. The distal end often is split up and thus proves the fasciculated structure.

Dimensions: length, $40 \mu-100 \mu$; width, $3 \mu-9 \mu$.

Pores: $4-5$ per $10 \mu$ in central part of reticulate stripes.

Holotype: Prep. 2799/1 HGS, Plate 17, Figure 1.

Paratype: 4980 Elmilab GSA (Plate 31, Figure 4).

Type locality: DSDP Leg 29, Sample 275-1-1, 118-120 cm. Paratype found in Sample 275-2-1, 130-132 cm.

Type level: Upper Cretaceous.

Discussion: This species differs from Rhizosolenia curvirostris Jousé by not being sigmoid, and also by its different fine-structure.

\section{Genus PSEUDOSTICTODISCUS Grunow, 1882}

Pseudostictodiscus sp. Hajós (Plate 5, Figure 12)

Schmidt, 1874, pl. 74, fig. 24-30.

Description: Valve broad-elliptical with two little processes at the ends of the longer axis. Perforated in radial rows.

Occurrence: Samples 1-2, 40-42 cm; 2-3, 40-42 cm; (rare).

Age: Upper Cretaceous.

\section{Genus HUTTONIA Grove and Sturt, 1887}

Huttonia antiqua n. sp. Hajós and Stradner (Plate 5, Figures 13, 14; Plate 31, Figures 1-3)

Derivation of name: antiquus (lat.) $=$ ancient

Diagnosis and description: Narrowly-elongate valves with slightly enlarged ends, somewhat twisted round the main axis. Four hyaline depressed bands subdivide the surface of the valve into a central convex field with rows of radially arranged pores about 4 per $1 \mu$, two intermediate elongate fields with rows of pores pointing to the center of the central field; and two distally inflated, cupula-shaped "ocelli" which have the appearance of oval sieves with about 7 pores per $1 \mu$. The oval sieve plate is surrounded by a $1 / 2 \mu$ hyaline zone, and in centripetal direction by a semilunar double-row of slightly larger pores.

Dimensions: length $30 \mu-90 \mu$; width, $6 \mu-8 \mu$; height, $6 \mu$.

Holotype: Prep. 2823/1 HGS, Plate 5, Figures 13, 14.

Paratype: 5238 Elmilab GSA.

Type locality: DSDP Leg 29, Sample 275-1-3, 40-42 cm. Para-type found in Sample 275-2-1, 130-132 cm.

Type level: Upper Cretaceous.

Huttonia constricta n. sp. Hajós (Figure 12a,b, Holotype)

Derivation of name: constrictus (lat.) = constricted.

Diagnosis and description: A Huttonia in general appearance similar to Huttonia antiqua n. sp., but constricted in the middle, which is smaller than the ends.

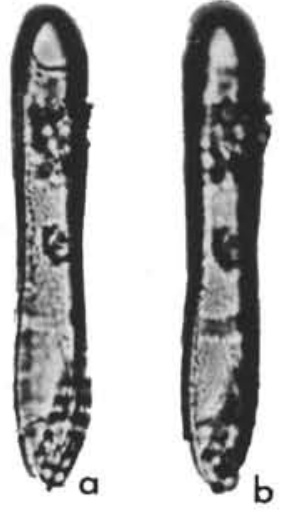

Figure 12a-b. Huttonia constricta $n . s p$. Hajós.

Dimensions: length, $50 \mu$; width, $6 \mu-8 \mu$.

Holotype: Prep. 2809/1 HGS.

Type locality: DSDP Leg 29, Sample 275-2-1, 130-132 cm.

Type level: Upper Cretaceous.

Huttonia punctata n. sp. Hajos

(Plate 5, Figures 15, 16, Holotype)

Derivation of name: punctum (lat.) $=$ dot.

Diagnosis and description: Valves lanceolate, elongate, with two transverse hyaline lines and ocelli at the end. Each ocellus is twisted with the same sense of rotation, thus if one can look on top of one ocellus, the other is averted. Surface of the valve is coarsely perforated.

Dimension: length, $30 \mu$; width, $9 \mu$.

Holotype: Prep. 2823/1 HGS.

Type locality: DSDP Leg 29, Sample 275-1-3, 40-42 cm.

Type level: Upper Cretaceous.

\section{Genus TRICERATIUM Ehrenberg, 1839}

Triceratium arietinum A. Schmidt, 1886 (Plate 8, Figures 9, 10)

Schmidt, 1874, pl. 96, fig. 19-21.

Proschkina-Lavrenko, 1949, v. 2, p. 164, pl. 61, fig. 5.

Dimension: length of side, $63 \mu$.

Occurrence: Sample 2-1, 130-132 cm.

Age: Upper Cretaceous.

\section{Triceratium cristatum Pantocsek, 1905}

(Plate 8, Figure 11, 12)

Pantocsek, 1886-1905, v. 3, p. 107, pl. 14, fig. 218.

Dimension: length of side, $55 \mu$.

Occurrence: Sample 2-5, $40-42 \mathrm{~cm}$.

Age: Upper Cretaceous.

\section{Triceratium dignum Long, Fuge, and Smith, 1946}

(Plate 8, Figures 7, 8)

Long, Fuge, and Smith, 1946, p. 113, pl. 18, fig. 10.

Dimension: length of side, $45 \mu-47 \mu$.

Occurrence: Sample 1-1, 118-120 cm.

Age: Upper Cretaceous.

Triceratium edgari n. sp. Hajós

(Plate 8, Figures 13, 14, Holotype)

Derivation of name: Named in honor of $\mathrm{N}$. Terence Edgar, Chief Scientist of the Deep Sea Drilling Project, La Jolla, California.

Diagnosis and description: Triangular valves with slightly convex sides and rounded corners. The areolae near the margin appear larger than those of the central area (approx. 5 per $10 \mu$ ).

Dimension: length of side, $17 \mu-28 \mu$.

Holotype: Prep. 2789/1 HGS.

Type locality: DSDP Leg 29, Sample $275-2-3,40-42 \mathrm{~cm}$. 
Occurrence: Sample 2-5, 116-118 cm.

Type level: Upper Cretaceous.

Triceratium gratum A. Schmidt, 1874

(Plate 8, Figures 15, 16)

Schmidt, 1874, pl. 77, fig. 19.

Description: Triangular valves with perforated apices and elongated triangular processes. Areolae arranged in radiating rows and appear elongated near margin; 2-3 central areolae.

Dimension: length of side, $60 \mu$

Occurrence: Sample 2-5, 116-118 cm.

Age: Upper Cretaceous.

\section{Triceratium idoneum Pantocsek, 1905} (Plate 9, Figure 6)

Pantocsek, $1886-1905$, v. 3 , p. 91 , pl. 24 , fig. 357 .

Triceratium uralense Strelnikova, 1965a, p. 34, pl. 5, fig. 3, 4.

Dimension: length of side, $75 \mu$.

Occurrence: Sample 2-3, $40-42 \mathrm{~cm}$.

Age: Upper Cretaceous.

Triceratium kennetti n. sp. Hajós and Stradner

(Plate 7, Figures 11-15; Plate 32, Figures 1-6)

Derivation of name: Named in honor of James P. Kennett, Chief Scientist of DSDP Leg 29.

Diagnosis and description: Triangular valves with concave sides and narrowly rounded corners. Valves are decorated with radial and arcuated areolae, larger near margin and smaller near center and girdle. Each areola has a rosette-shaped grid inserted. Adjoining cells of same cell-chain may show different patterns of grids inside their areolae (Plate 32, Figure 3). Simple pores are cratered. Girdle perforated by straight rows of elongate pores in axial direction.

Dimensions: length of side, $25 \mu-35 \mu$; diameter of areolae, $0.5 \mu-1 \mu$.

Holotype: Prep. 2817/1 HGS, Plate 7, Figures 11-13.

Paratype: 4913 Elmilab GSA.

Type locality: DSDP Leg 29, Sample 275-2-5, 116-118 cm; paratype found in Sample 275-2-1, 130-132 cm.

Type level: Upper Cretaceous.

\section{Triceratium kuepperi n. sp. Hajós and Stradner (Plate 7, Figures 9, 10; Plate 33, Figure 1)}

Derivation of name: Named in honor of Heinrich Kupper, Chief Geologist, Vienna, Austria.

Diagnosis and description: Triangular valves with convexly arcuated sides and acute angles. Valve area perforated by radially arranged round or oval pores. Pores near center less than $2 \mu$; near margin, about $1 \mu$ in diameter.

Dimension: length of sides, about $28 \mu$.

Holotype: Prep. 2800/1 HGS, Plate 7, Figures 9, 10.

Paratype: 5017 Elmilab GSA.

Type locality: DSDP Leg 29, Sample 275-1-2, $40-42 \mathrm{~cm}$; paratype found in Sample 275-2-1, 130-132 cm.

Type level: Upper Cretaceous.

Discussion: Related to Triceratium dignum Long, Fuge, and Smith, 1946 (p. 113, pl. 17, fig. 15; pl. 18, fig. 10) but sides are equal in length.

\section{Triceratium nobile Witt, 1886}

(Plate 9, Figure 3)

In Schmidt, 1874, pl. 111, fig. 26-29.

Proschkina-Lavrenko, 1949, v. 2, p. 164, pl. 94, fig. 2.

Dimension: length of side, $95 \mu$.

Occurrence: Cores 275-1 and -2 (common)

Triceratium occultum Hustedt, 1930

(Plate 9, Figure 1, 2)

In Schmidt, 1874, pl. 372, fig. 6.

Dimension: length of side, $45 \mu$.

Occurrence: Sample 2-1, 120-122 cm.

\section{Triceratium praetenue Greville, 1864}

(Plate 8, Figures 5, 6)

Greville, 1861-1866, Sev. 13, p. 3, fig. 16.

Schmidt, 1874, pl. 95, fig. 20.

Dimension: length of side, $33 \mu$.

Occurrence: Samples 1-1, 118-120 cm
Triceratium schulzii Jouse, 1949

(Plate 8, Figures 1, 2; Plate 33, Figure 2)

Proschkina-Lavrenko, 1949, v. 2, p. 161, pl. 58, fig. 3a, b.

Dimension: length of side, $50 \mu$.

Occurrence: Sample 2-5, 40-42 cm (common).

\section{Triceratium sectum Witt, 1890}

(Plate 9, Figures 3, 4)

In Schmidt, 1874, pl. 150, fig. 2-4

Triceratium heibergii Grunow, in Van Heurck, 1880-1885, pl. 112, fig. 9-11.

Similar to Trinacria interlineata Long, Fuge, and Smith, 1946 (pl

19, fig. 11) from the Upper Cretaceous Moreno shale in California.

Dimension: length of side, $33 \mu$.

Occurrence: Samples 2-3, $40-42 \mathrm{~cm} ; 2-5,116-118 \mathrm{~cm}$.

Genus BIDDULPHIA Gray, 1821 emend. Van Heurck, 1885

Biddulphia cretacea n. sp. Hajos and Stradner

(Plate 5, Figures 6, 7; Plate 34, Figures 1, 2)

Derivation of name: cretaceus (lat.) $=$ Cretaceous.

Diagnosis and description: Valves elliptical with rostrate ends, two biddulphoid processes outside the focuses of the ellipse, and radially arranged round or oval pores with delicate grid (generally missing). Between the processes two convex or undulated lines separate an inner zone from the marginal zone. Central cupula elliptical in adverse direction, surmounted by a tubular spine.

Dimensions: length, $18 \mu-28 \mu$; width, $16 \mu-24 \mu$.

Holotype: Prep. 2812/1 HGS, Plate 5, Figures 6, 7.

Paratype: 5159 Elmilab GSA.

Type locality: DSDP Leg 29, Sample 275-2-1, 25-27 cm; paratype found in Sample 275-2-1, 130-132 cm; common in all samples of Core $275-2$

Type level: Upper Cretaceous.

Biddulphia sparsepunctata n. sp. Hajós

(Plate 5, Figures 8, 9 Holotype)

Derivation of name: sparse (lat.) $=$ sparsely; punctatus (lat.) $=$ dotted

Diagnosis and description: Valves asymmetrically ovate, "beanshaped," with broadly rounded ends. Two hyaline channels, converging toward the convex side, subdivide the valve into a central, vaulted area and two large processes. Surface sparsely punctuated.

Dimensions: length, $27 \mu-30 \mu$; width, $17 \mu-18 \mu$.

Holotype: Prep. 2812/1 HGS.

Type locality: DSDP Leg 29, Sample 275-2-2, 60-62 cm.

Type level: Upper Cretaceous.

Genus ODONTOTROPIS Grunow, 1884

Odontotropis sp. Hajós

(Figure 13)

Only two fragments of large spines (part of the valve) were encountered. They are not comparable with $O$. cristata Grunow, 1884, p. 59 , pl. 2 , fig. 23 or with $O$. vitrea Pantocsek, 1905 , v. 3, p. 86, pl. 38, fig. 535.

Occurrence: Samples 2-1, 25-27 cm; 2-1, 130-132 cm

Age: Upper Cretaceous.

Genus CERATAULUS Ehrenberg, 1843

Cerataulus sp. Hajós

(Figure 14)

Description: Circular valves with $1 \mu$-wide hyaline margin. Disc marked with a fine perforation. Two round, $2 \mu$-wide ocelli or large pores at margin.

Diameter: $38 \mu$

Occurrence: Sample 2-1, 130-132 cm (very rare).

Age: Upper Cretaceous.

Genus CERATAUliNA Peragallo, 1892

Cerataulina cretacea n. sp. Hajós

(Plate 10, Figures 3, 4 Holotype)

Derivation of name: cretaceas (lat.) $=$ Cretaceous. 


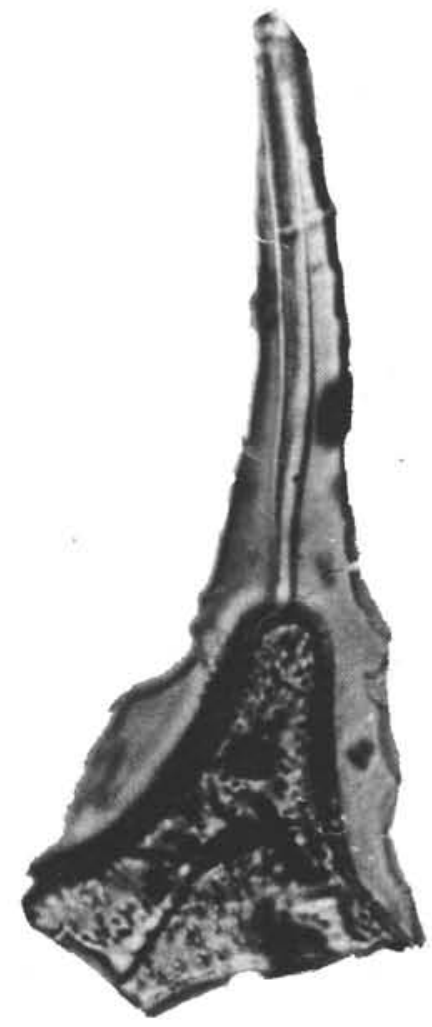

Figure 13. Odontotropis $s p$.

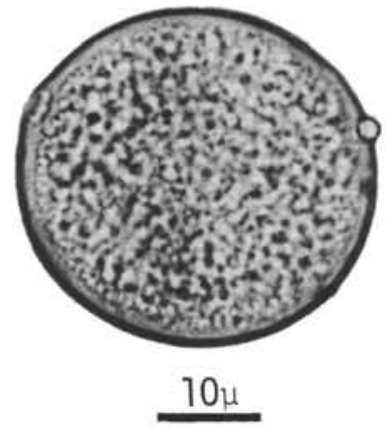

Figure 14. Cerataulus $s p$. Hajós.

Diagnosis and description: Frustula elongated, consisting of a longer cylindrical and a shorter conical part with 2-6 long filaments branching from the apex. Walls hyaline except for lower part of finely perforated cylinder.

Dimensions: diameter, $18 \mu-22 \mu$; filaments, $30 \mu-40 \mu$ long.

Holotype: Prep. 2809/1 HGS.

Type locality: DSDP Leg 29, Sample 275-2-1, 130-132 cm.

Type level: Upper Cretaceous.

Discussion: Evidently the permanent spore of a nonidentified planktonic diatom.

\section{Genus HEMIAULUS Ehrenberg, 1884 \\ Hemiaulus altus n. sp. Hajós \\ (Plate 5, Figures 17-19 Holotype)}

Derivation of name: altus (lat.) $=$ high

Diagnosis and description: A Hemiaulus with extremely high valves, height of saddle between horns exceeding diameter of basal ellipse about twice. Thin horns shorter than distance from saddle to bottom. Valve surface sparsely perforated.

Dimensions: diameter, $9 \mu$; length, $8 \mu-10 \mu$; height, $20 \mu-42 \mu$.

Holotype: Prep. 2809/1 HGS.

Type locality: DSDP Leg 29, Sample 275-1-2, 40-42 cm. Further occurrences in Samples 2-1, 25-27 cm; 2-5, 40-42 cm.

Type level: Upper Cretaceous.

Discussion: This new species is related to Hemiaulus februatus Heiberg, in Schmidt, 1874, pl. 143, fig. 44, but differs by dimension relationships.

\section{Hemiaulus andrewsi n. sp. Hajós \\ (Plate 7, Figure 8 Holotype)}

Derivation of name: named in honor of George W. Andrews, U.S. Geological Survey, Washington.

Diagnosis and description: A hemiaulus, lanceolate in valve view, longer than high. Two nearly cylindrical horns are crowned with short spines at their flat top. Areolae wide, becoming narrower near ends of horns. Transapical constrictions on both sides of valve.

Dimensions: diameter, $66 \mu$; length, $65 \mu$; height, $9 \mu-29 \mu$.

Holotype: Prep. 2817/1 HGS

Type locality: DSDP Leg 29, Sample $275-2-5,116-118 \mathrm{~cm}$.

Discussion: This species is close to Hemiaulus polycystinorum Ehrenberg, 1854, p.36, fig. 43 , but differs in horn shape.

\section{Hemiaulus curvatulus Strelnikova, 1971 (Plate 6, Figure 8)}

Strelnikova, 1971, p. 49, pl. 1, fig. 12, 13.

Dimension: length, $22 \mu$.

Occurrence: Sample 2-5, 40-42 cm (rare); Campanian strata in the USSR (Strelnikova, 1971).

Age: Upper Cretaceous.

\section{Hemiaulus danicus Grunow, 1884}

(Plate 5, Figures 10, 11)

Grunow, 1884 , p. 65 , pl. 2 , fig. 40 .

Dimension: length, $27 \mu-35 \mu$.

Occurrence: Samples 1-1, 118-120 cm; 2-1, 130-132 cm; 2-5, 116-118 $\mathrm{cm}$.

\section{Hemiaulus echinulatus Jousé, 1951}

(Plate 5, Figures 21, 22)

Jousé, 1949, p. 186, pl. 72, fig. 5 .

Jousé, 1951, p. 53, pl. 3, fig. 3a-v.

Dimensions: length, $75 \mu$; width, $15 \mu-18 \mu$.

Occurrences: Sample 1-2, 40-42 cm; Upper Cre-taceous of the northern Ural region.

Hemiaulus gleseri n. sp. Hajós

(Plate 5, Figure 20; Plate 7, Figures 6, 7 Holotype)

Derivation of name: Dedicated to S. I. Gleser, VSEGEI, Geol. Institute of Leningrad, USSR.

Diagnosis and description: Valves are in plan view lanceolated and subdivided by two transversal costae into three approximately equal parts. Low horns at ends curve inward and each wears a short spine. Valve margin is hyaline. Pores show a somewhat radial arrangement. Valve ends pointed.

Dimensions: length, $54 \mu-84 \mu$; height, $8 \mu-10 \mu$; width, $13 \mu-15 \mu$.

Holotype: Prep. 2799/1 HGS.

Type locality: DSDP Leg 29, Sample 275-1-1, 118-120 cm.

Type level: Upper Cretaceous. (Common in all studied samples of Cores 275-1 and -2.)

\section{Hemiaulus polycystinorum Ehrenberg, 1854 \\ (Plate 6, Figures 4-7; Plate 34, \\ Figure 3; Plate 35, Figures 2-5)}

Ehrenberg, 1854, p. 36, fig. 43.

Proschkina-Lavrenko, 1949, pl. 71, fig. 3a.

Hemiaulus polycystinorum var. simbirskiana Grunow, 1884, p. 65, pl. 2, fig. 44-45.

Hemiaulus antarcticus Weisse, 1854, p. 242, pl. 1, fig. 18a-f, in Schmidt, 1874 , pl. 144, fig. 28-35.

Diameter: $40 \mu-45 \mu$.

Occurrence: Cores 275-1 and -2 (common). 
Hemiaulus polycystinorum Ehrenberg

var. brevicornis Jousé, 1951

(Plate 6, Figures 1-3)

Jousé, 1951, p. 97 , pl. 5 , fig. 4,5 .

Diameter: $20 \mu-23 \mu$.

Occurrences: Samples 1-1, 118-120 cm; 2-1, 130-132 cm; 2-5, 116$118 \mathrm{~cm}$.

Age: Upper Cretaceous.

\section{Hemiaulus polymorphus Grunow, 1884}

(Plate 6, Figure 9; Plate 34,

Figure 4; Plate 35, Figure 6)

Grunow, 1884, p. 66.

Grove and Sturt, 1887, pl. 11.

Hanna, 1927, p. 20-21, pl. 2, fig. 9, 10.

Schmidt, 1874 , p. 143 , fig. $11-13,30-34$.

Diameter: $20 \mu-57 \mu$.

Discussion: A very common and rather variable species in our samples.

Occurrences: Sample 2-1, 130-132 cm; 2-5, 116-118 cm; 2-4, 40-42 $\mathrm{cm}$.

Age: Upper Cretaceous.

Hemiaulus prae-elegans Jousé, 1951

(Plate 6, Figures 12, 14)

Jousé, 1951, p. 53, pl. 3, fig. 4a,b.

Dimensions: diameter, $38 \mu$; height, $20 \mu-38 \mu$.

Occurrence: Samples 1-3, 40-42 cm; 1-4, 40-42 cm; 2-1, 130-132 cm; $2-4,40-42 \mathrm{~cm} ; 2-5,40-42 \mathrm{~cm} ; 2-5,116-118 \mathrm{~cm}$.

Age: Upper Cretaceous.

Discussion: Described from Upper Cretaceous level in Ural Mountains.

\section{Hemiaulus schmidti n. sp. Hajós}

(Plate 7, Figures 2-5)

Derivation of name: Named after A. Schmidt, who illustrated this taxon in his Atlas as "Fragliche Form".

Diagnosis and description: Valve lanceolate, elongate with rounded ends, divided by six costae into seven parts. End horns narrow, with a short spine. Valve surface finely perforated.

Dimension: length, $42 \mu-48 \mu$; width, $9 \mu$ - $10 \mu$; height, $12 \mu$.

Holotype: Prep. 2809/1 HGS, Plate 7, Figures 2, 3.

Type locality: DSDP Leg 29, Sample 275-2-1, 130-132 cm.

Type level: Upper Cretaceous.

Discussion: Illustrated by Schmidt (1874) as "Fragliche Form" (= questionable form) from Springfield, Barbadoes (pl. 144, fig. 45).

\section{Hemiaulus sporalis Strelnikova, 1971 (Plate 29, Figures 5, 6)}

Strelnikova, 1971, p. 48, pl. 3, fig. 1-10.

Occurrence: Sample 2-1, 130-132 cm.

Age: Upper Cretaceous.

Hemiaulus kondai n. sp. Hajós

(Plate 6, Figures 10, 11 Holotype)

Derivation of name: Named in honor of Józef Konda, HGS, Budapest.

Diagnosis and description: Lanceolate, elongate valves with conical diverging horns at their ends. Each horn surmounted by a spine bent in converging direction. Two nonparallel costae subdivide the valve into one short central and two longer lateral partitions, and into smaller valves with three equal partitions. Valves sparsely perforated, with short spines at their dorsal side.

Dimensions: length, $68 \mu-110 \mu$; width, $12 \mu-15 \mu$.

Holotype: Prep. 2800/1 HGS

Type locality: DSDP Leg 29, Sample 275-1-2, 40-42 cm.

Type level: Upper Cretaceous.

Discussion: A similar form was illustrated by Schmidt (1874-1959, pl. 144, fig. 44, 51, 52, 57, 58) as "Fragliche Form, n. sp?" from Springfield, Barbadoes.

Occurrence: Sample 2-1, 130-132 cm.

Age: Upper Cretaceous.

\section{Genus TRINACRIA, Heiberg, 1863}

Trinacria anissimowii Jousé, 1949

(Plate 10, Figure 2)

Proschkina-Lavrenko, 1949, p. 192, pl. 73, fig. 2.

Dimension: length of side: $35 \mu-65 \mu$.

Occurrence: Core 275-1 and -2; (common).

Age: Upper Cretaceous.

Trinacria aries Witt, 1886

(Plate 9, Figures 9-11; Plate 33, Figure 5)

Schmidt, 1874, pl. 150, fig. 14, 15.

Hanna, 1927, p. 36, pl. 5, fig. 1, 2.

Dimension: length of side, $40 \mu-65 \mu$.

Occurrences: Samples 2-4, $40-42 \mathrm{~cm} ; 2-5,40-42 \mathrm{~cm} ; 2-5,116-118$ $\mathrm{cm}$.

Age: Upper Cretaceous.

\section{Trinacria excavata Heiberg, 1863}

(Plate 10, Figure 1)

Schmidt, 1886, pl. 97, fig. 6-10.

Hanna, 1927, p. 37, pl. 5, fig. 6.

Hustedt, 1930, p. 887 , fig. 529.

Dimension: length of side $63 \mu-90 \mu$.

Occurrence: Cores 275-1 and -2 (common).

Age: Upper Cretaceous.

\section{Trinacria insipiens Witt, 1886}

(Plate 10, Figures 5, 6)

Schmidt, 1886, pl. 97, fig. 16.

Hanna, 1927, p. 37, pl. 5, fig. 7-9.

Proschkina-Lavrenko, 1949, p. 191, pl. 73, fig. 7.

Occurrence: Core 275-2 (common).

Age: Upper Cretaceous.

Trinacria pileolus (Ehrenberg) Grunow, 1884

(Plate 9, Figures 7, 8)

Grunow, 1884, p. 68 , pl. 2, fig. 59,60 .

Schmidt, 1874, pl. 97, fig. 11-14.

Dimensions: length of side, $33 \mu-45 \mu$.

Occurrences: Samples 1-1, 118-120 cm; 1-2, 40-42 cm; 2-5, 40-42 $\mathrm{cm} ; 2-5,116-118 \mathrm{~cm}$.

Age: Upper Cretaceous.

\section{Trinacria princeps Witt, 1886} (Plate 10, Figures 7, 8)

In Schmidt, 1874, pl. 110, fig. 15-17. Sample 2-1, 130-132 cm.

Proschkina-Lavrenko, 1949, p. 194, pl. 73, fig. 10.

Occurrence: Sample 1-1, 130-132 cm.

Age: Upper Cretaceous.

\section{Trinacria tristictia Hanna, 1927}

(Plate 9, Figures 5, 6)

Hanna, 1927, p. 38, pl. 5, fig. 11, 12.

Trinacria interlineata Long, Fuge, and Smith, 1946, p. 116, pl. 18, fig. 11.

Dimension: length of side, $40 \mu-80 \mu$.

Occurrences: Samples 2-1, 130-132 cm; 2-3, 40-42 cm (common). Age: Upper Cretaceous.

\section{Trinacria sp. Hajós}

(Figure 15a,b)

Description: Single specimen with concave flanks and pointed ends; surface sparsely perforated.

Dimension: length of side, $30 \mu$.

Occurrence: Sample 2-5, 116-118 cm.

Age: Upper Cretaceous.

\section{Genus GLADIUS Forti and Schulz 1932 \\ Gladius jouseanus n. sp. Hajós \\ (Plate 11, Figures 7-12)}

Derivation of name: In honor of Anastasia Jousé, Institute of Oceanography at Moscow. 


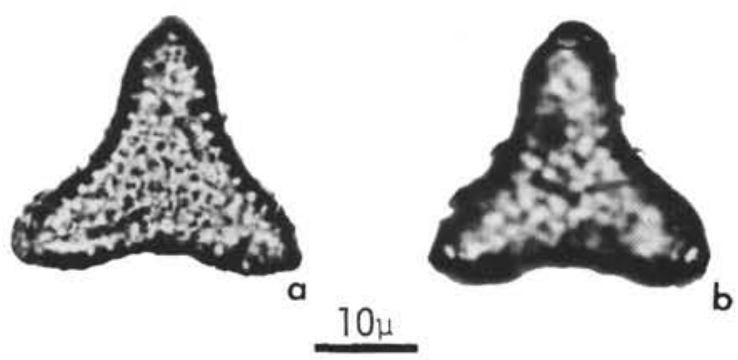

Figure 15a-b. Trinacria $s p$.

Diagnosis and description: Valves shaped like the upper part of a bowling skittle, cylindrical, with a constricted neck. Surface areolated in quincunx pattern, each areola with fine round pores inside.

Dimensions: only fragmentary cylinders found; total length, $21 \mu$ $28 \mu$; width, $10 \mu-13 \mu$; at the neck, $7 \mu-11 \mu$.

Areolae: 6 per $10 \mu$, at the end up to 10 per $10 \mu$.

Discussion: Differs from Gladius pistilliformis Jousé (1955, p. 74, 75,

fig. 2) by short neck and fine structure inside wall; much smaller.

Holotype: Prep. 2809/1 HGS, Plate 11, Figures 9, 10.

Type locality: DSDP Leg 29, Sample 275-1-2, 40-42 cm.

Type level: Upper Cretaceous.

Occurrences: Samples 2-1, 130-132 cm; 2-3, 40-42 cm.

Gladius maximus n. sp. Hajós

(Plate 11, Figure 13 Holotype)

Derivation of name: maximus (lat.) $=$ the greatest.

Diagnosis and description: Valves cylindrical with flat end and a constriction below it. Wall areolated, with hexagonal areolae decreasing in size toward flat end, and arranged in typical quincunx pattern.

Dimensions: length of cylinder, up to $130 \mu$; width, $65 \mu$; at constriction, $45 \mu$.

Areolae: 7 per $10 \mu$ at the end, $4-5$ on the cylindrical wall.

Holotype: Prep. 2809/x HGS

Type locality: DSDP Leg 29, Sample 275-2-1, 130-132 cm.

Type level: Upper Cretaceous.

Other occurrences: Samples 2-1, 25-27 cm; 2-1, 120-122 cm; 2-5, 40$42 \mathrm{~cm} ; 2-5,116-118 \mathrm{~cm}$; (up to now only encountered in Core $275-2$, Leg 29).

\section{Gladius pacificus n. sp. Hajós and Stradner}

(Plate 11, Figures 1, 2; Plate 26, Figure 2)

Derivation of name: pacificus (lat.) $=$ from the Pacific Ocean.

Diagnosis and description: Slender cylindrical tubular valves broaden conically toward the end, closed by a flat top with rather sharp rim. Areolae hexagonal, in quincunx arrangement, with irregular number of round inner pores.

Dimensions: length, $110 \mu$; width, $10 \mu-12 \mu$; at the ends, $20 \mu-30 \mu$.

Holotype: Prep. 2812/2 HGS, Plate 11, Figures 1, 2. Paratype: 4962 Elmilab GSA.

Type locality: DSDP Leg 29, Sample $275-2-3,40-42 \mathrm{~cm}$.

Type level: Upper Cretaceous.

Occurrences: Samples 2-1, 130-132 cm, to 2-5, 116-118 cm.

Discussion: Differs from other species of Gladius by sharp turn of areolated wall at the top which, in cross section, comes close to outline of equilateral triangle.

\section{Gladius pacificus n. sp. forma minor n. f. Hajós} (Plate 11, Figures 3, 4 Holotype)

Diagnosis and description: Slender, cylindrical tubular valves broaden conically toward the end, closed by a flat top. Areolae hexagonal, in quincunx arrangement.

Dimensions: height $50 \mu-90 \mu$; width, $8 \mu$; at the ends, $10 \mu-12 \mu$.

Holotype: Prep. 2809/x HGS.

Type locality: DSDP Leg 29, Sample 275-2-1, 130-132 cm.

Type level: Upper Cretaceous.

Occurrences: Samples 2-5, 40-42 cm; 2-5, 116-118 cm.

Discussion: Differs from the species G. pacificus, by being smaller, finely areolated, and constricted before the ends.
Gladius speciosus Schulz, 1935

(Plate 11, Figures 5, 6; Plate 26, Figure 3)

Schulz, 1935 , p. 3 .

Jousé, 1955 , p. 76 , fig. 4.

Dimensions: length, $56 \mu$; width, $17 \mu$.

Occurrence: Sample 2-1, 130-132 cm.

Age: Upper Cretaceous.

Genus PSEUDOPYXILLA Forti, 1909

Pseudopyxilla americana (Ehrenberg) Forti, 1909 (Plate 12, Figure 3)

Forti, 1909, pl. 1, fig. 6, 7

Proschkina-Lavrenko, 1949 , p. 200,201 , pl. 98 , fig. 4 a,b.

Occurrence: Sample 2-5, 116-118 cm.

Age: Upper Cretaceous.

\section{Pseudopyxilla jouseae n. sp. Hajós \\ (Plate 12, Figures 4, 5 Holotype)}

Jousé, 1951b, p. 59, pl. 4, fig. 4, described as Pterotheca sp. (affine carinifera Grunow).

Derivation of name: After A. Jousé, Moscow.

Diagnosis and description: Cylindrical frustula with hyaline wall, conical at one end, and extending into a long tapered spine, bifurcated at end.

Dimensions: width, $10 \mu$; height, $10 \mu$; length of spine, $28 \mu$; bifurcations, $7 \mu$.

Holotype: Prep. 2799/1 HGS.

Type locality: DSDP Leg 29, Sample 275-1-1, 118-120 cm (rare).

Type level: Upper Cretaceous.

Pseudopyxilla russica (Pantocsek) Forti, 1909

(Plate 12, Figures 1, 2; Plate 27, Figure 9)

Pantocsek, 1905, v. 3, p. 86, pl. 19, fig. 277.

Dimensions: width, $8 \mu-13 \mu$; height, $15 \mu-35 \mu$.

Occurrence: Cores $275-1$ and -2 (common).

Age: Upper Cretaceous.

\section{Genus PTEROTHECA (Grunow), Forti, 1909 \\ Pterotheca aculeata n. sp. Hajós \\ (Plate 12, Figures 10,11)}

Derivation of name: aculeus (lat.) $=$ spur.

Diagnosis and description: Valves cylindrical, about as broad as high, conical at one end, and extending into tapering spine. Walls hyaline, with cycle of short spines $(1 \mu-2 \mu)$, and short spines also sparsely distributed over the conical part.

Dimensions: width, $15 \mu$; length, $28 \mu-38 \mu$.

Holotype: Prep. 2809/1 HGS, Plate 12, Figure 11.

Paratype: Prep. 2817/1 HGS.

Type locality: DSDP Leg 29, Sample $275-2-5,116-118 \mathrm{~cm}$.

Type level: Upper Cretaceous.

Discussion: Seems to be related to the genus Kentrodiscus Pantocsek $(1889$, p. 15$)$.

\section{Pterotheca cf. aculeifera Grunow, 1880}

(Plate 12, Figure 6; Plate 28, Figures 1, 2)

Van Heurck 1880-1885, Synopsis pl. 83, fig. 13, 14.

Proschkina-Lavrenko, 1949, pl. 75, fig. $4 \mathrm{~b}$.

Dimension: diameter, $13 \mu$.

Occurrence: Sample 2-5, 116-118 cm.

Age: Upper Cretaceous.

\section{Pterotheca capreolus (Forti) n. comb. Hajós} (Plate 12, Figure 7)

Pseudopyxilla capreolus Forti (1908).

Proschkina-Lavrenko, 1949, p. 210, pl. 98, fig. 5a,b.

Diagnosis and description: Permanent spore with long branching spine, hollow only in its lowest part; compact otherwise. Transferred to the genus Pterotheca (Grunow) Forti because morphological features suggest its affiliation to Pterotheca, rather than to Pseudopyxilla. (Van Heurck, 1896, p. 430).

Dimensions: width, $13 \mu-15 \mu$; height, $40 \mu$.

Occurrence: Sample 2-1, 130-132 cm.

Age: Upper Cretaceous. 
Pterotheca cretacea n. sp. Hajós and Stradner

(Plate 12, Figures 16-18, 21; Plate 26, Figure 1)

Derivation of name: cretaceous (lat.) $=$ of Cretaceous age.

Diagnosis and description: Valves asymmetrically dumbbell-shaped. Smaller open end slightly constricted near margin; larger, more inflated end closed with a crown of spines. Larger end decorated wtih longitudinal ridges extending into the spines; numerous pores in between. Shorter, evidently proximal part of valve does not wear ridges, appears more finely dotted.

Dimension: diameter, $8 \mu-14 \mu$.

Holotype: Prep. 2799/1 HGS, Plate 12, Figures 17, 18.

Type locality: DSDP Leg 29, Sample $275-1-1,118-120 \mathrm{~cm}$.

Type level: Upper Cretaceous.

Occurrence: Cores $275-1$ and -2 (common).

Pterotheca crucifera Hanna, 1927

(Plate 12, Figures 8, 9, 22; Plate 27, Figure 7, Plate 28, Figures 3)

Hanna, 1927 , p. 30,31 , pl. 4 , fig. 5 .

Dimension: diameter, $10 \mu-23 \mu$.

Occurrence: Cores 275-1 and -2 (common).

Age: Upper Cretaceous.

\section{Pterotheca danica Grunow, 1880 \\ (No illustration)}

Proschkina-Lavrenko, 1949, p. 203, pl. 75, fig. 9.

Van Heurck, 1880-1885, Synopsis, pl. 83, fig. 7, 8 .

Dimension: diameter, $18 \mu$. Specimens are smaller than those of the Eocene.

Occurrence: Sample 1-1, 118-120 cm.

\section{Pterotheca (Micrampulla) parvula (Hanna)}

n. comb. Hajós and Stradner

(Plate 12, Figures 12-15; Plate 37, Figures 1-4)

Hanna, 1927, p. 26, pl. 3, fig. 15.

Diagnosis and description: According to our evidence, the globose part and the collar are merely the distal side of a cell, which has formed a permanent spore. The proximal part resembles Pterotheca, for which reason we propose the transfer to this genus. Deflandre (1969) has suggested a similarity to the Archaeomonadaceae; however, the ultrastructure of the wall appears to be different from the unperforatedwalls of the Archaeomonadaceae.

Dimensions: diameter, $8 \mu-20 \mu$; height, $23 \mu-40 \mu$.

Occurrences: Cores $275-1$ and -2 (common).

\section{Genus ACANTHODISCUS Pantocsek, 1892}

Acanthodiscus antarcticus n. sp. Hajós (Plate 13, Figures 1-6)

Derivation of name: found near the Antarctic.

Diagnosis and description: Valves circular, with hyaline girdle. Central part of valve convex with irregular diverging ridges, sparsely perforated.

Dimension: diameter, $35 \mu-50 \mu$.

Holotype: Prep. 2817/1 HGS, Plate 13, Figures 1-3.

Type locality: DSDP Leg 29, Sample 275-2-5, 116-118 cm.

Type level: Upper Cretaceous.

Occurrences: Samples 1-2, 40-42 cm; 2-5, 116-118 cm.

Acanthodiscus convexus n. sp. Hajós and Stradner

(Figure 16; Plate 13, Figure 8; Plate 28, Figure 6)

Derivation of name: convexus (lat.) = vaulted.

Diagnosis and description: Circular valves with the central convexity in proportion to the valve-diameter smaller than in Acanthodiscus antarcticus $\mathrm{n}$. sp. In the latter species it is larger than half the diameter, with Acanthodiscus convexus less than half the diameter or just about it. Central convexity is hyaline, without diverging ridges. Irregularly arranged ridges are confined to hyaline marginal zone.

Dimensions: diameter, $27 \mu-35 \mu$; central convexity, $10 \mu-15 \mu$.

Holotype: Prep. 2809/1 HGS, Plate 13, Figure 8.

Paratype: 5112 Elmilab GSA.

Type locality: DSDP Leg 29, Sample 275-2-1, 130-132 cm.

Type level: Upper Cretaceous.

Other occurrence: Sample 2-5, 116-118 cm (common).

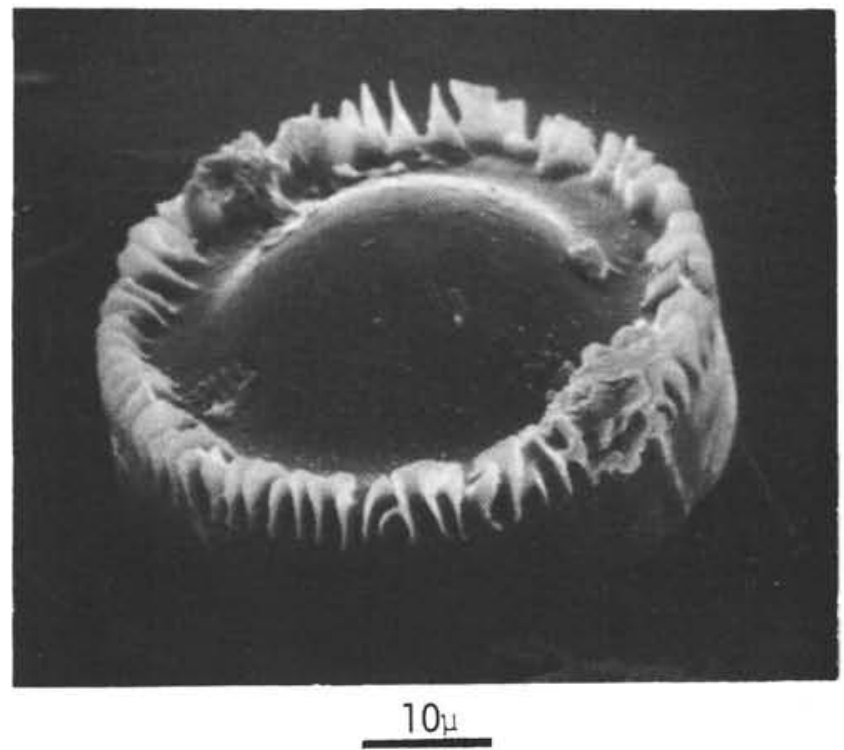

Figure 16. Acanthodiscus convexus n. sp. Hajós and Stradner.

Acanthodiscus ornatus n. sp. Hajós and Stradner (Plate 13, Figures 7, 9, 10; Plate 28, Figure 4)

Derivation of name: ornatus (lat.) $=$ decorated.

Diagnosis and description: Large, circular valves with central convexity, decorated with dense ridges and dots. Numerous irregular ridges along margin.

Dimensions: diameter, $40 \mu-55 \mu$; central part, $25 \mu-30 \mu$.

Holotype: Prep. 2812/1 HGS, Plate 13, Figures 9, 10.

Type locality: DSDP Leg 29, Sample $275-2-3,40-42 \mathrm{~cm}$. Common in all samples of Core 275-2.

Type level: Upper Cretaceous.

\section{Acanthodiscus sp. Hajós (Figure 17)}

Description: Circular valves decorated with dense, fine ridges; dots along the margin.

Diameter: $28 \mu$.

Occurrence: Samples 2-4, 40-42 cm; 2-5, 40-42 cm; (rare).

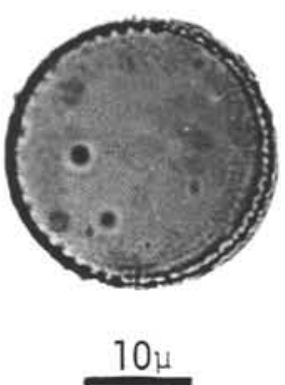

Figure 17. Acanthodiscus sp. 1 Hajós. 
Genus GONIOTHECIUM Ehrenberg, 1841

(Chaetoceros spores Ehrenberg, 1844, p. 198.)

Goniothecium odontella Ehrenberg, 1844 (Plate 10, Figures 11, 12)

Jousé, 1951, p. 60-62, pl. 5, fig. 1-7.

Proschkina-Lavrenko, 1949, p. 204, pl. 75, fig. 10a,b.

Diameter: $50 \mu-111 \mu$.

Occurrence: Samples 2-1, 130-132 cm; 2-5, 116-118 cm; (common). Age: Upper Cretaceous.

\section{Goniothecium odontella Ehrenberg}

var. danica Grunow, 1883

In Van Heurck, 1880-1885, pl. 105, fig. 11, 12.

Van Heurck, 1896, p. 428, fig. 148.

Jousé, 1951, p. 62, pl. 5, fig. 8-17.

Diameter: $30 \mu$.

Occurrence: with the species.

Age: Upper Cretaceous.

\section{Genus HELMINTHOPSIS Van Heurck, 1892}

Helminthopsis wornardti n. sp. Hajós

(Plate 13, Figure 24, Holotype)

Derivation of name: Named in honor of W. W. Wornardt, Jr., Brea, California.

Diagnosis and description: Valve elongated, lanceolate, with its dorsal side subdivided by about 14 hyaline transversal costae, therefore slightly undulated. All the higher parts of the wall are sparsely perforated.

Dimensions: length, $55 \mu-110 \mu$; width, $8 \mu$.

Holotype: Prep. 2812/1 HGS.

Type locality: DSDP Leg 29, Sample 275-2-3, 40-42 cm.

Type level: Upper Cretaceous.

Discussion: Differs from H. sokoli Hanna and Brigger, 1964, (p. 16, pl. 3 , fig. 6,7$)$, by not having inflated ends and from $H$. weissflogii Van Heurck, 1896 (p. 455, fig. 181) by not being sigmoid.

\section{Genus LONGINATA n. gen. Hajós}

Derivation of name: longus (lat.) $=$ long.

Genero-diagnosis: Frustules elongated with pointed ends bent to one side. Central part of the arch-shaped valve slightly broadened, with fewer short spines than at the ends.

Dimensions: length, $95 \mu$; width, $7 \mu$.

Genero-type: Longinata acuta n. gen. n. sp. Hajós

\author{
Longinata acuta n. sp. Hajós \\ (Plate 13, Figure 12, Holotype)
}

Derivation of name: acutus (lat.) $=$ sharp.

Diagnosis and description: See description of genero-type.

Holotype: Prep. 2800/1 HGS.

Type locality: DSDP Leg 29, Sample 275-1-2, 40-42 cm.

Type level: Upper Cretaceous.

Occurrence: Cores 275-1 and -2 (common).

\section{Genus ANAULUS Ehrenberg 1844}

Anaulus incisus n. sp. Hajós and Stradner

(Figure 18; Plate 13, Figure 23)

Derivation of name: incisus (lat.) = cut.

Diagnosis and description: Valves elongated with drop-shaped ends, two constrictions at those places where the two transversal costae subdivide it into one central part and two longer lateral parts. Surface with sparse fine dots.

Dimensions: length, $60 \mu$; width, $5 \mu$; $3 \mu$ at the ends.

Holotype: Prep. 2823/1 HGS.

Paratype: 5018 Elmilab GSA.

Type locality: DSDP Leg 29, Sample 275-1-3, 40-42 cm.

Type level: Upper Cretaceous.

Discussion: Differs from A. undulatus Long, Fuge, and Smith, 1946, the middle part of which is longer and broader than in A. incisus n. sp.

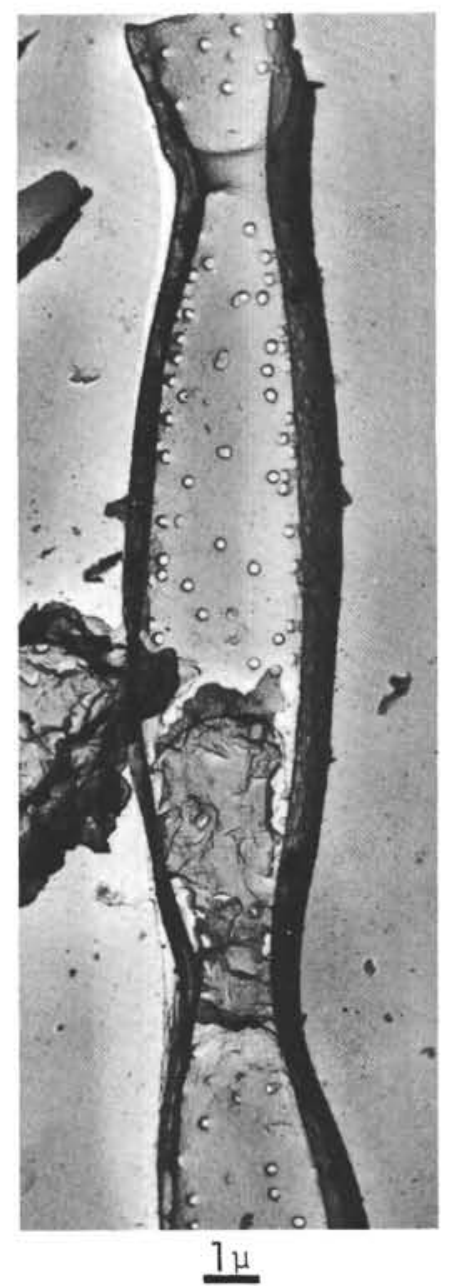

Figure 18. Anaulus incisus $n$. sp. Hajos and Stradner.

Anaulus californicus Long, Fuge, and Smith, 1946

(No illustration)

Long, Fuge, and Smith, 1946, p. 95, pl. 14, fig. 2. Occurrence: Sample 2-2, 60-62 cm.

Age: Upper Cretaceous.

Anaulus subantarcticus n. sp. Hajós (Plate 13, Figure 26, Holotype)

Derivation of name: Found near the Antarctic.

Diagnosis and description: Frustule elongated, with two transverse costae and drop-shaped ends. The flanks are straight. The two apical parts are slightly longer than the central part. Surface with fine sparse dots.

Dimensions: length, $27 \mu-48 \mu$; width, $7 \mu$.

Holotype: Prep. 2812/1 HGS,

Type locality: DSDP Leg 29, Sample 275-2-3, 40-42 cm.

Type level: Upper Cretaceous.

Discussion: Differs from $A$. birostratus Grunow in Van Heurck (1896, p. 451, fig. 179) by being smaller and thinner, and from A. incisus $\mathrm{n}$. sp. by being not constricted. 
Genus EUNOTOGRAMMA Weisse, 1854

Eunotogramma fueloepi n. sp. Hajós (Plate 13, Figure 19, Holotype)

Derivation of name: Named in honor of J. Fulöp, President of the Central Office of Geology, Budapest, Hungary.

Diagnosis and description: Elongate valves with two asymmetrically bent ends. The longer central part is round and separated from the shorter, pointed ends by transverse costae. Surface sparsely dotted.

Dimensions: length, $75 \mu$; width, $7 \mu$ in the middle, $4 \mu$ at the ends.

Holotype: Prep. 2809/1 HGS.

Type locality: DSDP Leg 29, Sample $275-2-1,130-132 \mathrm{~cm}$.

Type level: Upper Cretaceous.

Discussion: This new species differs from $E$. margino-punctatum Long, Fuge, and Smith, 1946 (pl. 16, fig. 14) which is dotted only along the margin, by its different proportions.

\section{Eunotogramma marginopunctatum \\ Long, Fuge, and Smith, 1946 (No illustration)}

Long, Fuge, and Smith, 1946, p. 106, pl. 16, fig. 14 Occurrence: Core 275-1 (common), Core 275-2 (rare).

Age: Upper Cretaceous.

\section{Genus KENTRODISCUS Pantocsek, 1889, p. 75}

Kentrodiscus aculeatus Hanna, 1927

(Plate 10, Figure 10)

Hanna, 1927, p. 22, 23, pl. 3, fig. 6 .

Diameter: $40 \mu$.

Occurrence: Sample 2-5, 116-118 cm.

Age: Upper Cretaceous.

Kentrodiscus armatus n. sp. Hajós

(Plate 10, Figure 9; Plate 12, Figures 19, 20, Holotype)

Derivation of name: armatus (lat.) $=$ armed.

Diagnosis and description: Valve cylindrical, with conical top which is terminating into a long, slightly curved spine. Conical part and spine are covered with small scattered acute spinulae $2 \mu-4 \mu$ long.

Dimensions: diameter, $18 \mu-21 \mu$.

Holotype: Prep. 2809/1 HGS.

Type locality: DSDP Leg 29, Sample 275-2-1, 130-132 cm.

Type level: Upper Cretaceous.

Discussion: Differs from $K$. aculeatus Hanna by its smaller diameter and by the many small spines.

\section{Genus SCEPTRONEIS Ehrenberg, 1844}

Sceptroneis gracilis n. sp. Hajós

(Figure 19, Holotype)

Derivation of name: gracilis (lat.) $=$ slender.

Diagnosis and description: Heteropolar elongate valves with one end headed, the other end acute. Surface finely perforated. The dots are lying in parallel lines, about 15 per $10 \mu$.

Dimensions: length, $40 \mu-78 \mu$; width, $5 \mu-6 \mu$.

Holotype: Prep. 2799/1 HGS.

Type locality: DSDP Leg 29, Sample $275-1-1,118-120 \mathrm{~cm}$.

Type level: Upper Cretaceous.

\section{Sceptroneis grunowii Anissimowa, 1937}

(Plate 11, Figures 14, 15)

Proschkina-Lavrenko, 1949, v. 2 , p. 217 , pl. 75 , fig. 13/3.

Occurrence: Sample 2-1, 130-132 cm.

Age: Upper Cretaceous.

\section{Sceptroneis praecaducea n. sp. Hajós and Stradner} (Plate 13, Figures 13, 14; Plate 36, Figures 1-4)

Derivation of name: prae (lat.) = before, caduceus (lat.) $=$ staff.

Diagnosis and description: Valves heteropolar, elongated, one end with broad heading, the other end tapering. Alternating areolae in transversal lines. Head end finely perforated like a sieve; elongated end-pore on other end.

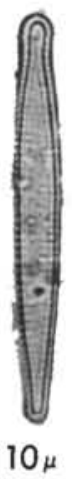

Figure 19. Sceptroneis gracilis $n$. sp. Hajós.

Dimensions: length, $65 \mu-98 \mu$; width, $3 \mu-8 \mu$.

Holotype: Prep. 2799/1 HGS, Plate 13, Figures 13, 14.

Paratype: 5179 Elmilab GSA.

Type locality: DSDP Leg 29, Sample 275-1-1, 118-120 cm.

Type level: Upper Cretaceous.

Genus TUBULARIA Brun, 1894

Tubularia antarctica n. sp. Hajós

(Figure 20, Holotype)

Derivation of name: Found near the Antarctic.

Diagnosis and description: Valves elongate with rounded ends, narrower in the middle part than at the ends. Areolae in transversal parallel lines, about 8 per $10 \mu$.

Dimensions: $55 \mu$ wide in the middle.

Holotype: Prep. 2816/1 HGS.

Type locality: DSDP Leg 29, Sample $275-2-5,40-42 \mathrm{~cm}$.

Type level: Upper Cretaceous.

Genus EPITHELION Pantocsek, 1892

Epithelion curvatum Pantocsek, 1892

(Plate 14, Figures 3, 4)

Pantocsek, 1886-1905, v. 3, p. 48, pl. 17, fig. 253.

Proschkina-Lavrenko, 1949, v. 2, p. 224, pl. 101, fig. 16.

Diameter: $18 \mu-28 \mu$.

Occurrence: Samples 1-1, 118-120 cm; 2-5, 116-118 cm.

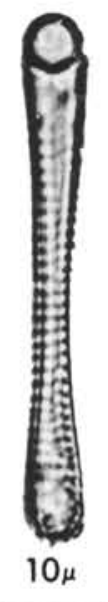

Figure 20. Tubularia antarctica n. $s p$. Hajós. 
Epithelion russicum Pantocsek, 1892

(Plate 14, Figure 2; Plate 27, Figures 1, 2)

Pantocsek, 1886-1905, v. 3, p. 48, pl. 29, fig. 424.

Proschkina-Lavrenko, 1949, v. 2, p. 224, pl. 101, fig. 17.

Diameter: $30 \mu$.

Occurrence: Sample 2-4, $40-42 \mathrm{~cm}$.

\section{Epithelion spinifer Pantocsek, 1892}

(Plate 14, Figure 1)

Pantocsek, 1886-1905, v. 3, p. 48, pl. 20, fig. 291.

Proschkina-Lavrenko, 1949, p. 224, pl. 101, fig. 18.

Dimensions: length, $50 \mu-65 \mu$; width, $25 \mu-30 \mu$.

Occurrence: Samples 2-4, 40-42 cm; 2-5, 40-42 cm.

Age: Upper Cretaceous.

\section{Genus INCISORIA n. gen. Hajós}

Derivation of name: incisus (lat.) $=$ notched.

Genero-diagnosis: Diatoms with elongate, heteropolar valves with one end rounded, the other notched or incised. Surface decorated with pores.

Genero-type: Incisoria punctata $n$. gen. n. sp. stands near the genus Sceptroneis, especially Incisoria punctata and Sceptroneis praecaducea show some common features.

\section{Incisoria punctata n. gen. n. sp. Hajós and Stradner}

(Plate 13, Figures 15, 16; Plate 36, Figure 6)

Diagnosis and description: Elongate, heteropolar valves with one end round and one end broadened, terminating with a concave notch. Middle part of the valve broadened, striated by transversal rows of pores.

Dimensions: length, $80 \mu$; width, $6 \mu-10 \mu$.

Holotype: Prep. 2809/x HGS, Plate 13, Figures 15, 16.

Paratype: 5114 Elmilab GSA.

Type locality: DSDP Leg 29, Sample 275-2-1, 130-132 cm.

Type level: Upper Cretaceous.

Occurrence: In almost all samples of Cores 275-1 and -2.

Discussion: This species differs from Sceptroneis praecaducea by its concave notch.

Incisoria inordinata n. sp. Hajós

(Plate 13, Figures 20, 21, Holotype)

Derivation of name: inordinatus (lat.) $=$ disordered.

Diagnosis and description: Elongate, heteropolar valves, one end round, the other end broadened, concave incised on the top. Surface with disordered pores. Middle part of the valve broadened.

Dimensions: length, $58 \mu-105 \mu ; 4 \mu-5 \mu$ at the middle part; $8 \mu-12 \mu$ at the concave notch.

Holotype: Prep. 2812/1 HGS.

Type locality: DSDP Leg 29, Sample 275-2-3, 40-42 cm.

Type level: Upper Cretaceous.

Occurrence: In almost all samples of Cores 275-1 and -2 .

Discussion: This new species differs from Incisoria punctata by the valves not being striated with transversal rows of pores.

Incisoria lanceolata n. sp. Hajós and Stradner (Plate 13, Figures 22, 25; Plate 36, Figure 5)

Derivation of name: lanceolatus (lat.) $=$ lance-shaped

Diagnosis and description: Elongate, heteropolar valves with one end round, the other notched. Both ends narrower than the somewhat broader middle part, with slightly convex flanks. Valves striated with transversal rows of pores.

Dimensions: length, $40 \mu-92 \mu$; width, $6 \mu-7 \mu ; 3 \mu-5 \mu$ at the ends.

Holotype: Prep. 2817/1 HGS.

Paratype: 5008 Elmilab GSA.

Type locality: DSDP Leg 29, Sample 275-2-5, 116-118 cm.

Type level: Upper Cretaceous.

Discussion: Differs from Incisoria punctata $\mathrm{n}$. $\mathrm{sp}$. by being narrower at the notched end and by its rather straight flanks.

\section{ARCHAEOMONADACEAE}

Genus ACANTHOSPHAERIDIUM n. gen. Hajós and Stradner

Derivation of name: acantha (greek) = thorn; sphaira (greek) $=$ sphere.
Genero-diagnosis: Siliceous ovoid cysts with one large pore surrounded by crooked spines about as long as or longer than cyst diameter. Cyst wall ornamented by reticulate ridges. One or two pores perforate wall of cyst between ridges.

Genero-type: Acanthosphaeridium reticulatum n. gen. n. sp. Acanthosphaeridium reticulatum, sole representative of this genus to date, is tentatively assigned to the Archaeomonadaceae. Some resemblance to the loricas of the Ebriidae, considered zooflagellates.

\section{Acanthosphaeridium reticulatum n. gen. n. sp. Hajós and Stradner \\ (Plate 14, Figures 5-11; Plate 37, Figure 6)}

Derivation of name: reticulum (lat.) $=$ net.

Diagnosis and description: Globular or ovoid cysts with large rounded pore and 3-5 heavy long spines surrounding the pore. Spine shape variable but seldom straight. Cyst surface is decorated by reticulate pattern of ridges with pores in between.

Dimensions: diameter, $8 \mu-10 \mu$; spines, $12 \mu$-14 $\mu$ long.

Holotype: Prep. 2812/1 HGS, Plate 14, Figures 5, 7.

Paratype: 4843 Elmilab GSA.

Type locality: DSDP Leg 29, Sample 275-2-3, 40-42 cm.

Type level: Upper Cretaceous.

Genus ARCHAEOMONAS Deflandre, 1932

Archaeomonas ambigua Rampi, 1940 (Plate 14, Figures 12, 13)

Rampi, 1940, p. 64, fig. 10; Deflandre, 1969, no. 4179. Occurrence: Sample 2-3, 40-42 cm.

Age: Upper Cretaceous.

Archaeomonas chiarugii Rampi, 1940

(Plate 14, Figures 14-16; Plate 39, Figure 2)

Rampi, 1940, p. 64, fig. 8; Deflandre, 1969, no. 4204. Occurrences: Samples 2-1, 130-132 cm; 1-1, 119-120 cm.

Archaeomonas cingulata Deflandre, 1938 (Figure 21a,b)

Deflandre, 1938, p. 80, fig. 18,$19 ; 1969$, no. 4205 .

Occurrence: Sample 2-4, $40-42 \mathrm{~cm}$.

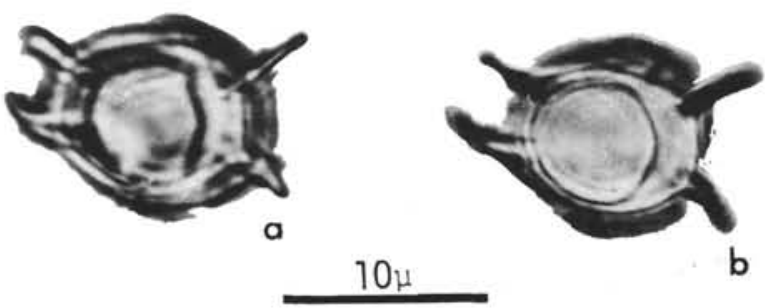

Figure 21a-b. Archaemonas cingulata Deflandre, 1938.

Archaeomonas cratera Deflandre, 1933 (Plate 39, Figure 1)

Deflandre, 1933, p. 86, fig. 24; Deflandre, 1969, no. 4214-4216. Occurrence: Sample 2-1, 130-132 cm.

Age: Upper Cretaceous.

\section{Archaeomonas cretacea Rampi, 1940}

(Plate 14, Figures 17, 18)

Rampi, 1940, p. 65, fig. 14; Deflandre, 1969, no. 4219. Occurrence: Samples 1-1, 118-120 cm; 2-5, 116-118 cm.

Archaeomonas heteroptera Deflandre, 1932

(Plate 14, Figures 19, 20)

Deflandre, 1932 , p. 349 , fig. $10-17$; 1969 , no. 4244-4250.

Occurrence: Sample 2-4, 40-42 cm.

Age: Upper Cretaceous. 
Archaeomonas membranosa Rampi, 1940

(Plate 14, Figures 21, 22)

Rampi, 1940, p. 64, fig. 15; Deflandre, 1969, no. 4278. Occurrence: Sample 2-4, 40-42 cm.

Age: Upper Cretaceous.

\section{Archaeomonas smithi Rampi, 1940}

(Plate 14, Figures 28, 29)

Rampi, 1940, p. 66, fig. 2; Deflandre, 1969, no. 4321.

Occurrence: Sample 2-1, 130-132 cm.

Age: Upper Cretaceous.

\section{Archaeomonas spinulosa Rampi, 1940}

(Plate 14, Figures 23, 24)

Rampi, 1940, p. 63, fig. 5; Deflandre, 1969, no. 4334.

Occurrence: Sample 2-1, 130-132 cm.

Age: Upper Cretaceous.

\section{Genus LITHEUSPHAERELLA Deflandre, 1932 \\ Litheusphaerella spectabilis Deflandre, 1932 \\ (Plate 14, Figures 25-27)}

Deflandre, 1932, p. 354 , fig. $34-37$; 1969, no. $4386-4393$.

Occurrence: Sample 2-5, $116-118 \mathrm{~cm}$.

Age: Upper Cretaceous.

\section{Genus PARARCHAEOMONAS Deflandre, 1932 \\ Pararchaeomonas colligera Deflandre, 1932

$$
\text { (Plate 14, Figures 30, 31) }
$$

Deflandre, 1932, p. 351 , fig. 25,$26 ; 1969$, no. $4397,4398$.

Occurrence: Samples 2-4, 40-42 cm; 2-5, 116-118 cm.

Age: Upper Cretaceous.

\section{Pararchaeomonas ornata n. sp. Hajós \\ (Plate 14, Figures 32-34, Holotype)}

Derivation of name: ornatus (lat.) = decorated.

Diagnosis and description: Globular cyst with large pore and only a

short collar. Wall structure irregularly densely granulated.

Dimensions: diameter, $10 \mu$; pore, $4 \mu$ wide; neck, $1 \mu$ high.

Holotype: Prep. 2812/1 HGS.

Type locality: DSDP Leg 29, Samples $275-2-3,40-42 \mathrm{~cm}$

Type level: Upper Cretaceous.

Genus ARTISPHAERIDIUM n. gen. Stradner

Derivation of name: artes (lat.) $=$ the fine arts.

Genero-diagnosis: Spherical cysts with surface ornamentation consisting of mushroom-shaped protrusions and large spines.

Diameter: $6 \mu$.

Genero-type: Artisphaeridium fragile n. gen. n. sp.

\section{Artisphaeridium fragile n. gen. n. sp. Stradner} (Plate 39, Figures 4-6)

Derivation of name: fragilis (lat.) $=$ fragile.

Diagnosis and description: Spherical cyst covered with hundreds of small mushroom-shaped protrusions with an irregular outline. Some standing free, others grown together. Length of 12 or more larger spines unknown, as all are missing in type-specimen.

Holotype: 5136 Elmilab GSA, Plate 39, Figure 4.

Type locality: DSDP Leg 29, Sample 275-2-1, 130-132 cm.

Type level: Upper Cretaceous.

Discussion: Litheusphaerella spectabilis Deflandre has similar mushroom-shaped protrusions which are at least twice as big and not so frequent, and is lacking spines.

\section{SILICOFLAGELLATAE}

Genus CORBISEMA Hanna, 1928

Corbisema geometrica Hanna, 1928

(Plate 15, Figure 1)

Hanna, 1928, p. 261, pl. 41, fig. 1, 2.

Occurrence: Sample 2-5, $116-118 \mathrm{~cm}$.

Age: Upper Cretaceous.
Corbisema geometrica Hanna

var. apiculata Jouse, 1949

(Plate 15, Figures 2, 3, 5)

In Jousé, 1951b, p. 63, pl. 6, fig. 2; Loeblich et al., 1968, p. 76, pl. 5, fig. 15.

Occurrence: Sample 2-1, 130-132 cm.

Age: Upper Cretaceous.

Corbisema parallela n. sp. Hajós

(Plate 15, Figures 4, 6, 7)

Derivation of name: parallelus (lat.) $=$ with equal intervals.

Diagnosis and description: A corbisema with basal ring bent so that it appears almost 6-cornered. Peripheral stretch of each arc more or less straight and without basal spine. Triangular apical area slightly rounded.

Holotype: Prep. 2812/2 HGS, Plate 15, Figure 4.

Type locality: DSDP Leg 29, Sample $275-2-3,40-42 \mathrm{~cm}$.

Type level: Upper Cretaceous.

Dimensions: $90 \mu-120 \mu$.

Discussion: This new species differs from Dictyocha triacantha Ehr. var. archangelskiana Schulz, 1928, p. 250 , fig. 28a-c, by having a central area.

Genus DICTYOCHA Ehrenberg, 1837

Dictyocha quadralta Hanna, 1928

(Plate 16, Figure 3)

Hanna, 1928, p. 261, pl. 41, fig. 3; Loeblich et al., 1968, p. 109, pl. 19 , fig. 11.

Basal ring spines are longer than in original description.

Dimensions: overall, $130 \mu$; length of spines, $25 \mu$.

Occurrence: Sample 2-5, 116-118 cm.

Age: Upper Cretaceous.

Genus LYRAMULA Hanna, 1928

Lyramula furcula Hanna, 1928

(Plate 16, Figures 7, 8; Plate 40, Figure 2)

Hanna, 1928, p. 262, pl. 40, fig. 4, 5; Loeblich et al., 1968, p. 125, pl. 26, fig. 1, 2 .

Tips of horseshoe-shaped basal arc can be of different lengths. Sur-

face ornamentation only rarely discernible.

Dimensions: length, $40 \mu-130 \mu$; width, $20 \mu-80 \mu$.

Occurrence: Samples 1-2, 40-42 cm; 2-5, 116-118 cm.

Age: Upper Cretaceous.

\section{Lyramula furcula Hanna var. minor Deflandre, 1940}

(Plate 16, Figures 4-6; Plate 40, Figure 1)

Deflandre, 1940; in Loeblich et al., 1968, p. 125, pl. 26, fig. 3-6.

Smaller than the species, with the tips of the basal arc bent apart.

Dimensions: length, $25 \mu-40 \mu$; width, $30 \mu-35 \mu$.

Occurrences: Sample 1-1, $118-120 \mathrm{~cm}$, and together with the species.

Age: Upper Cretaceous.

Remarks: Those forms with an additional third spine, listed in the tables as Lyramula deflandrei are teratological forms of Lyramula furcula Hanna var. minor Deflandre.

\section{Lyramula simplex Hanna, 1928}

(Plate 17, Figure 1)

Hanna, 1928, p. 262, pl. 41, fig. 6; Loeblich et al., 1968, p. 126, pl. 26, fig. 9.

Basal arcs without a horn in the middle of the arc.

Dimensions: length, $85 \mu$; width, $65 \mu$.

Occurrence: Sample 2-5, 116-118 cm.

Age: Upper Cretaceous.

\section{Genus VALLACERTA Hanna, 1928 \\ Vallacerta hortonii Hanna, 1928 \\ (Plate 17, Figures 2, 3)}

Hanna, 1928, p. 262, pl. 41, fig. 7-11; Loeblich et al., 1968, p. 142, pl. 34, fig. 21-25.

Dimensions: diameter, $40 \mu-55 \mu$; length of spines, $10 \mu$.

Occurrence: Samples 2-1, 130-132 cm; 2-3, 40-42 cm.

Age: Upper Cretaceous. 
Vallacerta quadrata n. sp. Hajós

(Plate 16, Figure 9, Holotype)

Diagnosis and description: a 4-rayed Vallacerta with short spines and circular central cupula similar to Vallacerta tumidula Gleser.

Dimensions: diameter, $50 \mu$; spines $5 \mu-8 \mu$.

Holotype: Prep. 2817/1 HGS.

Type locality: DSDP Leg 29, Sample 275-2-5, 116-118 cm.

Type level: Upper Cretaceous.

Vallacerta tumidula Gleser, 1959

(Plate 17, Figures 4, 5)

In Gleser, 1966, p. 220, pl. 1, fig. 3-6; Loeblich et al., 1968, p. 144, pl. 34 , fig. $26,27$.

Dimensions: diameter, $70 \mu-80 \mu$; spines, $15 \mu-25 \mu$.

Occurrence: Sample 1-2, $40-42 \mathrm{~cm}$.

Age: Upper Cretaceous.

\section{ACKNOWLEDGMENTS}

The author thanks the Deep Sea Drilling Project and in particular N. T. Edgar, Chief Scientist, for having given her the opportunity of participating in Leg 29 of the D/V Glomar Challenger cruise from Christchurch to Wellington, New Zealand. The writer thanks President J. Fülöp, Central Office of Geology Budapest, Hungary; the Director, J. Konda, Hungarian Geological Survey, Budapest, Hungary; and Herbert Stradner for the electron micrographs produced at the Elmilab of the Geological Survey of Austria in Vienna with permission of Director A. Ruttner. Thanks to Katharina PerchNielsen of the Universitets Institut for Historisk Geologi og Paleontologi, Copenhagen, Denmark and to Dipl. Ing. Günther Lechner, Reichert/Austria, Optical Works Vienna, who provided the author with the scanning electron micrographs,

The author further thanks E. Dudich, Chief Scientist, Hungarian Geological Survey, for the critical review and translation of the manuscript, and making helpful suggestions, and Ildikó Mihály, the author's technician who prepared most of the microscope slides, assisted in drawing and photographic work, and mounted the plates.

Finally, the author expresses her appreciation to all others in the Hungarian Geological Survey who contributed to the accomplishment of this work.

\section{REFERENCES}

Deflandre, G., 1932a. Les silicoflagellées des terres fossiles à Diatomées: Francé Soc. Micr. Bull., v. 1, p. 10.

1932b. Note sur les Archaeomonadacées: Soc.

Botan. France Bull., v. 79 , p. 346.

1933. Second note sur les Archaeo-

monadacées: Soc. France Botan. Bull., v. 80, p.79.

1938. Troisieme note sur les Archaeo-

monadacées: Soc. Franc. Microsc. Bull., v. 7, p. 73.

, 1950. Contribution à l'étude des Silicoflagellidés actuels et fossiles: Microscopie, v. 2, p. 1.

, 1969. Nannofossiles siliceux I. Archaeomonadaceae: Fichier Micropaleontol. Gen. Ser. 19., Centre Nat. Rech. Sci., p. I.

Forti, A., 1909. Studi per una Monografia del genere Pyxilla /Diatomee/ e dei generi affini: La nouva Notarisia, v. 20, p. 19.

Gleser, S. I., 1962. K voprosu o filogeneze kremnevyh zhutikovyh vodoroslej: Paleontolog. Z., No. 1, p. 146. 1963. Klass Silicoflagellateae. In Osnovy Paleontologii, v. 50 , p. 161.

, 1966. Silicoflagellatophyceae. In Flora plantarum cryptogamarum USSR: Acad. Sci. USSR, Institutun Botanicum, v. 7, p. 1.
Greville, R. K., 1861-1866. Descriptions of new and rare diatoms: Micron. Soc. Trans., Ser. 1-20, p. 1.

Grove, E. and Sturt, G., 1887. On fossil marine diatomaceous deposit from Oamaru, Otago, New Zealand: QMC, v. 2, 3, p. 321.

Grunow, A., 1884. Diatomeen von Franz Josefs-Land: Acad. Wissenschaft., v. 48, p. 53.

Hanna, G. D., 1927. Cretaceous diatoms from California. Calif. Acad. Sci., Occ. Papers, v. 8, p. 1.

1928. Silicoflagellata from the Cretaceous of California: J. Paleontol., v. 1, no. 4, p. 259.

1934. Additional notes on diatoms from the Cretaceous of California: J. Paleontol., v. 8, no. 3, p. 352.

Hanna, G. D. and Brigger, A. L., 1964. Some fossil diatoms from Barbados: Calif. Acad. Sci. Occ. Papers, No. 45, p. 1.

Hustedt, F., 1927-1966. Die Kieselalgen Deutschlands, Osterreich und der Schweiz. In Rabenhorst, L.: Kryptogamen Flora, 7, v. 1, p. 1, v. 2, p. 1, v. 3, p. 1.

Jousé, A. P., 1949. Diatomovye mezozoiskih otlozhenij. In Proshkina-Lavrenko, A. I., Diatomovyj Analiz: v. 1, p. 109.

1951a. Diatomae aetatis Palaeocaeni Uralii septentrionalis: Botanicheskie Materiali otdela sporovyh rastenij, v. 7 , p. 24 .

1951b. Diatomae et Silicoflagellatae aetatis Cretae superne e montibus Uralensibus septentrionali-bus: Botanicheskie Materiali otdela sporovych rastenij, v. 7, p. 42.

1955. Species novae generis Gladius Schulz in stratura aetatis Cretaceae superioris: Botanicheskie Materiali otdela sporovyh rastenij, v. 10, p. 72 .

1963. Tip Bacillariophyta. Diatomovye vodorosli. Osnovy Paleontologii, v. 50 , p. 55.

Loeblich, A. R., III, Loeblich, L. A., Tappan, H., and Loeblich, A. R., Jr., 1968. Annotated index of fossil and recent silicoflagellates and ebridians with descriptions and illustrations of validly proposed taxa: Geol. Soc. Am., Mem. 106, p. 1.

Long, J. A., Fuge, D. P., and Smith, J., 1946. Diatoms of the Moreno Shale: J. Paleontol., v. 20, no. 2, p. 89.

Mandra, Y. T., 1968. Silicoflagellates from the Cretaceous, Eocene, and Miocene of California, U.S.A.: Calif. Acad. Sci. Proc., v. 36, p. 231.

Pantocsek, J., 1886-1905. Beiträge zur Kenntnis der fossilen Bacillarien Ungarns: v. 1, p. 1, v. 2, p. 1, v. 3, p. 1 .

Proschkina-Lavrenko, A. I., 1949. Diatomovyj Analiz. Centrales Mediales: Bot. Inst. Akad. Nauk. SSSR., v. 2, p. 1.

Rampi, L., 1940. Archaeomonadacae del Cretaceo Americano: Atti. Soc. Italian Sc. Nat., v. 79, fasc. 1, p. 60.

Schmidt, A., 1874-1959. Atlas der Diatomaceen-Kunde: v. 1120, 480 pls., Continued by Schmidt, M., Fricke, F., Heiden, H., Muller, O., Hustedt, F.

Schulz, P., 1928. Beiträge zur Kenntnis fossilen und rezenten Silicoflagellaten: Bot. Arch., v. 21, p. 225.

1935. Diatomeen aus senonen Schwammgesteinen der Danziger Bucht: Bot. Arch., v. 37, p. 1.

Sheshukova-Poretzkaja, V. S., and Gleser, Z. I., 1964. Diatomeae marinae novae e Paleogeno Ucrainiae: Novitates systematicae plantarum non vascularium, p. 78 .

Strelnikova, N. I., 1965a. De Diatomeis Cretae superioris raris et novis declivis orientalis montium Uralensium polarium: Novitates systematicae plantarum non vascularium, p. 29. 1965b. Diatomovye vodorosli iz verhnemelovyh otlozhenij severo-zapada zapadno-Sibirskoj nizmennosti: Botanicheskij Zhurnal, v. 50, p. 986.

1971. Species novae Bacillariophytorum e sedimentis Cretae posterioris in declivitate orientali partis polaris ac praepolaris montium Uralensium: Novitates systematicae plantarum non vascularium, v. 8 , p. 41 .

Van Heurck, H., 1880-1885. Synopsis des diatomées de Belgique. Anvers. 235 p. 


\section{ULTRASTRUCTURE OF UPPER CRETACEOUS SILICEOUS MICROFOSSILS FROM THE CAMPBELL PLATEAU, SITE 275}

\author{
Herbert Stradner, Geological Survey \\ of Austria, Vienna, Austria
}

The transmission electron micrographs of Late Cretaceous Diatomaceae, Archaeomonadaceae, and Silicoflagellatae (Plates 18-40) are a contribution from the Electronmicroscopical Laboratory of the Geological Survey of Austria, Vienna, to Volume 29 of the Initial Reports of the Deep Sea Drilling Project. After having been confronted with the fact that the Cretaceous microfossils from the southern Pacific still are as wellpreserved there as those from very young sediments, it became almost compulsory to study such extraordinarily well-preserved, and also extremely rarely encountered siliceous microfossils in the electron microscope.

Dr. Marta Hajos, who kindly sent cleaned core material, also did the taxonomic interpretation. More than 500 transmission electron micrographs were made on a Philips EM 75 by the author. Dipl. Ing. G. Lechner from Reichert, Austria, Optical Works, contributed a dozen scanning electronmicrographs which were taken on the new Cwikscan 100-5 instrument. These electron micrographs are thankfully acknowledged.

Thanks are due to HR Dr. Anton Ruttner, Director of the Geological Survey of Austria, for furthering this project on diatom ultrastructure.

Only a small choice of 141 pictures (Figures 3-21; Plates 18-40) are reproduced here to give an impression of the wealth of information accessible by electron- microscopic methods. Mostly small to middle-sized diatoms and other siliceous microfossils were contained in the studied fraction, but also some fragments of larger diatoms, such as Coscinodiscus morenoensis and Rattrayella antiqua. Three different modes of electronmicroscopic techniques were applied:

1) Direct electron transmission of the original fossil after platinum shadowing. The plates are shown as direct prints (fossil dark on bright background) or reversed prints (fossil bright on dark background).

2) Electron transmission of carbon replicas after platinum shadowing and subsequent chemical removal of the original fossil. The majority of photographs were done in this way. They are either shown as direct prints (fossil darker than background), but some are also shown as reversed prints (fossil bright with black shadow on dark background). Extended exposure times gave access to faintly visible details within the areolae of the diatoms (see Plate 25, Figures 2, 3).

3) Scanning electron micrographs of the original fossil after all around shadowing with copper. Direct prints on Polaroid paper.

Stereoscopic electron micrographs (stereo-couples) were also made by tilting the object-grids $\pm 5^{\circ}$; however, they are not included in this report since their reproduction requires special photographic techniques.

In spite of the fact that only a small fraction of the numerous species occurring in the studied sample was "captured" on the photographic plates, the additional information gained and the high resolution of details accomplished justifies the effort. Some of the new results are incorporated in our Systematic Descriptions of this chapter, others in our explanations to the Plates. The magnifications are given within a margin of error of $\pm 5 \%$. The scale bars are $1 \mu$ on all figures of Plates $18-40$. 



\section{PLATE 1}

(Figures 1-11, 13-18, $\times 1000$; Figure 12, $\times 5000$ )

Figures 1, 2 Melosira patera Long, Fuge, and Smith. Sample 2$1,130-132 \mathrm{~cm}$.

Figures 3, 4 Pseudopodosira westii (Smith) Gleser. Sample 2-1, $130-132 \mathrm{~cm}$.

Figures 5, 6 Skeletonema punctatum Schmidt. Sample 2-1, 130$132 \mathrm{~cm}$.

Figures 7, 8 Horodiscus rugosus n. sp. Hajós. Sample 2-5, 116$118 \mathrm{~cm}$; Holotype.

Figures 9-11 Melosira vetustissima n. sp. Hajós and Stradner. Sample 2-3, 40-42 cm; Holotype.

Figure 12 Melosira vetustissima n. sp. Hajós and Stradner. Sample 2-1, 130-132 cm; interior side of the valve; Stereoscan micrograph.

Figures 13-15 Stephanopyxis turris (Greville and Arnott) Ralfs var. intermedia Grunow. Sample 1-2, 40-42 cm.

Figures 16-18 Pyxidicula minuta Grunow. Sample 2-1, 130-132 $\mathrm{cm}$. 


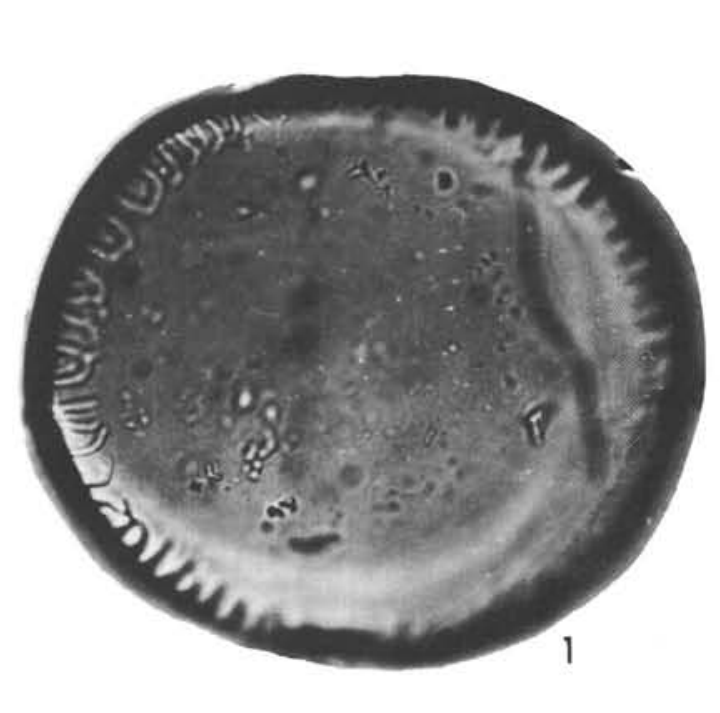

PLATE 1



\section{PLATE 2}

(All figures $\times 1000$ )

Figure $1 \quad$ Skeletonema subantarctica n. sp. Hajós. Sample 12, 40-42 cm; Holotype.

Figures 2-4 Stephanopyxis lavrenkoi Jousé. Sample 2-1, 130$132 \mathrm{~cm}$.

Figures 5, 6 Stephanopyxis discrepans Hanna. Sample 2-5, 40$42 \mathrm{~cm}$.

Figures 7, 8 Stephanopyxis simonseni $\mathrm{n}$. sp. Hajós. Sample 1-2, 40-42 cm; Holotype.

Figures 9, 10 Stephanopyxis hannai $\mathrm{n}$. sp. Hajós. Sample 1-2, 40$42 \mathrm{~cm}$; Holotype.

Figures 11, 12 Stephanopyxis superba (Greville) Grunow. Sample $2-1,130-132 \mathrm{~cm}$.

\section{PLATE 3}

(Figures 1, 2, 4-6, ×1000; Figure 3, $\times 14,000$; Figure $7, \times 2400$ )

Figures 1-3 Coscinodiscus lineatus Ehrenberg f. fossilis Jousé. Sample 2-1, 130-132 cm.

3. Transmission electronmicrograph.

Figures 4, 5 Coscinodiscus ildicoi n. sp. Hajós. Sample 2-5, 40$42 \mathrm{~cm}$; Holotype.

Figures 6, 7 Coscinodiscus morenoensis Hanna. Sample 2-1, $130-132 \mathrm{~cm}$.

7. Transmission electronmicrograph.

(See p. 946) 
PLATE 2
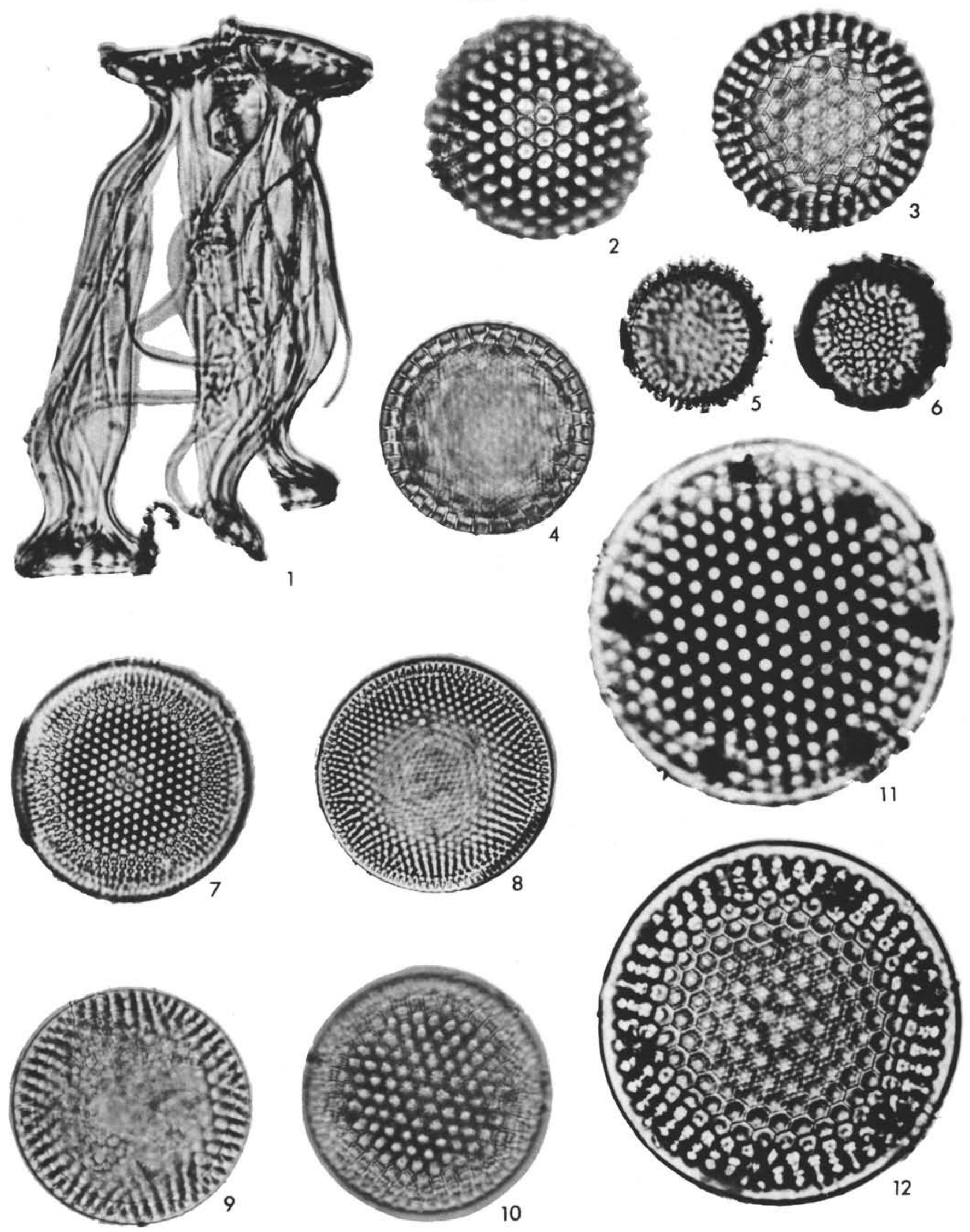
PLATE 3



\section{PLATE 4}

(Figures 1-16, $\times 1000$; Figure 17, $\times 2875$ )

Figure 1 Coscinodiscus circumspectus Long, Fuge, and Smith. Sample 1-2, 40-42 cm.

Figure 2 Coscinodiscus morenoensis Hanna. Sample 2-1, $130-132 \mathrm{~cm}$.

Figures 3, 4 Ethmodiscus sp. Hajós. Sample 2-1, 130-132 cm.

Figures 5,6 Poretzkia circularis Jousé.

5. Sample 1-1, $118-120 \mathrm{~cm}$.

6. Sample 1-3, 40-42 cm.

Figures 7, 8 Cladogramma simplex n. sp. Hajós. Sample 2-1, 130-132 cm; Holotype.

Figures 9-11 Cladogramma jordanii Hanna.

9, 11. Sample 1-1, 118-120 cm.

10. Sample $2-4,40-42 \mathrm{~cm}$.

Figure 12 Xanthiopyxis sp. 2. Hajós. Sample 2-1, 130-132 $\mathrm{cm}$.

Figure 13 Xanthiopyxis sp. 1. Hajós. Sample 2-5, 116-118 $\mathrm{cm}$.

Figures 14, 15 Rattrayella antiqua n. sp. Hajós and Stradner. Sample 2-3, 40-42 cm; Holotype.

Figures 16, 17 Xanthiopyxis granti Hanna. Sample 2-1, 130-132 $\mathrm{cm}$.

17. Transmission electron micrograph.

(See p. 948) 
PLATE 4



\section{PLATE 5}

(Figures 1-18, 20-23, $\times 1000$; Figure 19, $\times 2520$;

Figure $24, \times 3800$ )

Figures 1-3 Chasea bicornis Hanna

1, 2. Sample 2-1, 130-132 cm.

3. Sample $2-5,40-42 \mathrm{~cm}$.

Figures 4, 5 Chasea ornata n. sp. Hajós and Stradner. Sample 2-5, 40-42 cm; Holotype.

Figures 6,7 Biddulphia cretacea n. sp. Hajós and Stradner. Sample 2-3, 40-42 cm; Holotype.

Figures 8, 9 Biddulphia sparsepunctata n. sp. Hajós. Sample 23, 40-42 cm; Holotype.

Figures 10, 11 Hemiaulus danicus Grunow. Sample 2-5, 116-118 $\mathrm{cm}$.

Figure 12 Pseudostictodiscus sp. Hajós. Sample 2-3, 40-42 $\mathrm{cm}$.

Figures 13, 14 Huttonia antiqua n. sp. Hajós and Stradner. Sample 1-3, 40-42 cm; Holotype.

Figures 15, 16 Huttonia punctata $\mathrm{n}$. sp. Hajós. Sample 1-3, 40-42 $\mathrm{cm}$; Holotype.

Figures 17-19 Hemiaulus altus n. sp. Hajós. Holotype.

17, 18. Sample $1-2,40-42 \mathrm{~cm}$.

19. Sample $2-5,40-42 \mathrm{~cm}$; stereoscan micrograph.

Figure 20 Hemiaulus gleseri n. sp. Hajós. Sample 2-5, 40-42 $\mathrm{cm}$.

Figures 21, 22 Hemiaulus echinulatus Jousé. Sample 1-2, 40-42 $\mathrm{cm}$.

Figures 23, 24 Actinoptychus packi Hanna

23. Sample 1-1, 118-120 cm.

24. Sample 2-1, 130-132 cm; transmission electron micrograph.

(See p. 950) 
Plate 5



\section{PLATE 6}

(Figures 1-6, 8-13 ×1000; Figures 7, $14 \times 2100$ )

Figures 1-3 Hemiaulus polycystinorum Ehrenberg var. brevicornis Jousé.

1, 2. Sample 2-1, 130-132 cm.

3. Sample $2-5,116-118 \mathrm{~cm}$.

Figures 4-7 Hemiaulus polycystinorum Ehrenberg.

4. Sample 2-1, 130-132 cm.

5 , 6. Sample 2-4, $40-42 \mathrm{~cm}$.

7. Sample $2-5,40-42 \mathrm{~cm}$; stereoscan micrograph.

Figure 8 Hemiaulus curvatulus Strelnikova. Sample 2-5, 40$42 \mathrm{~cm}$.

Figure 9 Hemiaulus polymorphus Grunow. Sample 2-1, 130$132 \mathrm{~cm}$.

Figures 10, 11 Hemiaulus kondai n. sp. Hajós.

10. Sample 2-1, 130-132 cm.

11. Sample 1-2, 40-42 cm; Holotype.

Figures 12-14 Hemiaulus prae-elegans Jousé.

12. Sample 2-5, 116-118 cm.

13 , 14. Sample $2-5,40-42 \mathrm{~cm}$; stereoscan micrograph.

(See p. 952) 
PLATE 6
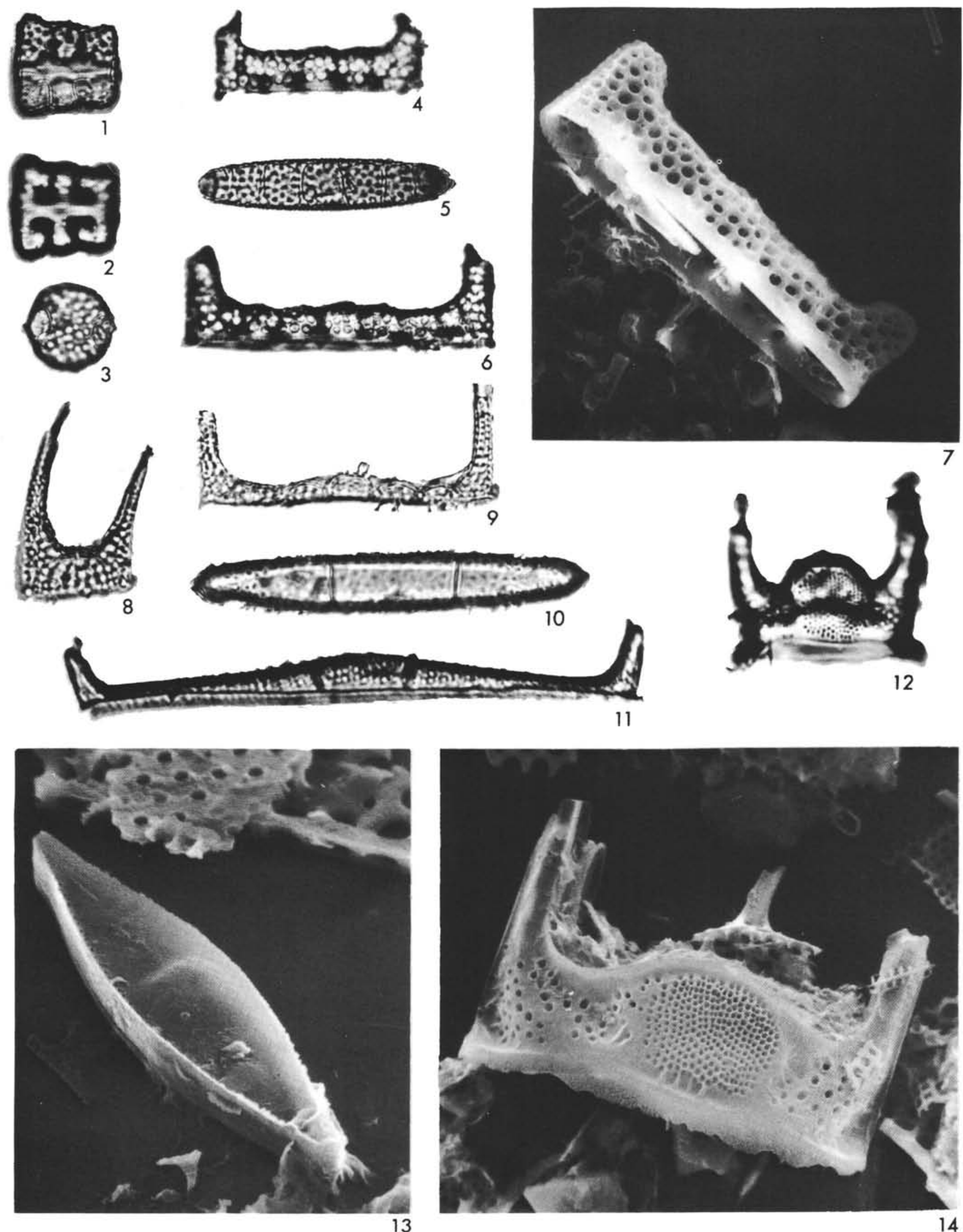


\section{PLATE 7}

(Figures 1-4, 6-13 × 1000; Figures 5, 14, $15 \times 2575$ )

Figure 1 Rhisosolenia cretacea n. sp. Hajós and Stradner. Sample 1-1, 118-120 cm; Holotype.

Figures 2-5 Hemiaulus schmidti n. sp. Hajós.

2, 3. Sample 2-1, 130-132 cm; Holotype.

4. Sample 2-5, 130-132 cm.

5. Sample 2-5, 40-42 cm; stereoscan micrograph.

Figures 6, 7 Hemiaulus gleseri n. sp.

6. Sample 1-1, 118-120 cm; Holotype.

7. Sample $2-5,116-118 \mathrm{~cm}$.

Figure $8 \quad$ Hemiaulus andrewsi n. sp. Hajós. Sample 2-5, 116$118 \mathrm{~cm}$; Holotype.

Figures 9, 10 Triceratium kuepperi n. sp. Hajós and Stradner. Sample 1-2, 40-42 cm; Holotype.

Figures 11-15 Triceratium kennetti n. sp. Hajós and Stradner. 11-13. Sample 2-5, 116-118 cm; Holotype. 14. Sample $2-5,40-42 \mathrm{~cm}$; stereoscan micrograph; view of the interior side of the valve. 15. Sample 2-5, 40-42 cm; stereoscan micrograph; girdle view.

(See p. 954) 
PLATE 7
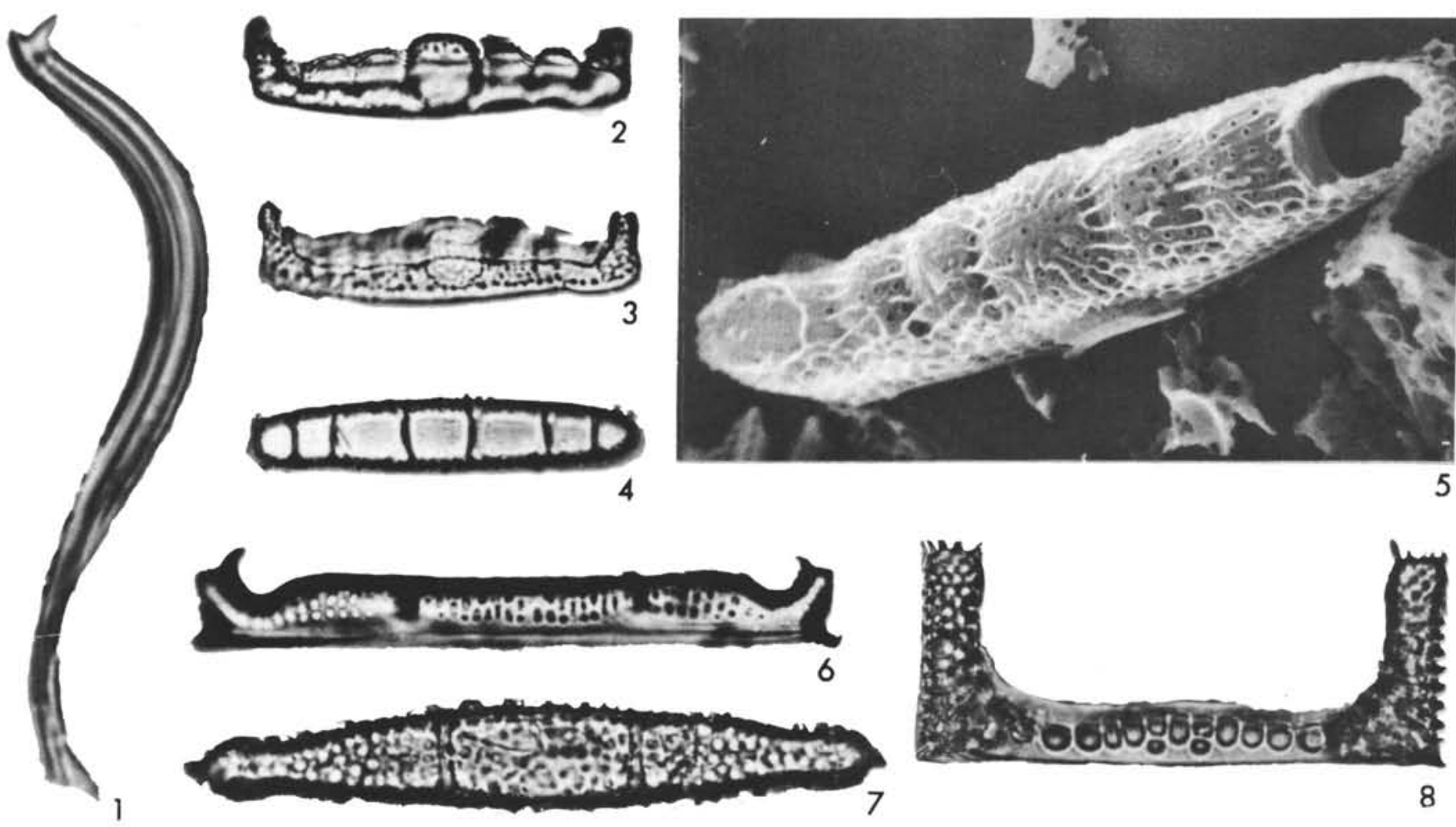



9

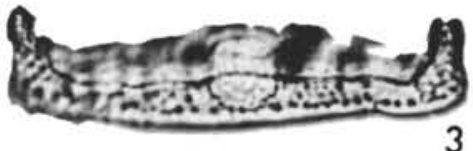

प1口冋0

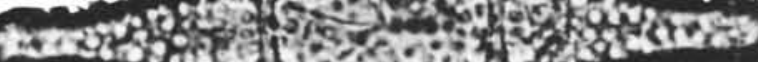

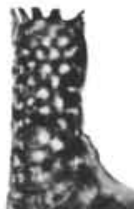

$2,2.0600050000$ it

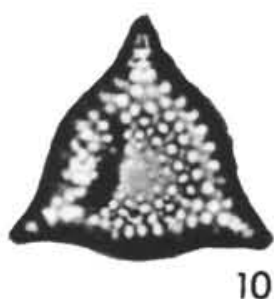

10



11
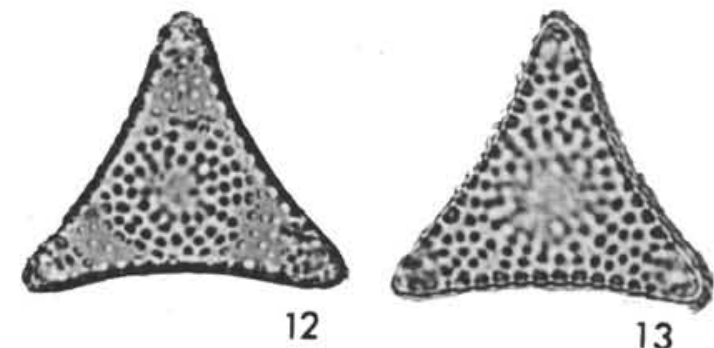

13
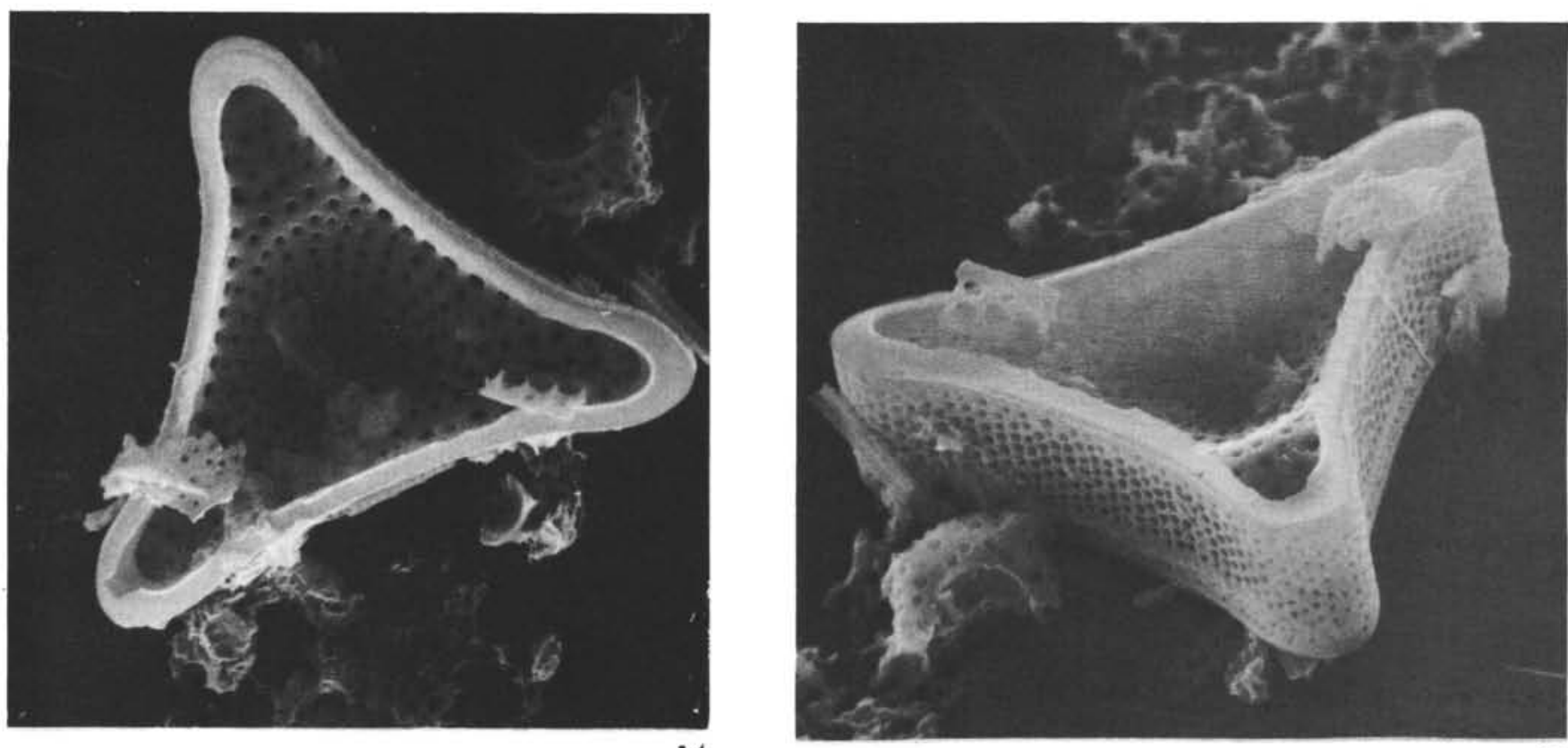


\section{PLATE 8}

(All figures $\times 1000$ )

Figures 1, 2 Triceratium schulzii Jousé. Sample 2-5, 40-42 cm.

Figures 3, 4 Triceratium sectum Witt. Sample 2-5, 116-118 cm.

Figures 5, 6 Triceratium praetenue Greville. Sample 1-1, 118$120 \mathrm{~cm}$.

Figures 7, 8 Triceratium dignum Long, Fuge, and Smith. Sample $1-1,118-120 \mathrm{~cm}$.

Figures 9, 10 Triceratium arietinum Schmidt. Sample 2-1, 130$132 \mathrm{~cm}$.

Figures 11, 12 Triceratium cristatum Pantocsek. Sample 2-5, 40$42 \mathrm{~cm}$.

Figures 13, 14 Triceratium edgari n. sp. Hajós. Sample 1-1, 118$120 \mathrm{~cm}$; Holotype.

Figures 15, 16 Triceratium gratum Schmidt, Sample 2-5, 116-118 $\mathrm{cm}$.

(See p. 956)

\section{PLATE 9}

(Figures 1-10, $\times 1000$; Figure $11, \times 2520$ )

Figures 1, 2 Triceratium occultum Hustedt. Sample 2-1, 130$132 \mathrm{~cm}$.

Figure 3 Triceratium nobile Witt. Sample 1-1, 118-120 cm.

Figure 4 Triceratium idoneum Pantocsek. Sample 2-3, 40-42 $\mathrm{cm}$.

Figures 5, 6 Trinacria tristictia Hanna. Sample 2-3, 40-42 cm.

Figures 7, 8 Trinacria pileolus (Ehrenberg) Grunow. Sample 12, $40-42 \mathrm{~cm}$.

Figures 9-11 Trinacria aries Witt. Sample 2-5, 40-42 cm.

11. Stereoscan micrograph; view of the exterior side of the valve.

(See p. 957) 
PLATE 8

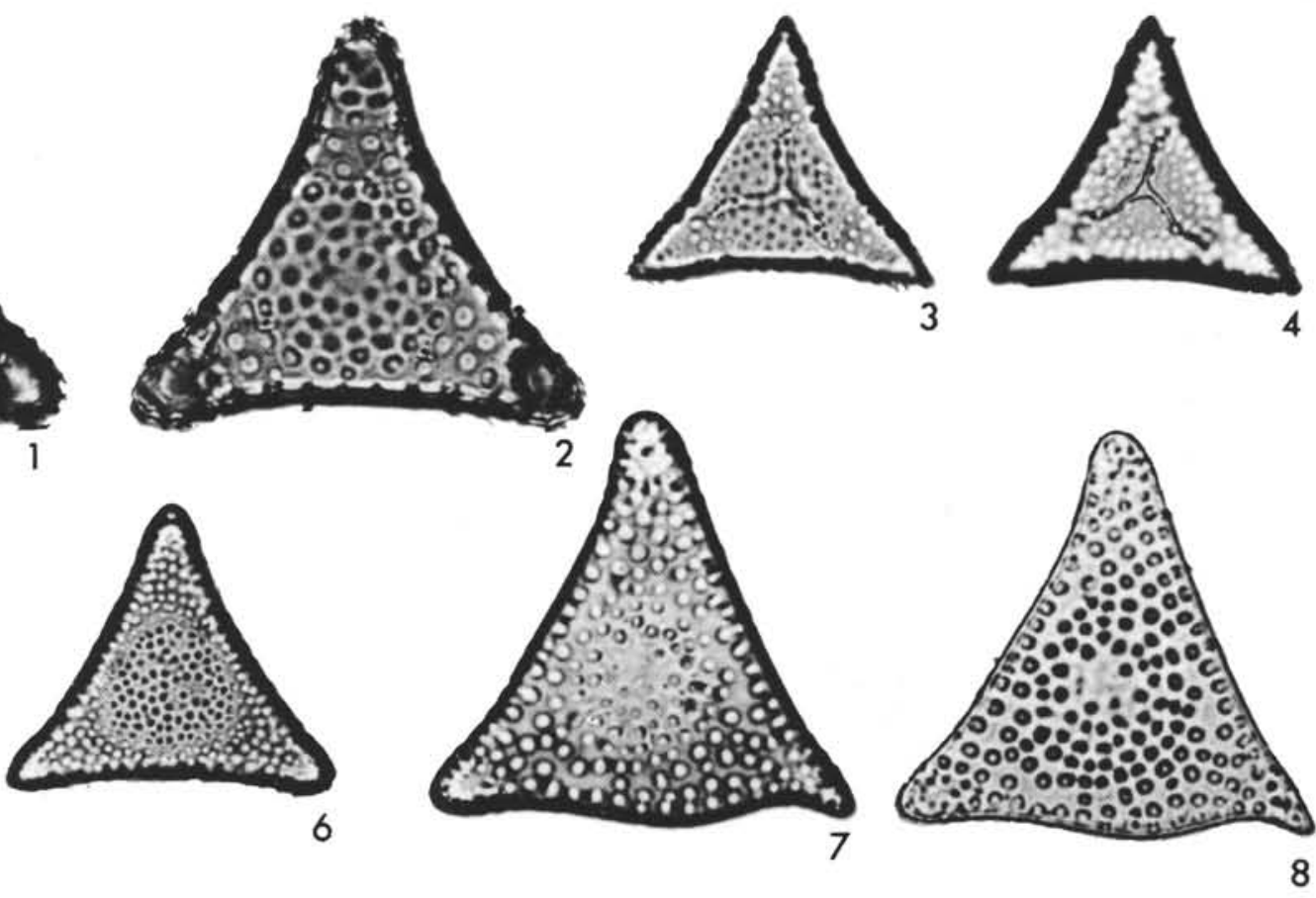

8
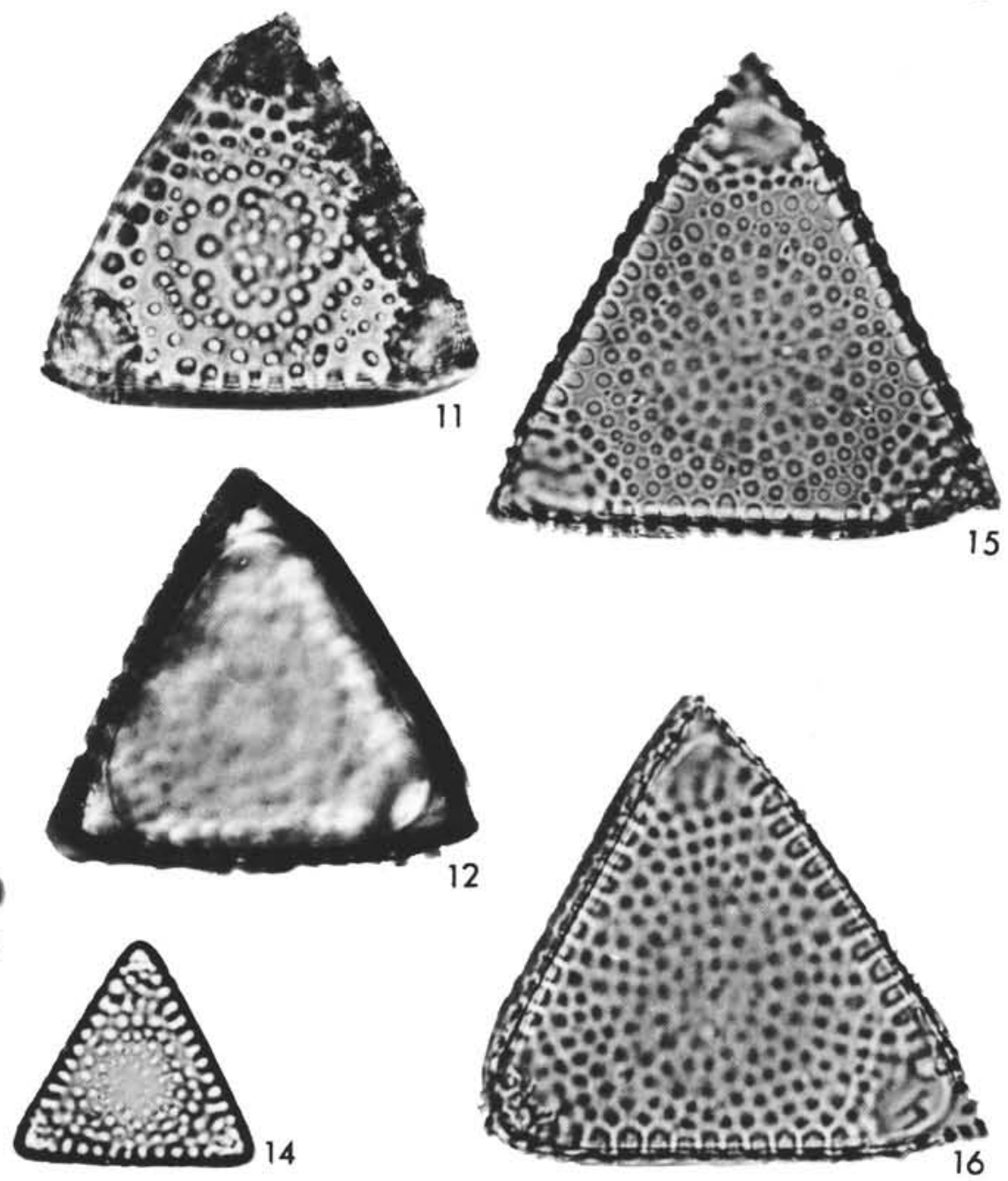
PLATE 9
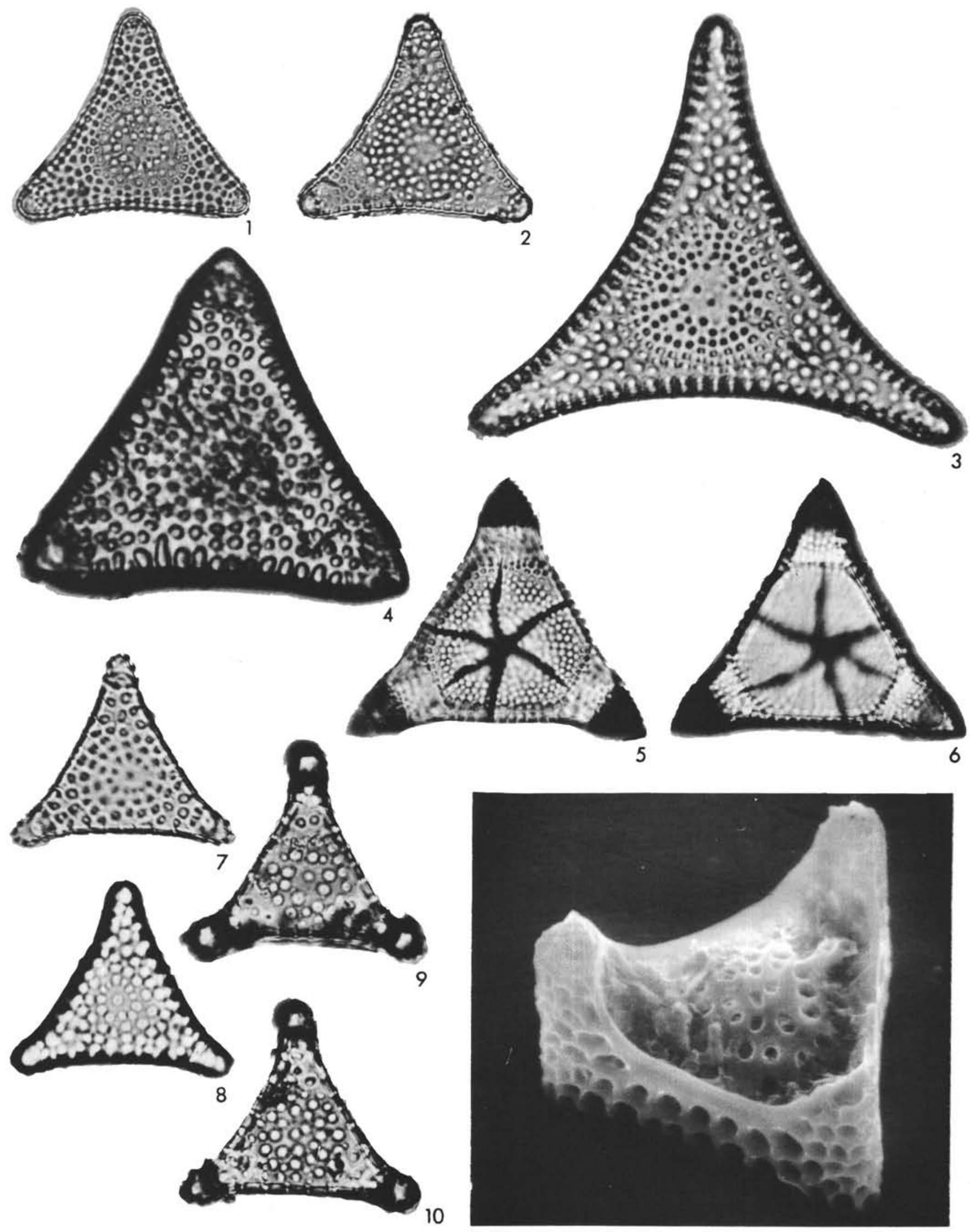
PLATE 10

(All figures $\times 1000$ )

Figure 1 Trinacria excavata Heiberg. Sample 2-3, 40-42 cm.

Figure 2 Trinacria anissimowii Jousé. Sample 2-3, 40-42 cm.

Figures 3, 4 Cerataulina cretacea n. sp. Hajós.

3. Sample 2-5, 116-118 cm; Holotype.

4. Sample 2-1, 130-132 cm.

Figures 5, 6 Trinacria insipiens Witt. Sample 2-5, 116-118 cm.

Figures 7, 8 Trinacria princeps Witt. Sample 2-1, 130-132 cm.

Figure 9 Kentrodiscus armatus n. sp. Hajós. Sample 2-1, $130-132 \mathrm{~cm}$.

Figure 10 Kentrodiscus aculeatus Hanna. Sample 2-5, 116$118 \mathrm{~cm}$; View from below.

Figures 11, 12 Goniothecium odontella Ehrenberg. Sample 2-1, 130-132 cm; Girdle view. 

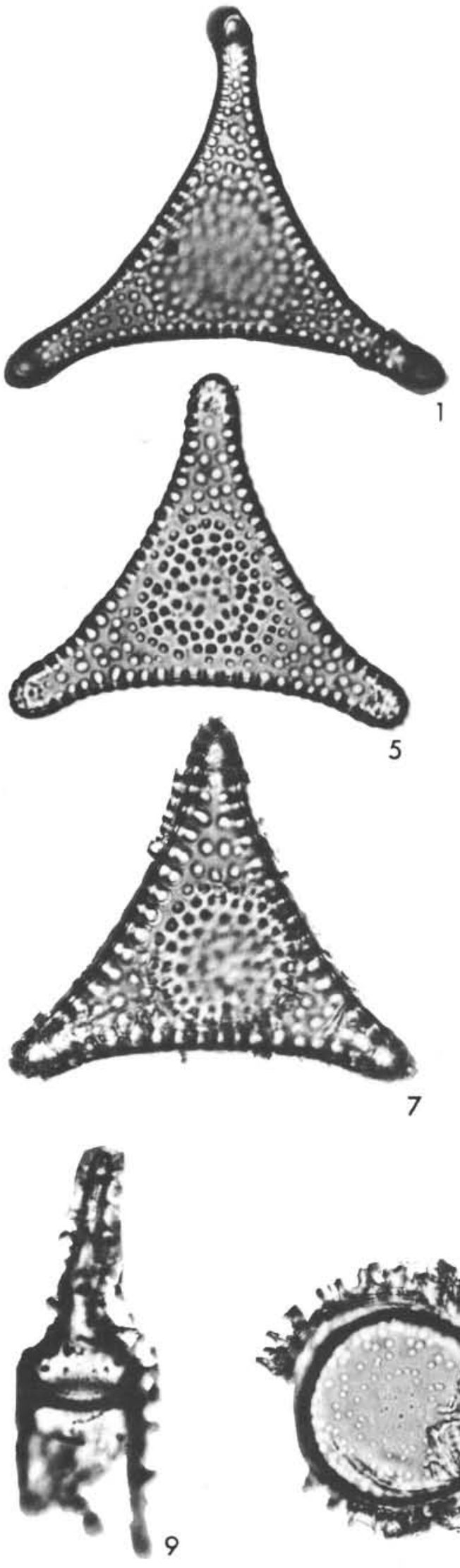

PLATE 10






\section{PLATE 11}

(Figures $1-15 \times 1000$; Figure $16 \times 3740$ )

Figures 1, 2 Gladius pacificus n. sp. Hajós and Stradner. Sample 2-3, 40-42 cm; Holotype.

Figures 3, 4 Gladius pacificus n. sp. f. minor n. f. Hajós. Sample 2-1, 130-132 cm; Holotype.

Figures 5, 6 Gladius speciosus Schulz. Sample 2-1, 130-132 cm.

Figures 7-12 Gladius jouseanus n. sp. Hajós.

7, 8. Sample 2-1, 130-132 cm.

9, 10. Sample 1-2, 40-42 cm; Holotype.

11. Sample 2-3, $40-42 \mathrm{~cm}$.

Figure 13 Gladius maximus n. sp. Hajós. Sample 2-1, 130-132 cm; Holotype.

Figures 14-16 Sceptroneis grunowii Anissimowa.

14, 15. Sample 2-1, 130-132 cm.

16. Sample $2-5,40-42 \mathrm{~cm}$; stereoscan micrograph. 
CRETACEOUS ARCHAEOMONADACEAE, DIATOMACEAE, SILICOFLAGELLATA

PLATE 11
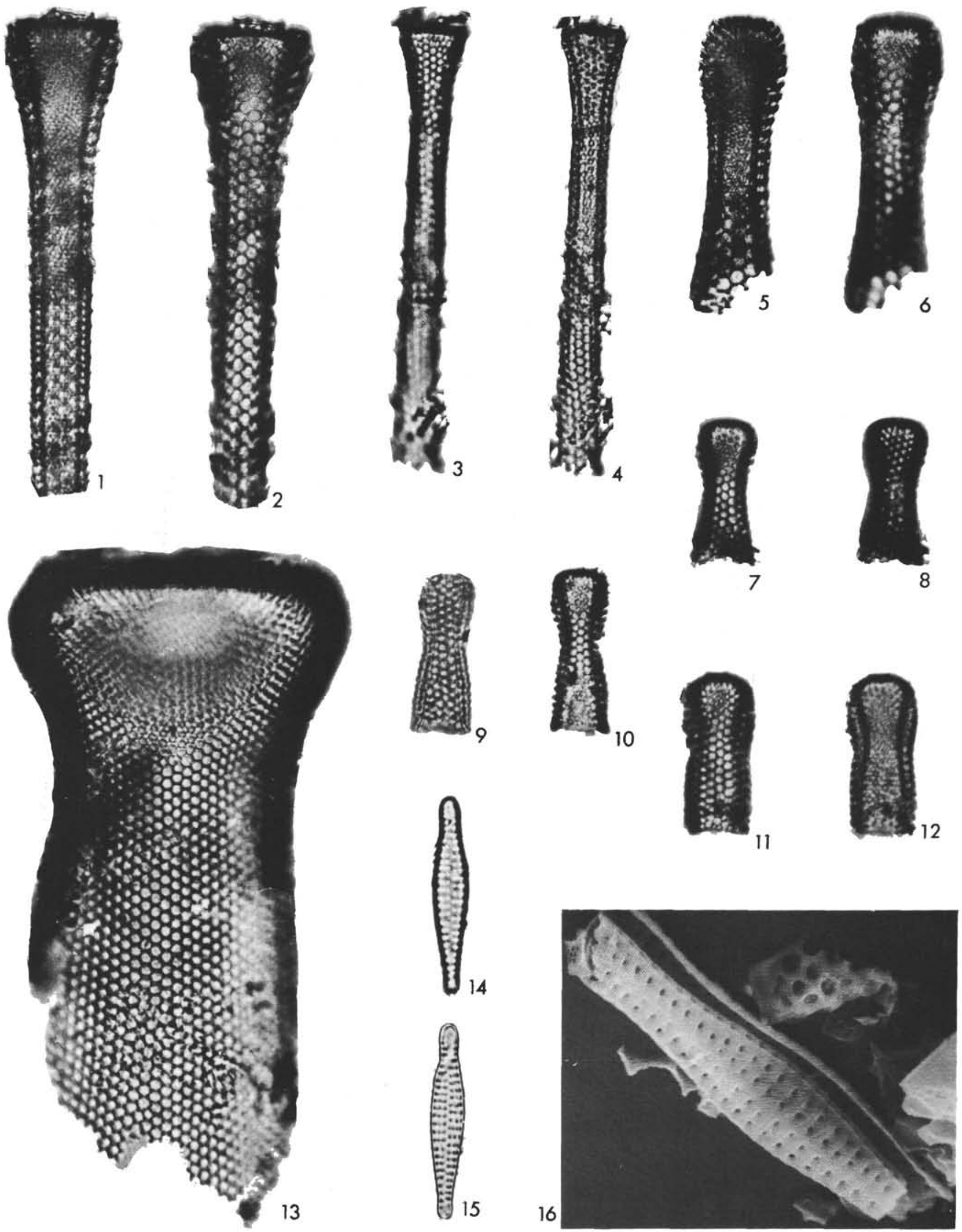
PLATE 12

(Figures 1-20 × 1000; Figures 21, $22 \times 2600$ )

Figures 1, 2 Pseudopyxilla russica (Pantocsek) Forti. Sample 2$5,116-118 \mathrm{~cm}$.

Figure 3 Pseudopyxilla americana (Ehrenberg) Forti. Sample $2-5,116-118 \mathrm{~cm}$.

Figures 4, 5 Pseudopyxilla jouseae n. sp. Hajós. Sample 1-1, 118-120 cm; Holotype.

Figure $6 \quad$ Pterotheca cf. aculeifera Grunow. Sample 2-5, 116$118 \mathrm{~cm}$.

Figure 7 Pterotheca capreolus (Forti.)n. comb. Hajós. Sample 2-1, 130-132 cm.

Figures 8, 9, Pterotheca crucifera Hanna.

22 8. Sample 1-2, $40-42 \mathrm{~cm}$.

9. Sample 2-1, 130-132 cm.

22. Sample 2-1, 130-132 cm; stereoscan micrograph.

Figures 10, 11 Pterotheca aculeata n. sp. Hajós.

10. Sample 2-1, 130-132 cm.

11. Sample 2-5, 116-118 cm; Holotype.

Figures 12-15 Pterotheca (Micrampulla) parvula Hanna n. comb. Hajós and Stradner. Sample 2-1, 130-132 cm.

Figures 16-18, Pterotheca cretacea n. sp. Hajós and Stradner. 21

16. Sample $2-1,130-132 \mathrm{~cm}$.

17, 18. Sample 1-1, 118-120 cm; Holotype.

21. Sample 2-1, 130-132 cm; stereoscan micrograph.

Figures 19, 20 Kentrodiscus armatus n. sp. Hajós. Sample 2-1, 130-132 cm; Holotype. 

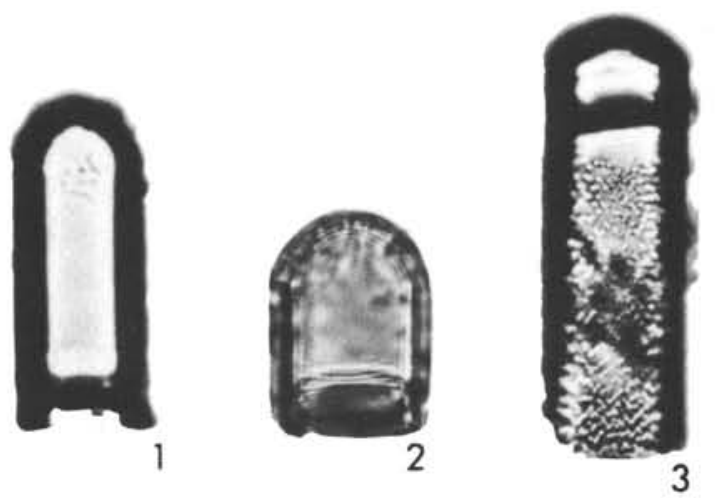

PLATE 12
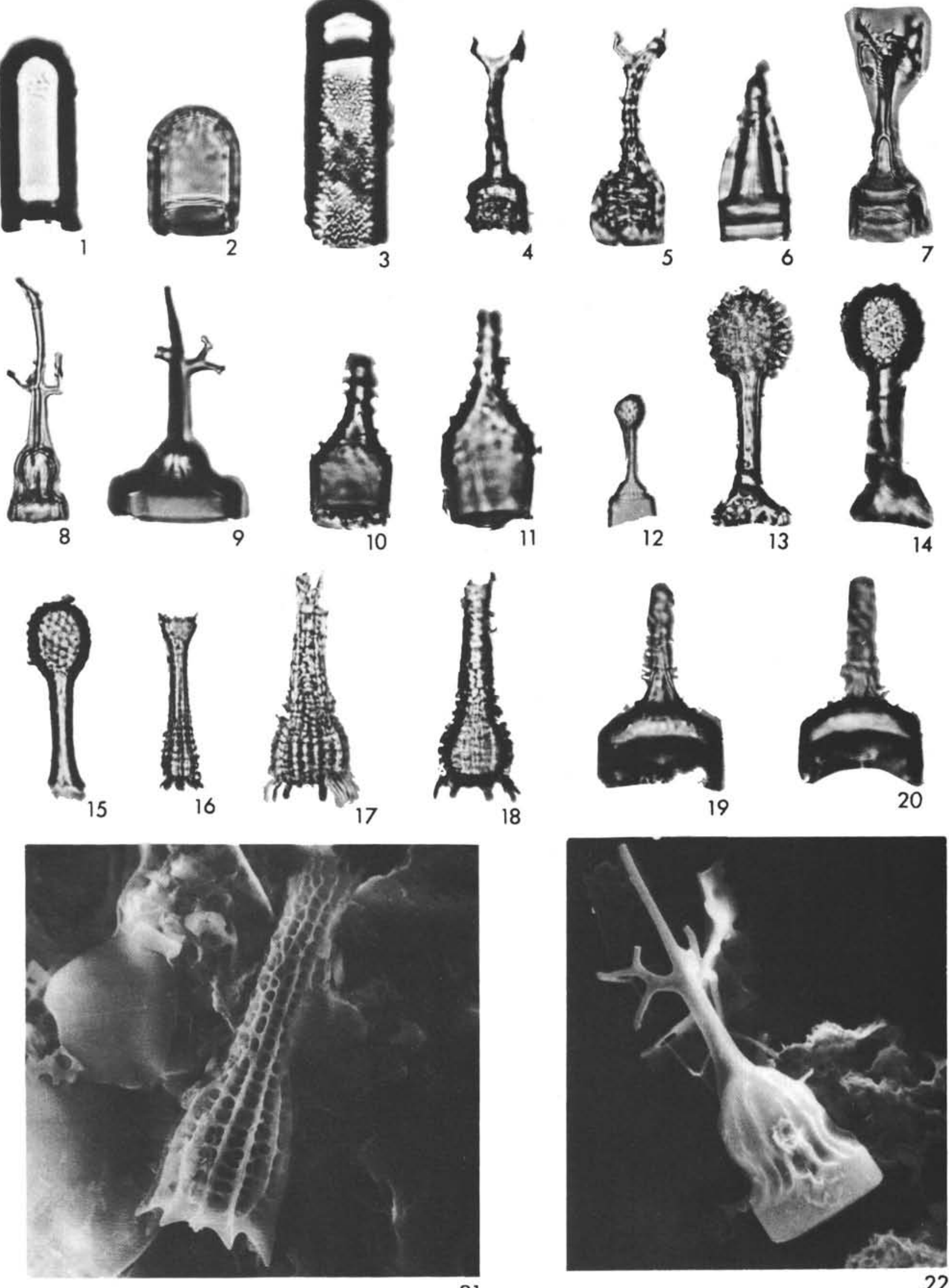


\section{PLATE 13 \\ (All figures $\times 1000$ )}

Figures 1-6 Acanthodiscus antarcticus n. sp. Hajós. 1-3. Sample 2-5, 116-118 cm; Holotype. 4-6. Sample 2-5, 116-118 cm.

Figures 7, 9, Acanthodiscus ornatus n. sp. Hajós and Stradner. 10 7. Sample 2-3, $40-42 \mathrm{~cm}$.

9, 10. Sample 2-3, 40-42 cm; Holotype.

Figure 8 Acanthodiscus convexus n. sp. Hajós and Stradner. Sample 2-1, 130-132 cm; Holotype.

Figure $11 \quad$ Pyrgodiscus sinuatus n. sp. Hajós and Stradner. Sample 2-5, 40-42 cm; Holotype.

Figure 12 Longinata acuta n. sp. Hajós. Sample 1-2, 40-42 $\mathrm{cm}$; Generotype, Holotype.

Figures 13, 14 Sceptroneis praecaducea $\mathrm{n}$. sp. Hajós and Stradner. Sample 1-1, 118-120 cm; Holotype.

Figures 15, 16 Incisoria punctata $\mathrm{n}$. sp. Hajós and Stradner. Sample 2-1, 130-132 cm; Generotype, Holotype.

Figures 17, 18 Sceptroneis sp. Sample 1-1, 118-120 cm.

Figure 19 Eunotogramma fueloepi n. sp. Hajós. Sample 2-1, 130-132 cm; Holotype.

Figures 20, 21 Incisoria inordinata n. sp. Hajós. Sample 2-3, 40-42 cm; Holotype.

Figures 22, 25 Incisoria lanceolata n. sp. Hajós and Stradner. 22. Sample 2-5, 116-118 cm; Holotype.

25. Sample 2-1, 130-132 cm.

Figure 23 Anaulus incisus n. sp. Hajós and Stradner. Sample 1-3, 40-42 cm; Holotype.

Figure 24 Helminthopsis wornardti n. sp. Hajós. Sample 2-3, 40-42 cm; Holotype.

Figure 26 Anaulus subantarcticus n. sp. Hajós. Sample 2-3, 40-42 cm; Holotype. 
PLATE 13
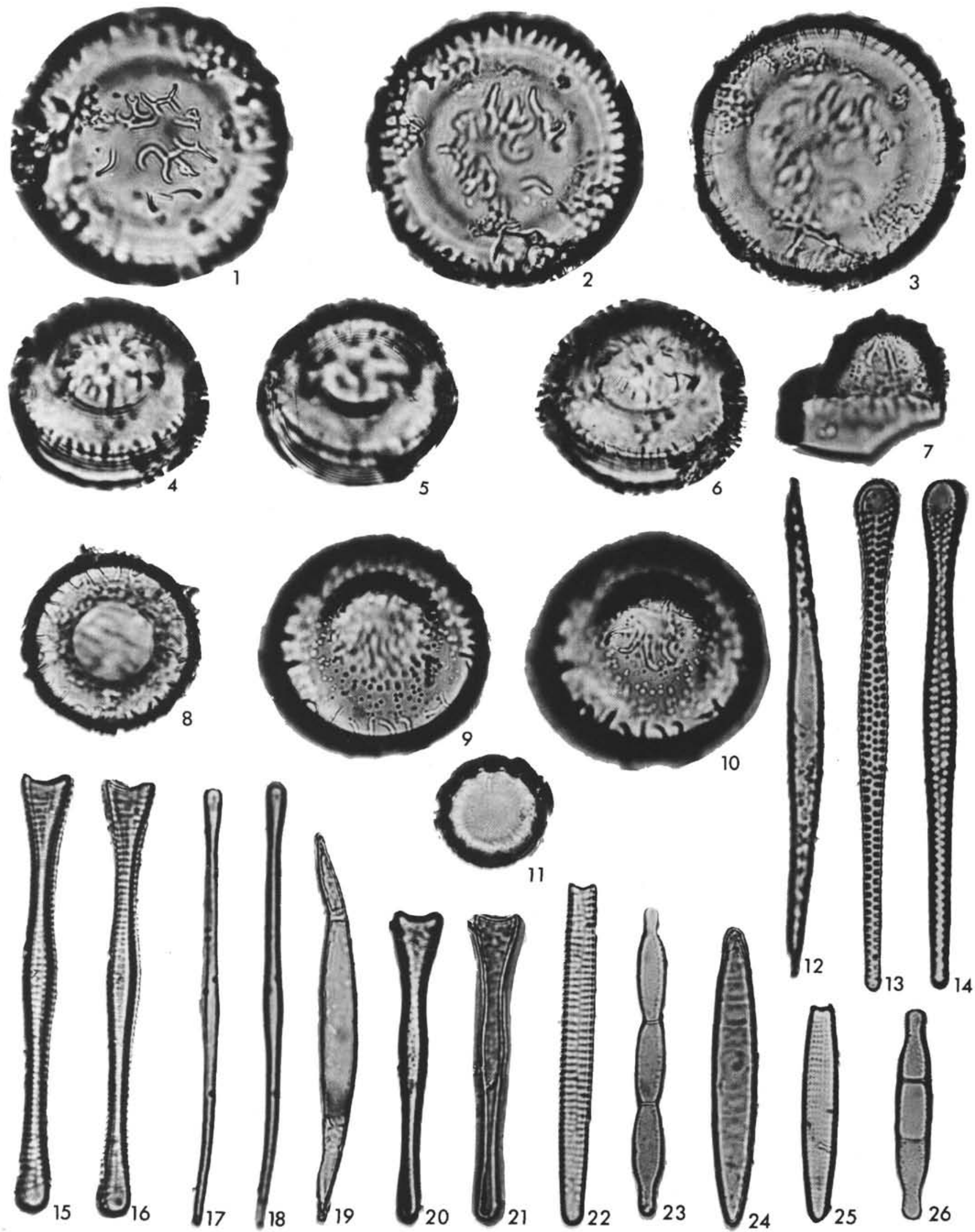
PLATE 14

(Figures 1-4, 6, 8-34 ×1000; Figures 5, $7 \times 2000$ )

Figure 1 Epithelion spinifer Pantocsek. Sample 2-4, 40-42 $\mathrm{cm}$.

Figure 2 Epithelion russicum Pantocsek. Sample 2-4, 40-42 $\mathrm{cm}$.

Figures 3, 4 Epithelion curvatum Pantocsek. Sample 1-1, 118$120 \mathrm{~cm}$.

Figures 5-11 Acanthosphaeridium reticulatum n. sp.Hajós and Stradner.

5, 7. Sample 2-3, 40-42 cm; Generotype, Holotype.

6. Sample 2-1, 130-132 cm; Electron micrograph. 8 , 9. Sample $1-1,118-120 \mathrm{~cm}$.

10 , 11. Sample $2-5,116-118 \mathrm{~cm}$.

Figures 12, 13 Archaeomonas ambigua Rampi. Sample 2-4, 40-42 $\mathrm{cm}$.

Figures 14-16 Archaeomonas chiarugii Rampi. Sample 2-4, 40-42 $\mathrm{cm}$.

Figures 17, 18 Archaeomonas cretacea Rampi. Sample 2-4, 40-42 $\mathrm{cm}$.

Figures 19, 20 Archaeomonas heteroptera Deflandre. Sample 2-4, $40-42 \mathrm{~cm}$.

Figures 21, 22 Archaeomonas membranosa Rampi. Sample 2-4, $40-42 \mathrm{~cm}$.

Figures 23, 24 Archaeomonas spinulosa Rampi. Sample 2-1, 130$132 \mathrm{~cm}$.

Figures 25-27 Litheusphaerella spectabilis Deflandre. Sample 2-5, $116-118 \mathrm{~cm}$.

Figures 28, 29 Archaeomonas smithi Rampi. Sample 2-1, 130-132 $\mathrm{cm}$.

Figures 30, 31 Pararchaeomonas colligera Deflandre. Sample 2-1, $130-132 \mathrm{~cm}$.

Figures 32-34 Pararchaeomonas ornata n. sp. Hajós. Sample 2-3, 40-42 cm; Holotype. 
PLATE 14

PLATE 15

(All figures $\times 1000$ )

Figure 1 Corbisema geometrica Hanna. Sample 2-1, 130-132 $\mathrm{cm}$.

Figures 2, 3, 5 Corbisema geometrica Hanna var. apiculata Jousé. 2, 5. Sample 2-5, 116-118 cm.

3. Sample 1-2, 40-42 cm.

Figures 4, 6, 7 Corbisema parallela n. sp. Hajós. Sample 2-3, 40$42 \mathrm{~cm}$.

4. Holotype.

\author{
PLATE 16 \\ (All figures $\times 1000$ )
}

Figures 1, 2 Lyramula deflandrei n. sp. Hajós. Sample 2-1, 130$132 \mathrm{~cm}$; Holotype.

Figure 3 Dictyocha quadralta Hanna. Sample 2-5, 116-118 $\mathrm{cm}$.

Figures 4-6 Lyramula furcula Hanna var. minor Deflandre. 4, 6. Sample 2-5, 116-118 cm.

5. Sample 1-1, $118-120 \mathrm{~cm}$.

Figures 7, 8 Lyramula furcula Hanna.

7. Sample 1-2, 40-42 cm.

8. Sample 2-1, 130-132 cm.

Figure 9 Vallacerta quadrata n. sp. Hajós. Sample 2-5, 116$118 \mathrm{~cm}$; Holotype.

(See p. 970) 


$$
\begin{aligned}
& 000 \\
& \frac{D_{8}}{80}
\end{aligned}
$$







PLATE 17

(All figures $\times 1000$ )

Figure $1 \quad$ Lyramula simplex Hanna. Sample 2-5, 116-118 cm.

Figures 2, 3 Vallacerta hortonii Hanna. Sample 2-1, 130-132 $\mathrm{cm}$.

Figures 4, $5 \quad$ Vallacerta tumidula Gleser. Sample 1-2, 40-42 cm.

Figures 6-11 Porifera spicules.

6-8, 10, 11. Sample 2-1, 130-132 cm.

9. Sample 2-5, $116-118 \mathrm{~cm}$.

(See p. 972)

PLATE 18

Transmission electron micrographs of Cretaceous diatoms from Sample 2-1, 130-132 cm

Figures 1, 2 Melosira vetustissima n. sp. Hajós and Stradner.

1. Valve view, exterior side; $\times 9000$.

2. Valve in oblique view, direct transmission; $\times 18,000$.

Figures 3, 4 Pyrgodiscus sinuatus n. sp. Hajós and Stradner. Valve view.

3. Reversed print; $\times 9000$.

4. Close up of sinus; $\times 18,000$.

Figures 5, 6 Pyrgodiscus triangulatus n. sp. Hajós and Stradner Paratype. Valve view.

5. $\times 4500$.

6. $\times 8000$.

(See p. 973) 
PLATE 17

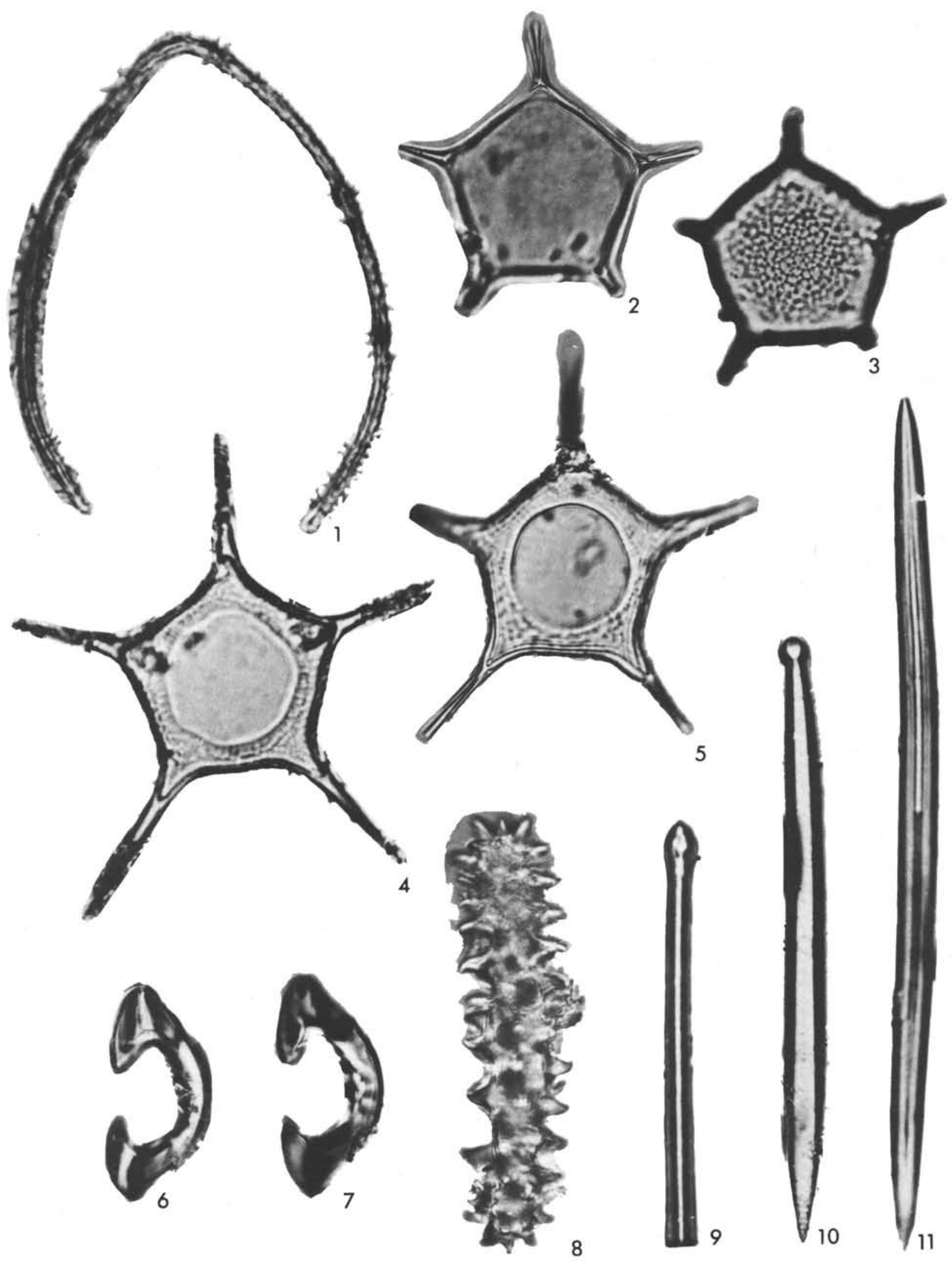




\section{PLATE 18}
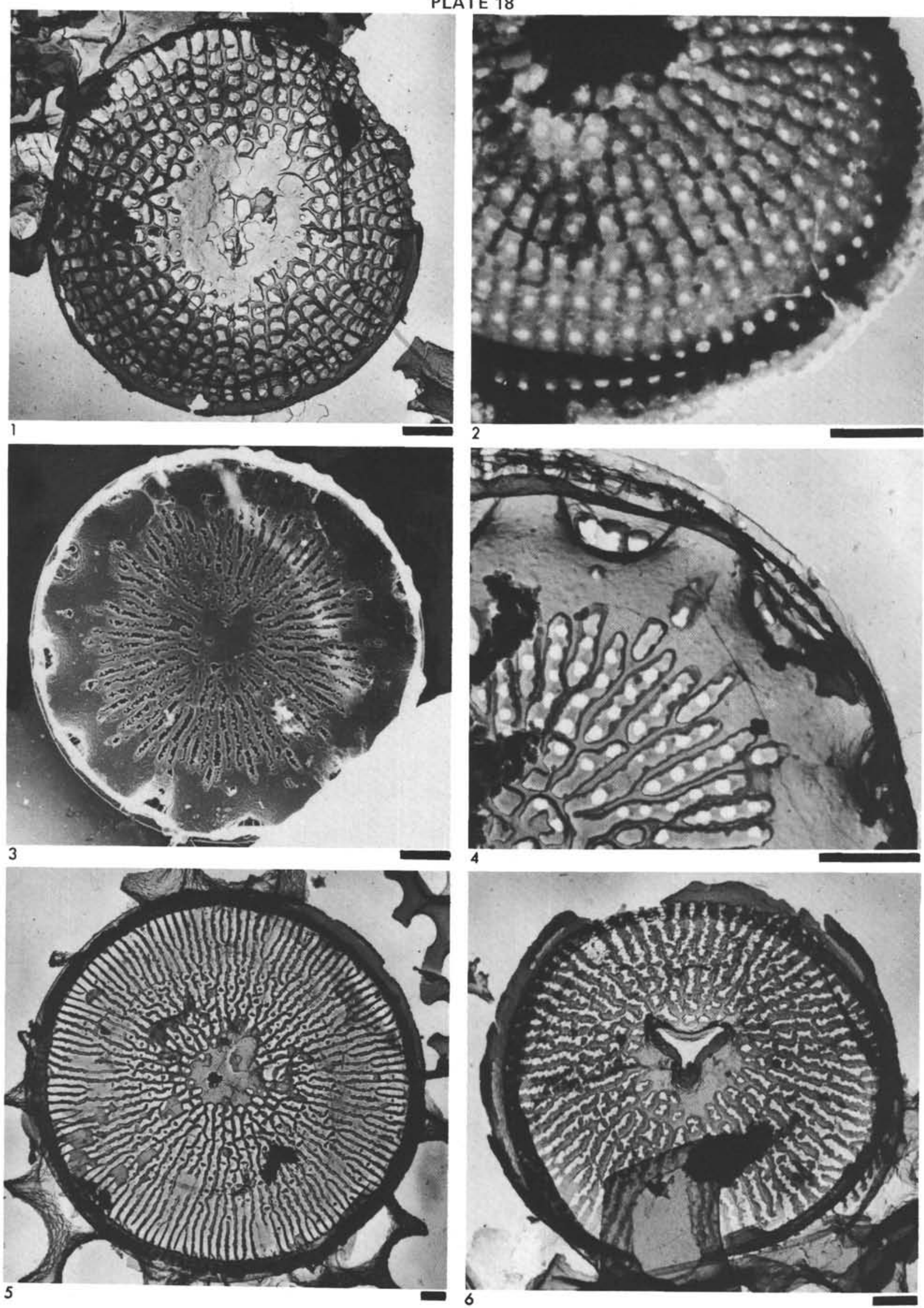
PLATE 19

Cretaceous diatoms from Sample 2-1, 130-132 cm

Figures 1, 2, 4 Pseudopodosira westii (Smith) Sheshakova and Gleser.

1. Valve view; $\times 4000$.

2. Valve view, close up showing ring of pores; $\times 7500$.

4. Central disc of the valve; $\times 3300$.

Figure $3 \quad$ Pseudopodosira sp. Hajós. Valve view; $\times 9000$.

Figure 5 Unidentified lid of a permanent diatom-spore. Valve view; $\times 14,000$.

Figure 6 Benetorus fantasmus Hanna. Valve view of external side; reversed print of carbon replica; $\times 9600$.

PLATE 20

Cretaceous diatoms from Sample 2-1, 130-132 cm

Figures 1, 2 Skeletonema punctatum Schmidt.

1. Oblique view; $\times 6000$.

2. Oblique view; close up showing connections between two valves and marginal pores; $\times 21,000$.

Figure $3 \quad$ Skeletonema sp. Valve view. $\times 4150$.

Figure 4 Skeletonema alternans n. sp. Stradner. Oblique side view; $\times 8000$; Holotype.

Figure $5 \quad$ Melosira sp. Valve view of disc with finely crenulated margin; $\times 8660$.

Figure 6 Cladogramma jordani Hanna. Valve view of internal side; $\times 4500$.

(See p. 976) 


\section{PLATE 19}
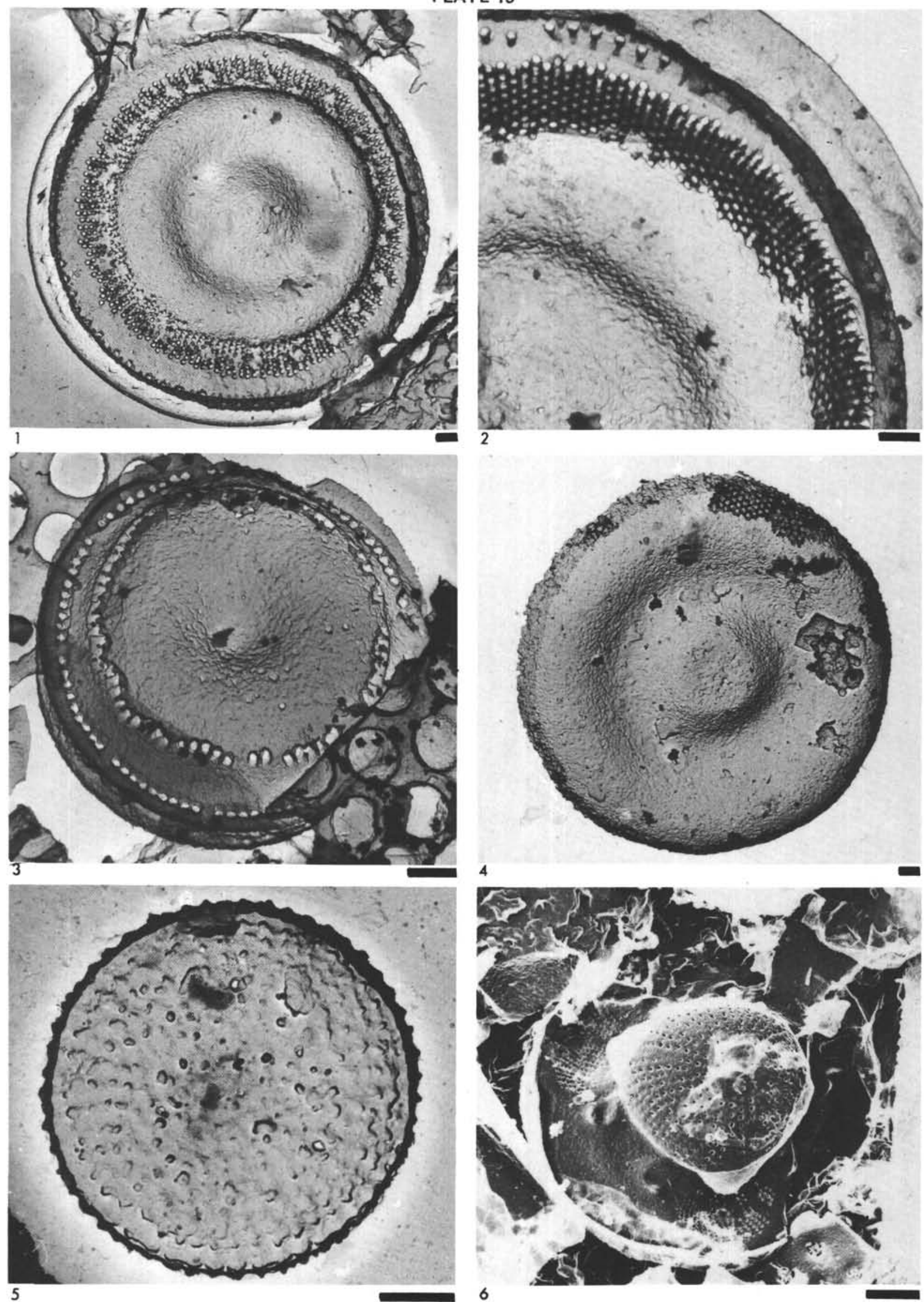


\section{PLATE 20}
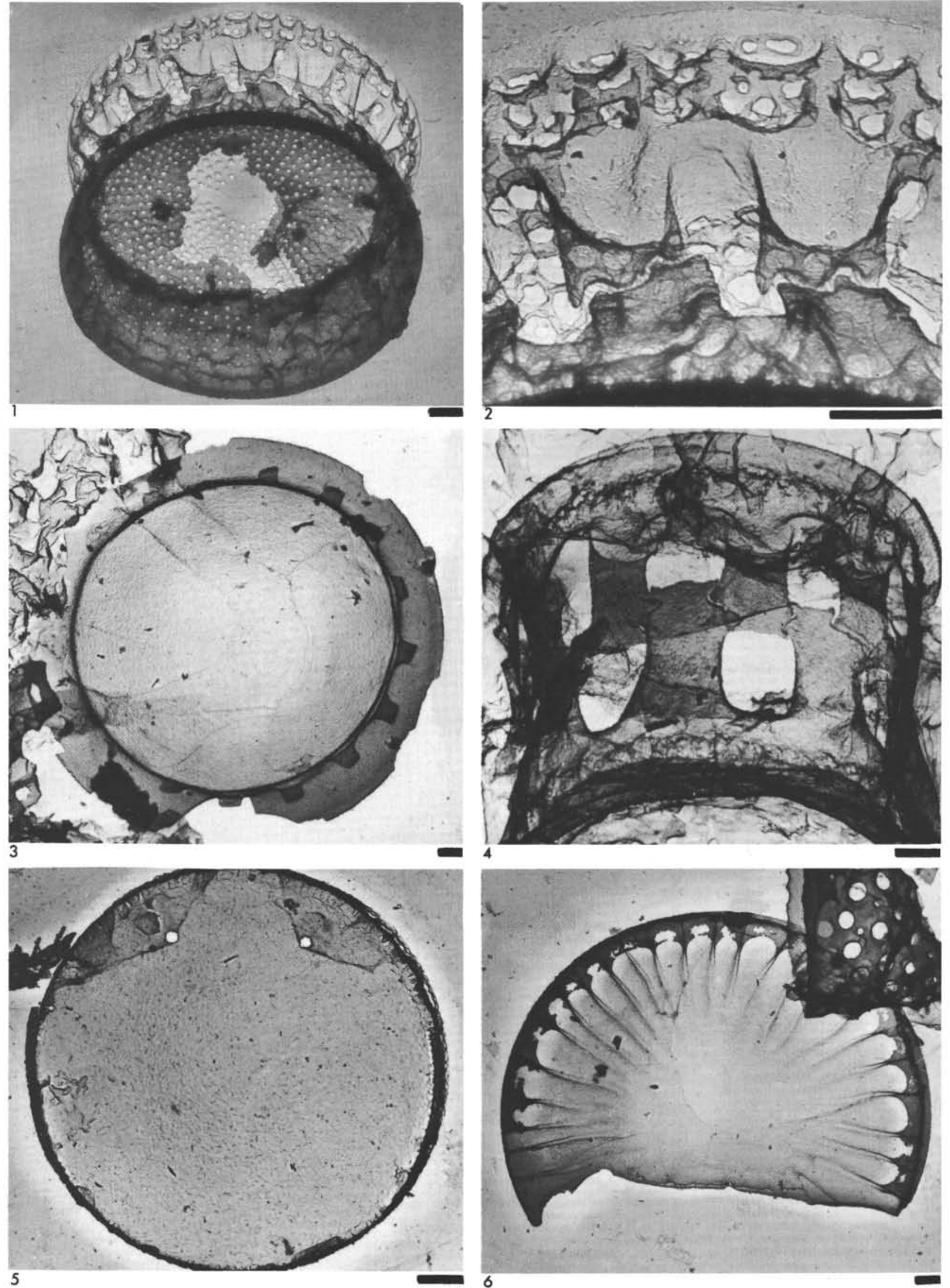
PLATE 21

Cretaceous diatoms from Sample 2-1, 130-132 cm

Stephanopyxis sp.

Figure 1 Valve view, external side; areolae closed by compact membranes; double row of pores near the margin; $\times 7500$.

Figure 2 Valve view, external side of a valve with five apical spines; areolae closed except for the marginal ring of pores; $\times 7500$.

Figure 3 Valve view; external side with apical spines; $\times 4400$.

Figure $4 \quad$ Valve view of interior side showing the radial rows of marginal pores, and the membranes occluding the areolae; broad hyaline marginal rim; $\times 5250$.

Figure 5 Interior view of a valve showing structure of the wall and granulation of the inner membrane occluding the areolae; $\times 15,000$.

Figure 6 Same view as Figure 5, but slightly tilted, showing double row of marginal pores; $\times 15,000$.

(See p. 978) 
PLATE 21
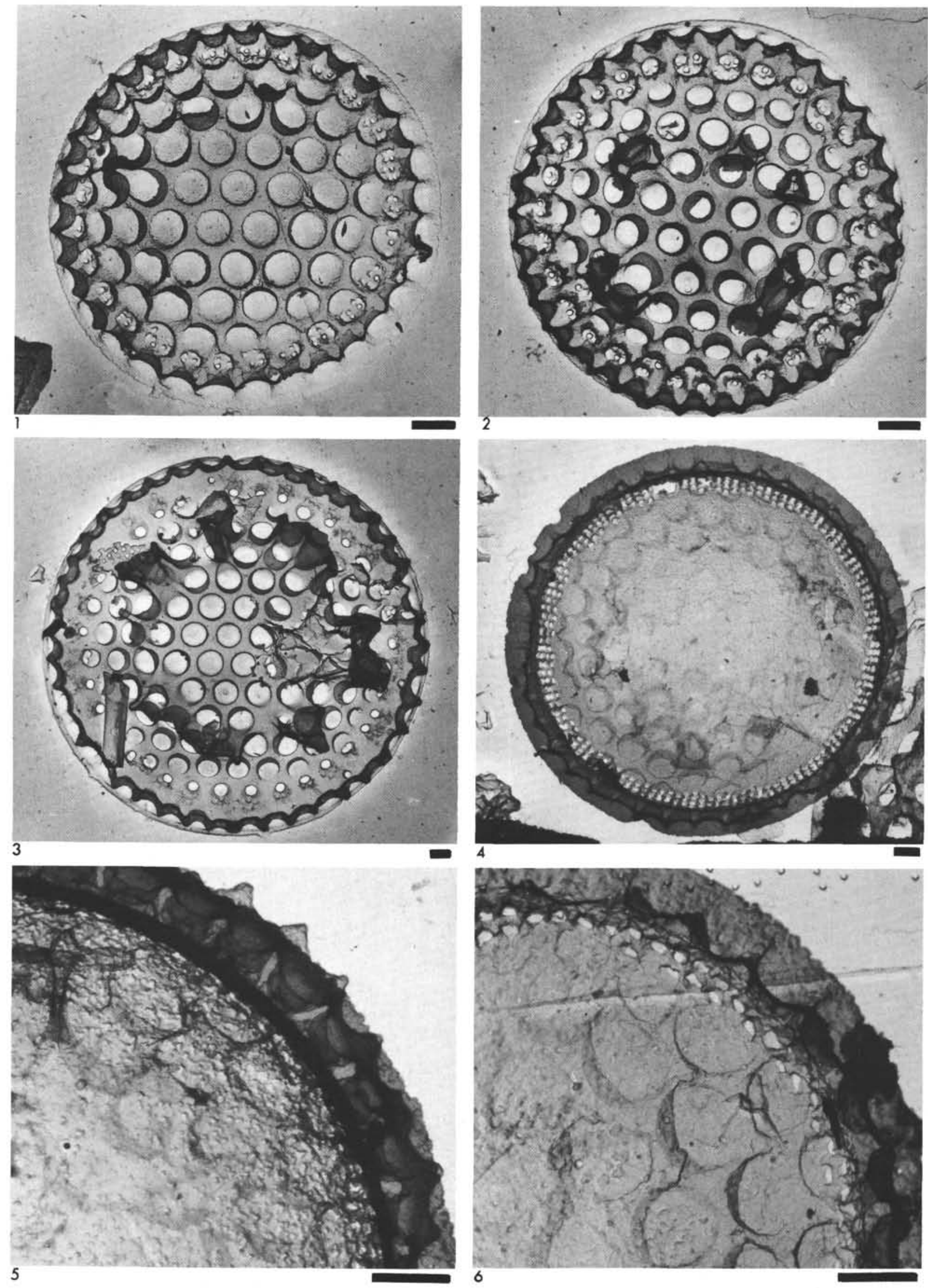


\section{PLATE 22}

Cretaceous diatoms from Sample 2-1, 130-132 cm

Figures 1, 2 Stephanopyxis weyprechtii (Grunow) n. comb. Hajós.

1. Valve view of internal side; $\times 3000$.

2. Internal view of valve; showing grids and one elongate pore; $\times 13,500$.

Figure 3

Stephanopyxis sp. Direct transmission of the margin of a large valve showing ultrastructure of areolae, and larger additional pores; reversed print; $\times 10,400$.

Figure $4 \quad$ Stephanopyxis turris (Greville and Arnott) Ralfs. External view of the apical part of a valve with a view into the cavities of the areolae; reversed print; $\times 7500$.

Figure $5 \quad$ Stephanopyxis cf. weyprechtii Grunow. Direct transmission of part of a valve in oblique view showing how transparent the septa between the areolae are; direct print; $\times 14,000$.

Figure $6 \quad$ Stephanopyxis megapora Grunow. External valve view showing interstitial triangular gaps between the rings surrounding the areolae; $\times 9600$.

(See p. 980) 
PLATE 22



\section{PLATE 23}

Cretaceous diatoms from Sample 2-1, 130-132 cm

Figure $1 \quad$ Stephanopyxis turris (Greville and Arnott) Ralfs. Side view of a valve with comparatively large areolae; $\times 3750$.

Figure 2 Oblique side view of a valve with five apical spines; reversed print of carbon replica; $\times 3300$.

Figure 3 Close up of same specimen as in Figure 2, showing ultrastructure of grids and additional pores from inside; reversed print of carbon replica; $\times 9000$.

Figure $4 \quad$ Same specimen as in Figures 2, 3; apical spines and ultrastructure of apical areolae; direct print; $\times 6000$.

Figure $5 \quad$ Valve view, external side; reversed print; $\times 4000$.

Figure 6 Side view of a complete shell showing connection between two valves; $\times 7000$.

(See p. 982)

PLATE 24

Cretaceous diatoms from Sample 2-1, 130-132 cm

Figures 1-3 Coscinodiscus morenoensis Hanna.

1. Valve view; direct transmission; $\times 1600$.

2. Central part of same specimen as in Figure 1, showing ecentrical elongate pore; direct transmission; $\times 10,000$.

3. Valve view of marginal area of same specimen; direct transmission; $\times 10,000$.

Figures 4, 6 Coscinodiscus $\mathrm{sp}$.

4. Valve view of external side with circular pores in quincunx arrangement; Carbon replica; $\times 12$,000 .

6. Valve view of external side with hexagonal areolae; lower part of the picture shows erosion, and thus the insertion lines of the septa. $\times 10,000$.

Figure 5 ?Coscinodiscus sp. Direct transmission of very fine network of hexagonal areolae with circular pores, two per $1 \mu ; \times 24,000$.

(See p. 983) 
PLATE 23
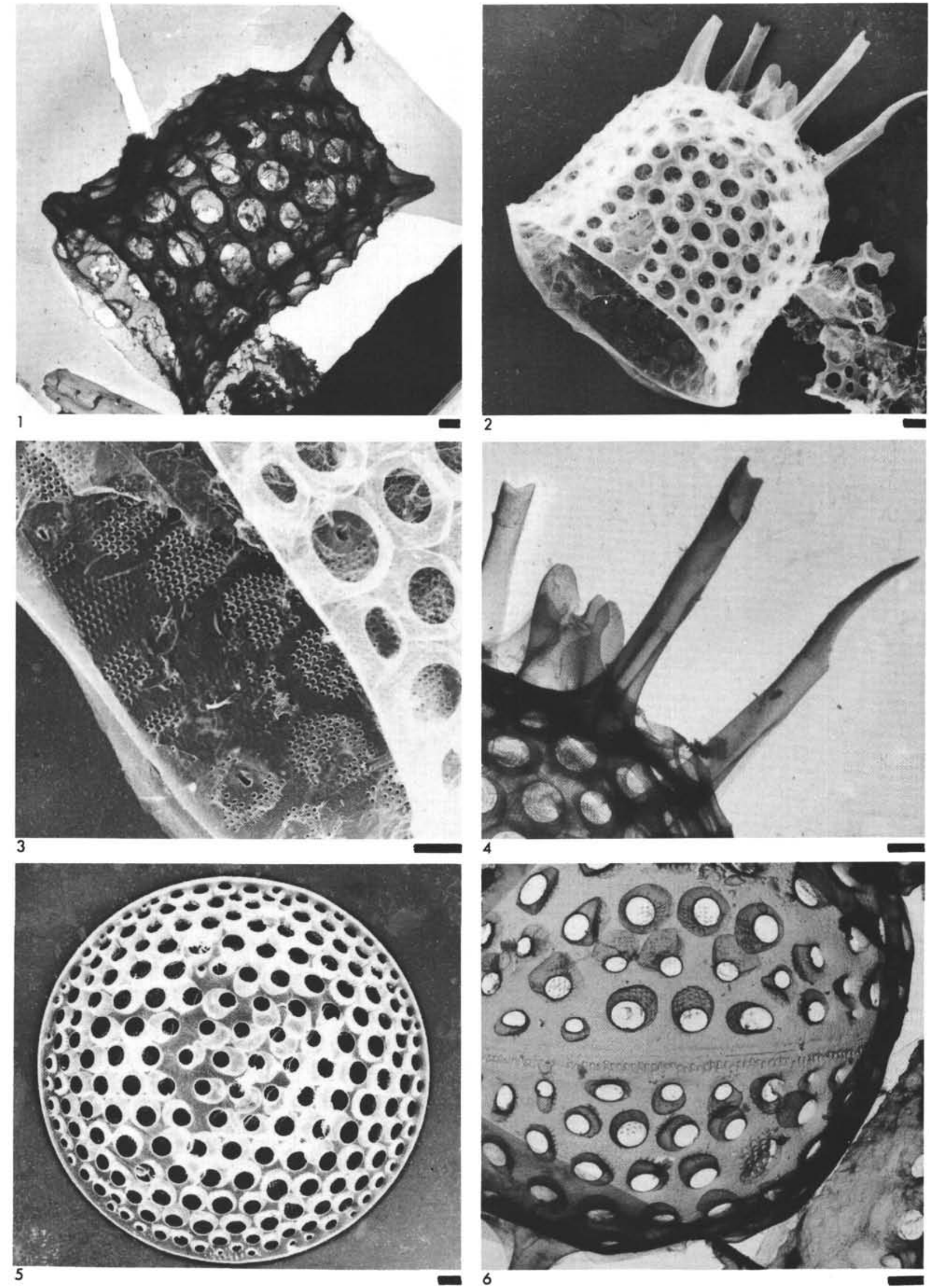
PLATE 24
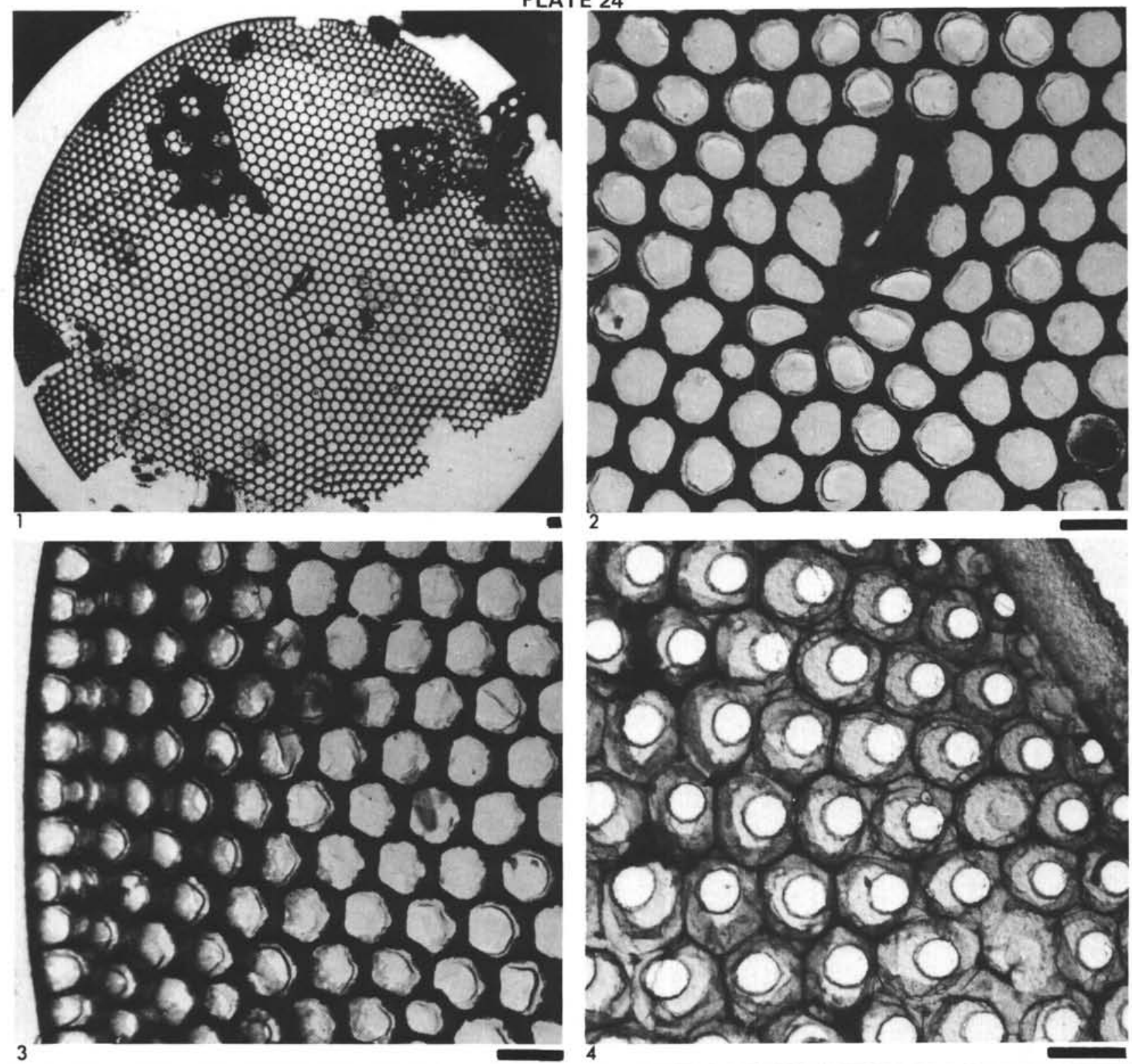

0000000
0000000
000000
000000
000000
01001010

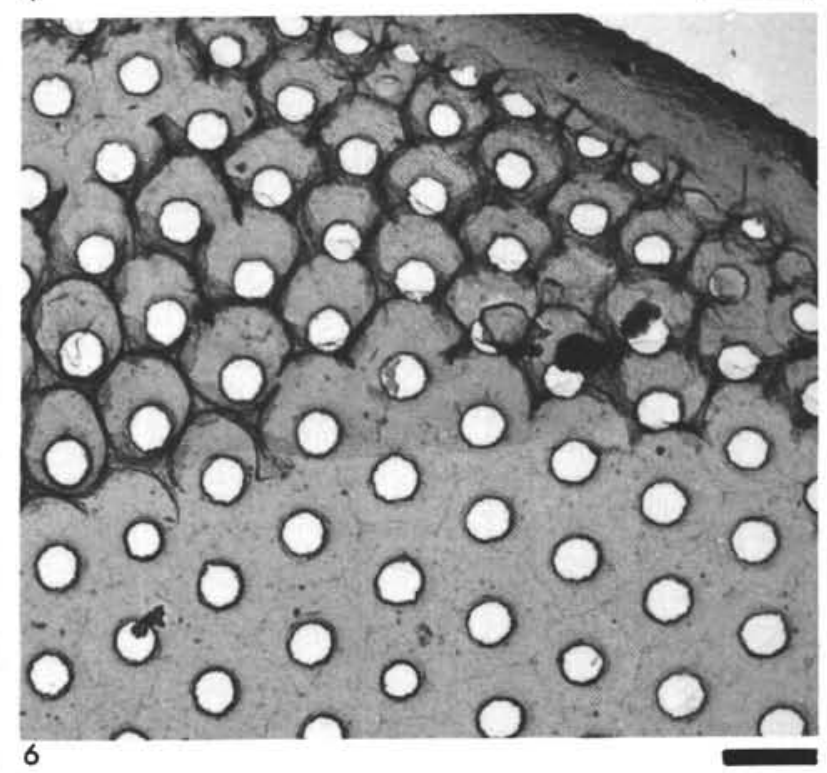




\section{PLATE 25}

Cretaceous diatoms from Sample 2-1, 130-132 cm

Figures 1-5 Coscinodiscus morenoensis Hanna.

1. Valve view of central portion showing fasciculation of areolae; external view; $\times 3000$.

2. "Navel" of same specimen with ecentrical oval pore; normal exposure, direct print; each areola has a wavy inner contour; external view; $\times 12,500$. 3 . Same negative as in Figure 2 after overexposure, showing the interior of the areolae and the circular contour of the inner pore; carbon replica; direct print; $\times 12,500$.

4. Irregular borderline between two fasciculi of rows of areolae; external view; $\times 12,000$.

5. Pattern of areolae with irregular "step" marking the boundary between two fasciculi of rows; external view; $\times 15,000$.

Figure 6 ?Coscinodiscus sp. Characteristic ultrastructure of hexagonal areolae, the craters of which are connected with each other by means of lateral pores; reversed print; $\times 17,500$. 
PLATE 25
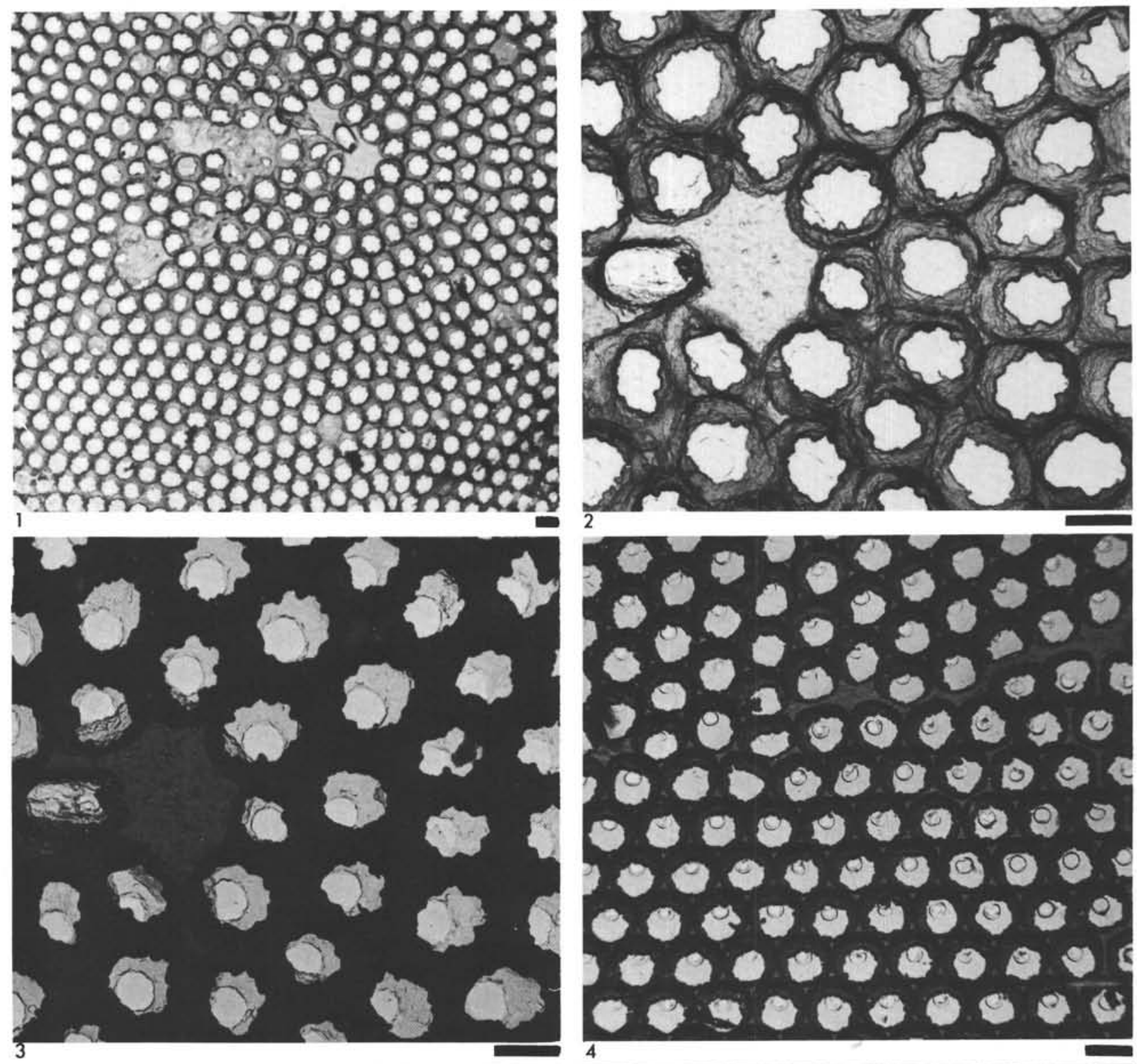

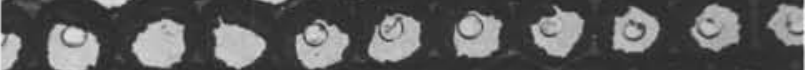

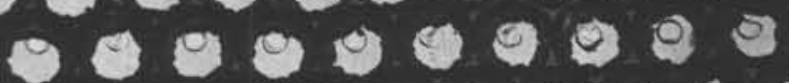
700 a d o o o o


3000 क क क क क



PLATE 26

Cretaceous diatoms from Sample 2-1, 130-132 cm

Figure 1 Pterotheca cretacea n. sp. Hajós and Stradner. Side view of the entire frustula; basal end (left) shows characteristic double spines with pores close to the margin; reversed print of carbon replica; $\times 5400$.

Figure 2 Gladius pacificus n. sp. Hajós and Stradner. Side view of broadened end; hexagonal to rounded areolae with irregular number of inner circular pores; $\times 6000$.

Figure 3 Gladius speciosus Schulz. Ultrastructure of unusually large areolae; inner pores at random or in quincunx arrangement; $\times 7000$.

Figures 4, $5 \quad$ Xanthiopyxis granti Hanna.

4. Oblique side view of frustula; reversed print; external view; $\times 4125$.

5. Central area of valve in top view showing craters of central pore and surrounding pores; $\times 8000$. 


\section{PLATE 26}
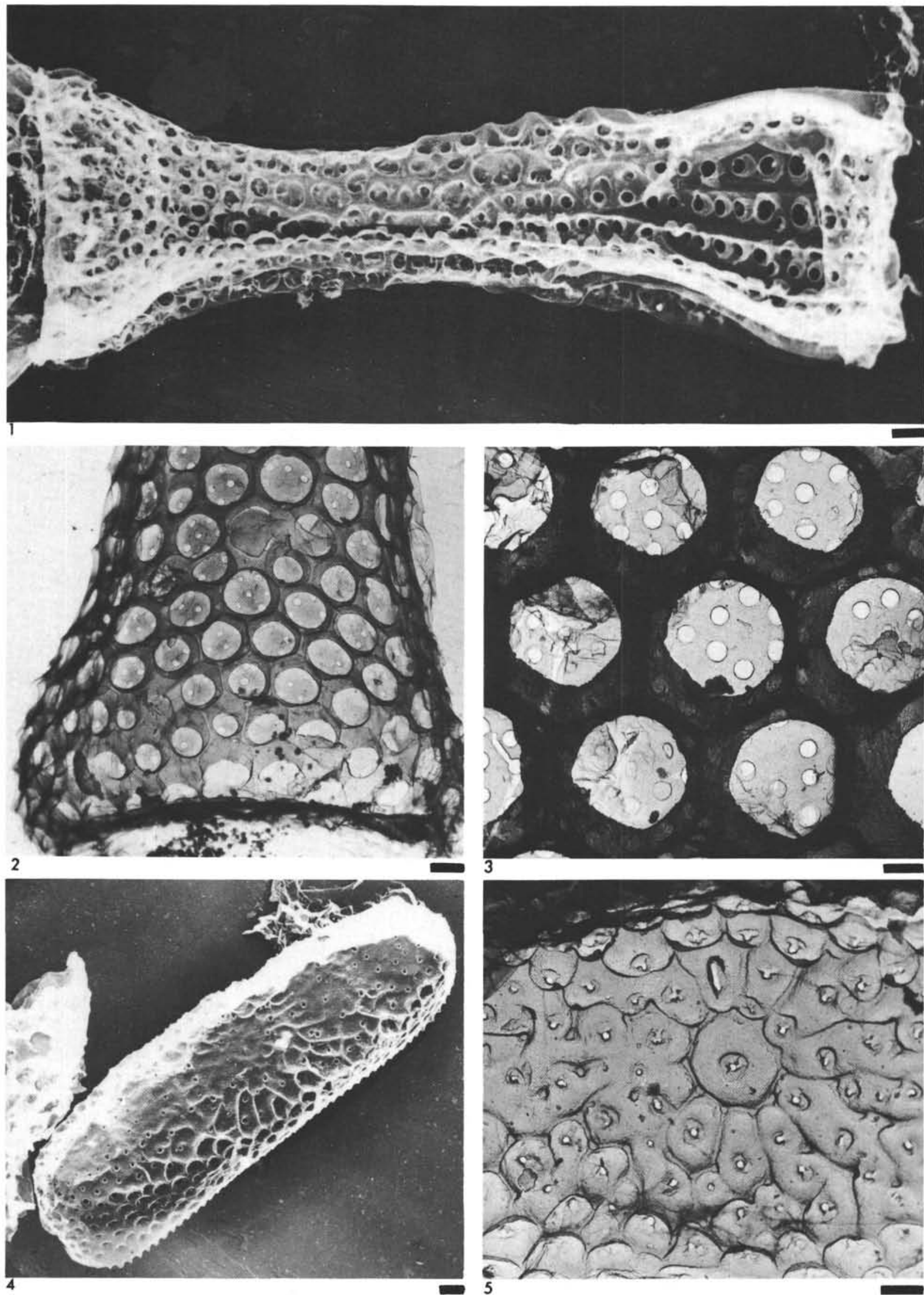


\section{PLATE 27}

Cretaceous diatoms from Sample 2-1, 130-132 cm

Figures 1, 2 Epithelion russicum Pantocsek. Valve view.

1. $\times 3300$.

2. $\times 3500$.

Figures 3, 5, 6 Chasea bicornis Hanna.

3. Valve view; direct transmission; direct print; $\times 3000$.

5. Valve view of specimen similar to that of Figure

3 ; external side; $\times 4000$.

6. Broad valve with central protuberance in valve view; external view; $\times 4500$.

Figure 4 Chasea ornata $n$. sp. Hajós and Stradner. Oblique valve view; scanning electron micrograph by $\mathrm{G}$. Lechner, Reicheirt, Austria; $\times 2000$.

Figure 7 Pterotheca crucifera Hanna. Side view of complete permanent spore; $\times 3500$.

Figure $8 \quad$ ?Chasea bicornis Hanna. Side view; $\times 7500$.

Figure 9 Pseudopyxilla russica (Pantocsek) Forti. Side view; $\times 5250$. 
PLATE 27
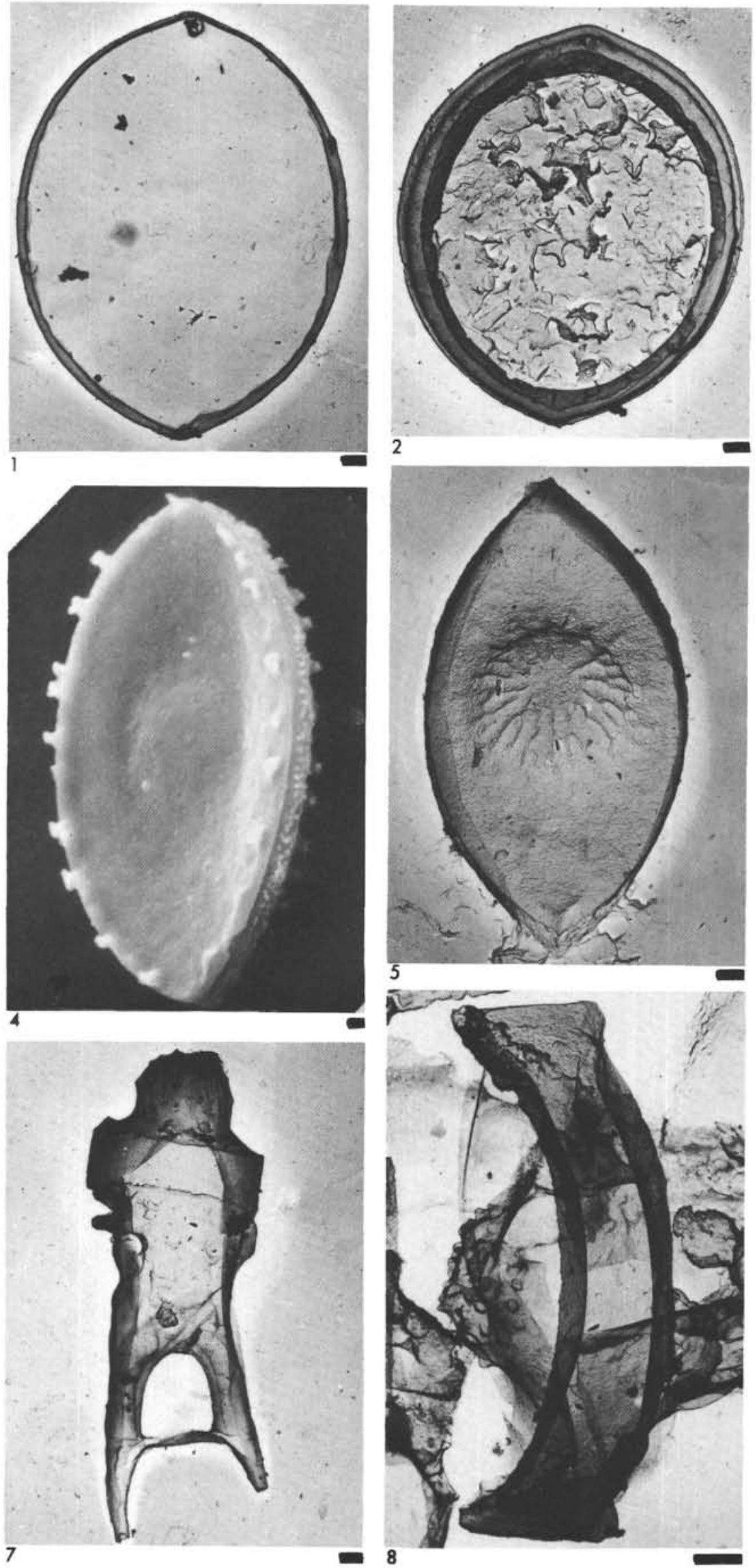
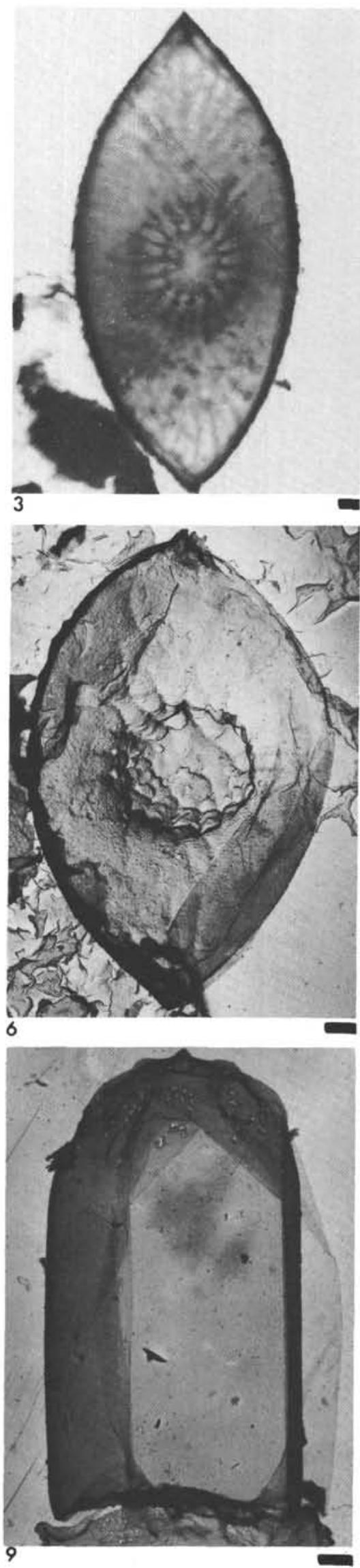
PLATE 28

Cretaceous diatoms from Sample 2-1, 130-132 cm

Figure $1 \quad$ Pterotheca cf. aculeifera Grunow. Side view; $\times 4000$.

Figure 2 Pterotheca aculeifera Grunow. Side view; $\times 2650$.

Figure 3 Pterotheca crucifera Hanna. Side view; $\times 4330$.

Figure 4 Acanthodiscus ornatus n. sp. Hajós and Stradner. Oblique apical view showing central protuberance and marginal ridges; $\times 3000$.

Figure $5 \quad$ Cladogramma simplex n. sp. Hajós and Stradner. Valve view; external side; $\times 4000$.

Figure 6 Acanthodiscus convexus n. sp. Hajós and Stradner. Oblique side view showing undulating ridges; $\times 3500$.

PLATE 29

Diatoms from Sample 2-1, 130-132 cm

Figures 1-4 Actinoptychus packi Hanna.

1. Valve view; $\times 5000$.

2. Valve view; $\times 4400$.

3 . Close up of single sector; reversed print; $\times 11,000$.

4. Close up of single sector with marginal pore and hyaline channels; $\times 9500$.

Figures 5, 6 Hemiaulus sporalis Strelnikova.

5. Valve view; $\times 4500$.

6. Central area of same specimen showing radial rows of round pores; $\times 12,000$.

(See p. 992) 


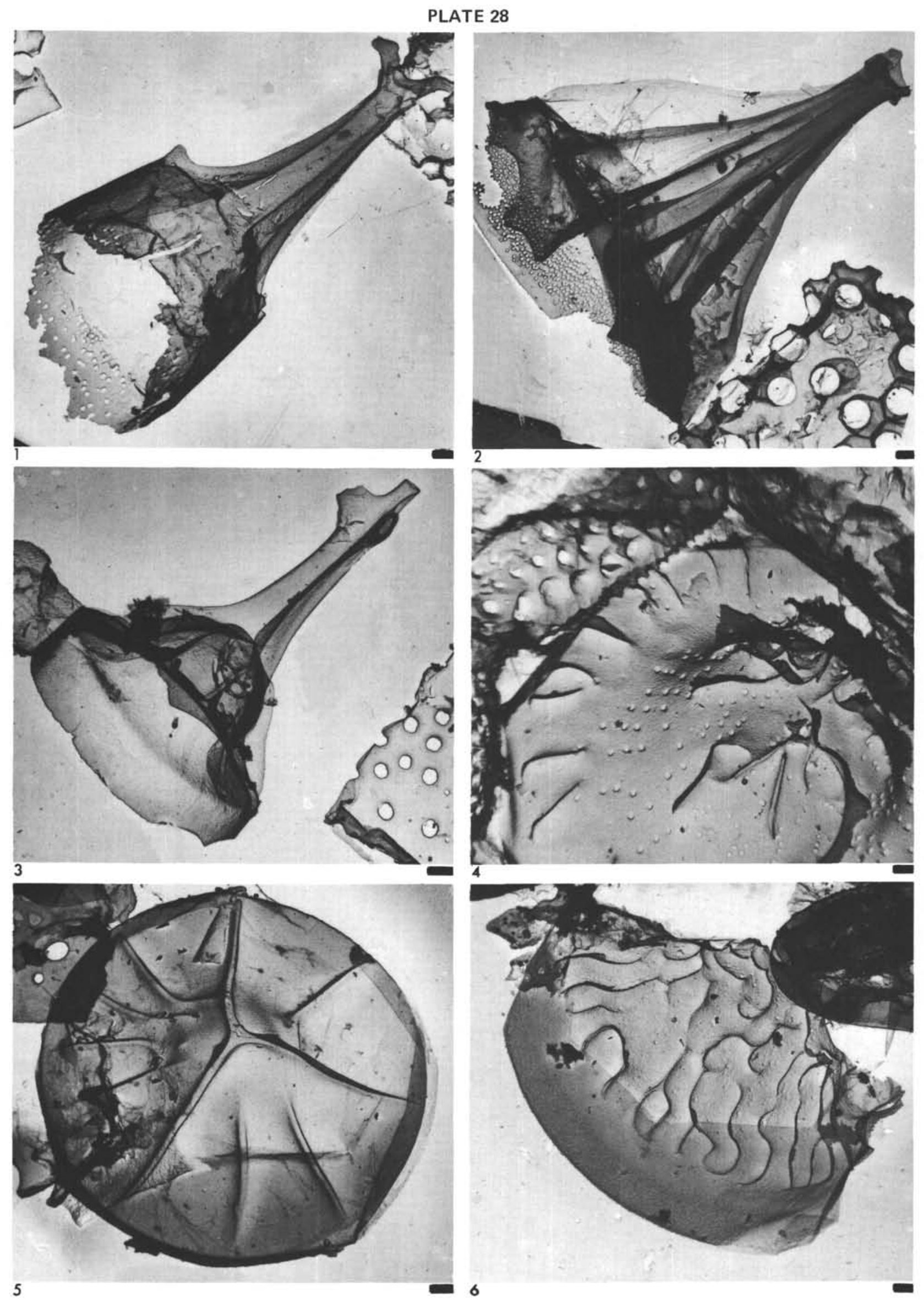



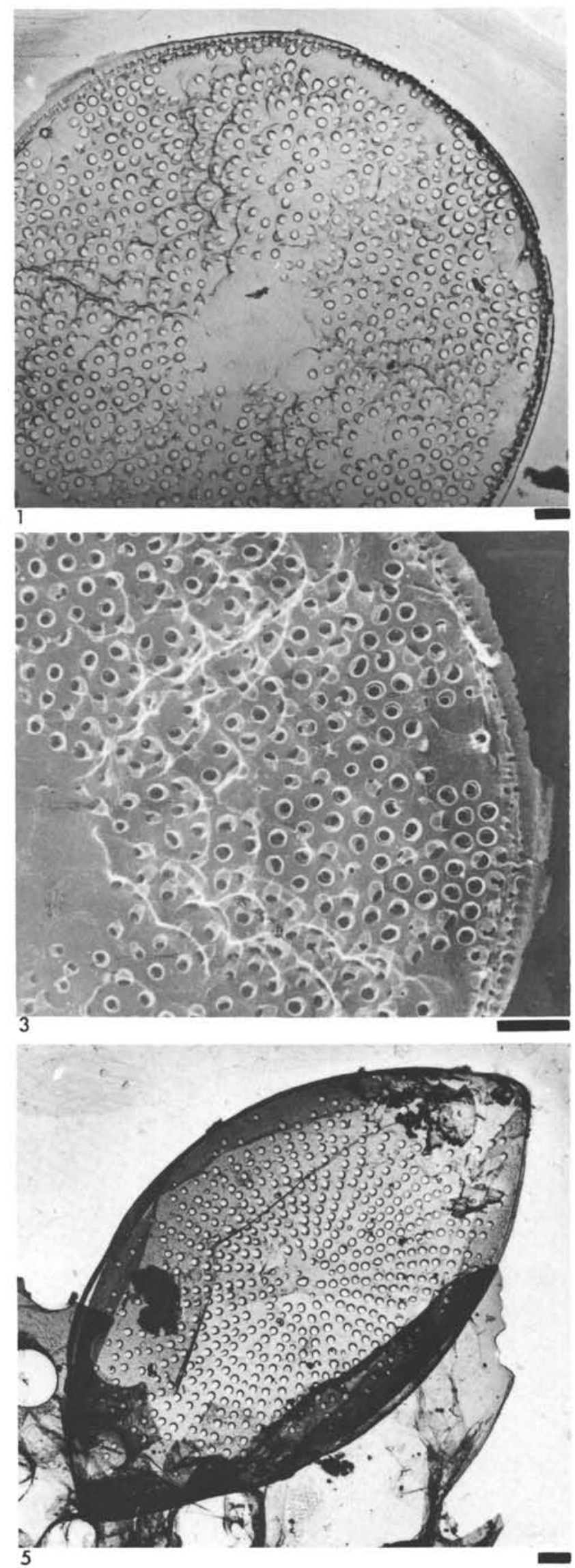





PLATE 30

Cretaceous diatoms from Sample 2-1, 130-132 cm

(Scanning electron micrographs by G. Lechner, Reichert, Austria)

Figures 1-4 Actinoptychus packi Hanna.

1. Plan view, $0^{\circ} ; \times 1500$.

2. Same specimen in oblique view; $60^{\circ} ; \times 1500$.

3. Same specimen in oblique view, $60^{\circ}$, rotated $30^{\circ}$ in respect to position of Figure $2 ; \times 1750$.

4. Same as Figure 3; close up of central portion, $60^{\circ} ; \times 7500$.

Figure 5 Stephanopyxis turris (Greville and Arnott) Ralfs. Oblique side view of complete frustule, $55^{\circ}$; $\times 1500$.

Figure $6 \quad$ Stephanopyxis sp. Oblique apical view of valve with spines; $45^{\circ} ; \times 1250$.

(See p. 994)

PLATE 31

Cretaceous diatoms from Sample 2-1, 130-132 cm

Figures 1-3 Huttonia antiqua n. sp. Hajós and Stradner.

1. Oblique side view of valve; $\times 3750$.

2. Valve with sparsely distributed rows of pores and terminal sieve plate; $\times 5000$.

3 . Close up of terminal sieve plate and surrounding semilunar double-row of pores; $\times 14,500$.

Figures 4-6 Rhizosolenia cretacea $n$. sp. Hajós and Stradner.

4. Side view; $\times 2700$.

5. Close up of middle portion showing densely perforated stripes between hyaline pillars; $\times 9000$.

6. Proximal end with elongate pore; $\times 10,660$.

(See p. 995) 


\section{PLATE 30}
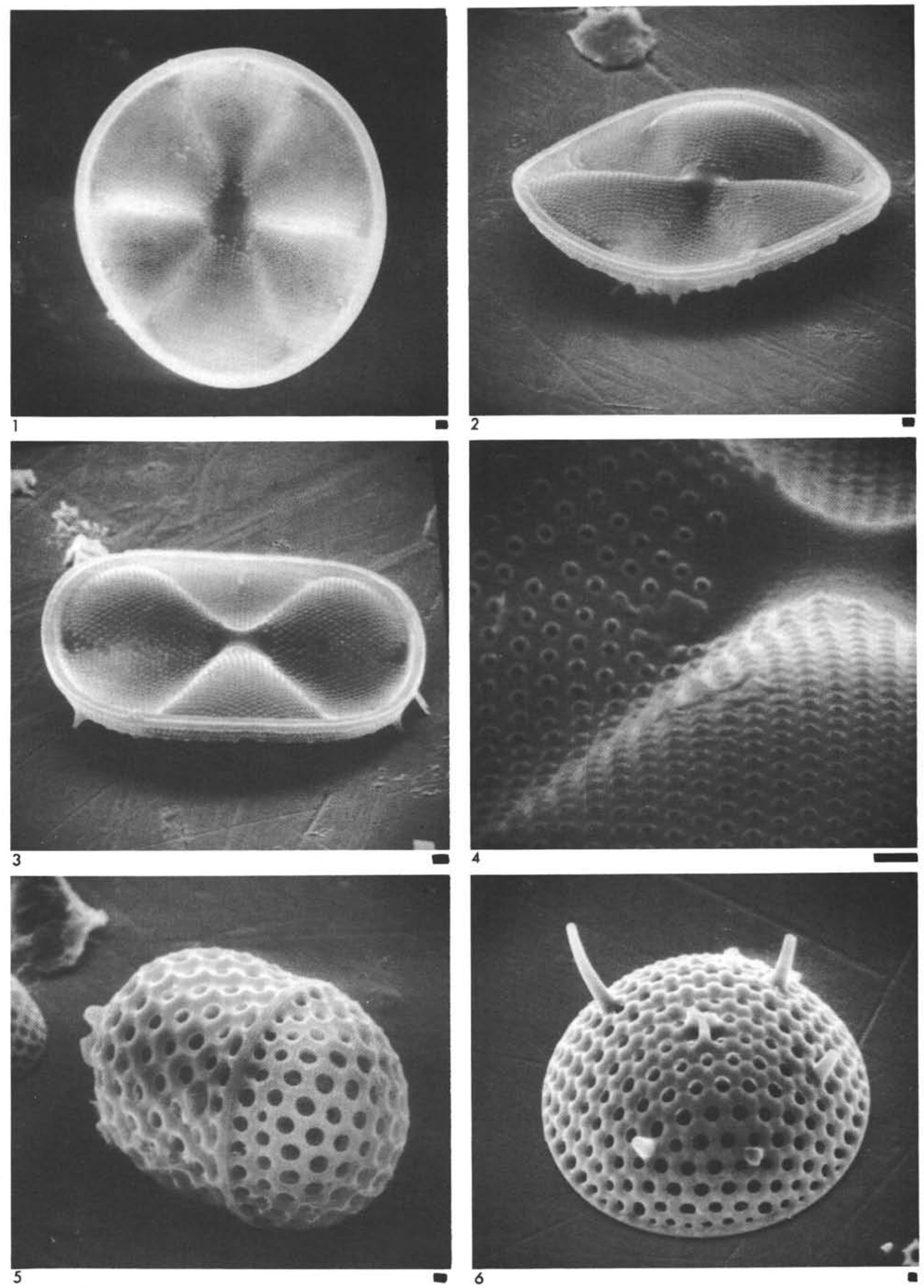



PLATE 31
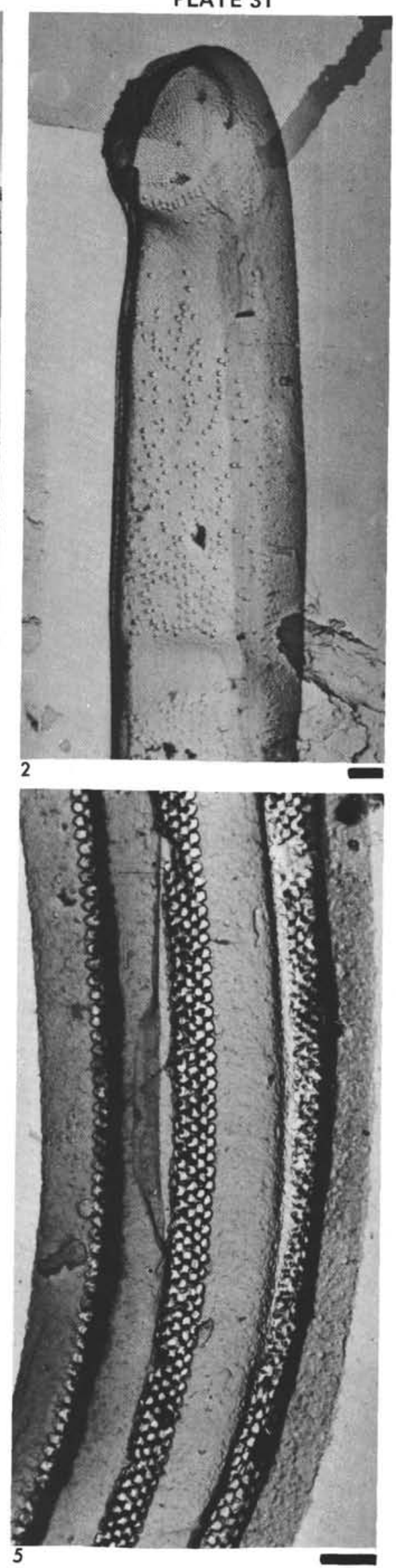

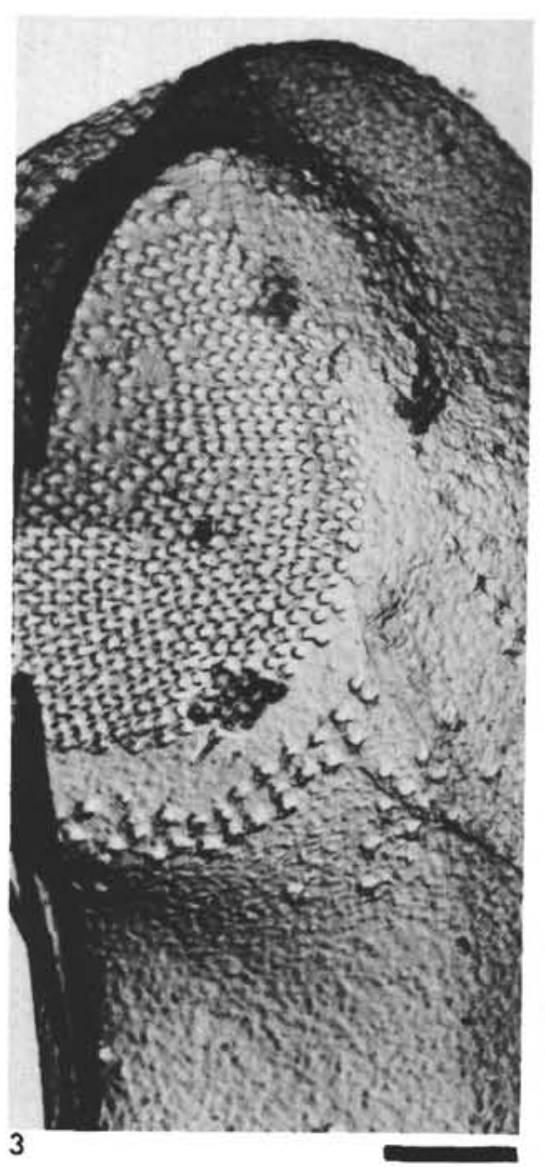

3

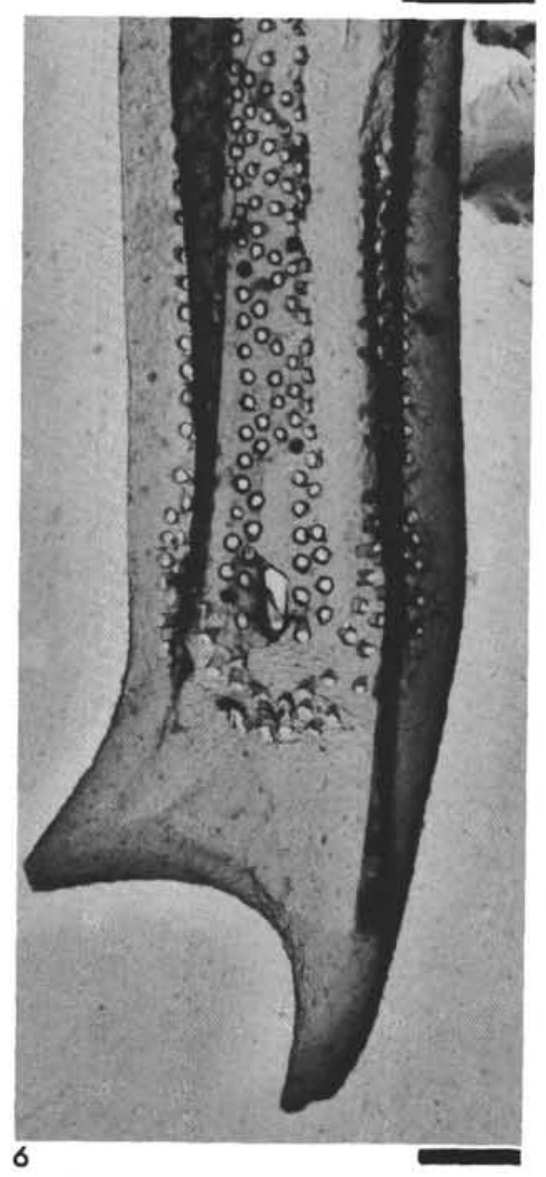


PLATE 32

Cretaceous diatoms from Sample 2-1, 130-132 cm

Triceratium kennetti n. sp. Hajós and Stradner

Figure $1 \quad$ Valve view, internal side; $\times 4125$.

Figure 2 Areolae of side wall, external view, reversed print of carbon replica; $\times 8000$.

Figure 3 Interfingering spines connecting neighboring valves of two adjoining frustulae. Note the different types of grids inside the areolae. $\times 10,000$.

Figure 4 Grids at the bottom of each areola in internal view; reversed print of carbon replica; $\times 15,750$.

Figure $5 \quad$ Small areolae (less than $1 \mu$ ) with delicate grid; direct print; $\times 30,000$.

Figure 6 Side wall with serrate margin towards the girdle; areolae and pores of girdle separated by hyaline zone; $\times 6300$.

\section{PLATE 33}

Cretaceous diatoms of Sample 2-1, 130-132 cm

Figure 1 Triceratium kuepperi n. sp. Hajós and Stradner. Valve view, internal side; $\times 2500$.

Figure 2 Triceratium schulzii Jousé. Valve view, internal side; $\times 3000$.

Figures 3,4 Trinacria sp. $\times 1750$ (by G. Lechner, Reichert/Austria)

3. SEM oblique apical view of valve $\left(55^{\circ}\right)$

4. SEM oblique basal view of valve $\left(55^{\circ}\right)$.

Figure $5 \quad$ Trinacria aries Witt. Valve view, external side; $\times 2500$.

Figure 6 Triceratium idoneum Pantocsek. Valve view, internal side; $\times 3300$.

(See p. 998) 
PLATE 32
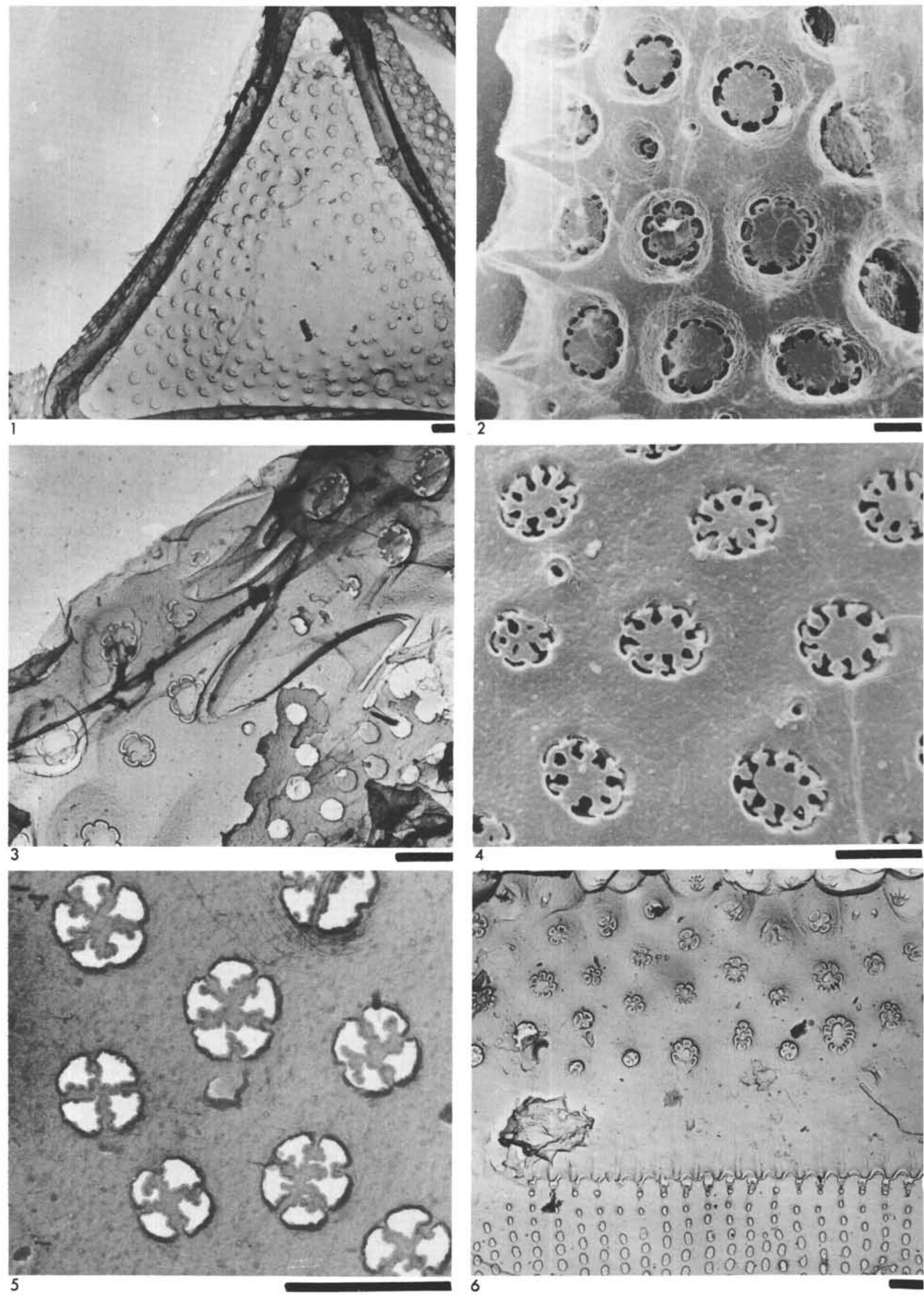
PLATE 33
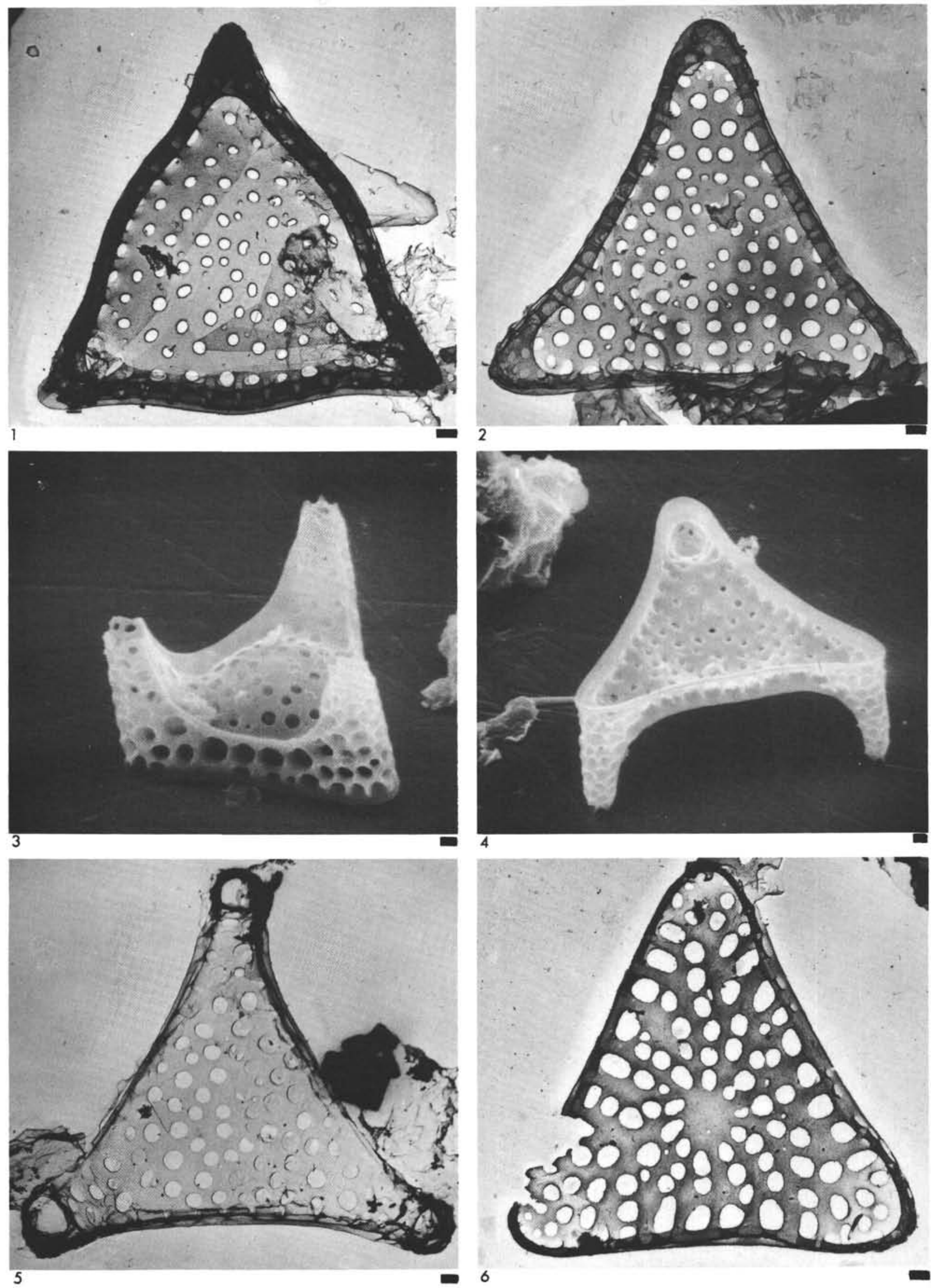


\section{PLATE 34}

Cretaceous diatoms from Sample 2-1, 130-132 cm

Figures 1, 2 Biddulphia cretacea n. sp. Hajós and Stradner.

1. Valve view, external side; $\times 4000$.

2. Central cupula with spine; external side; $\times 8000$.

Figure 3 Hemiaulus polycystinorum Ehrenberg. Lateral view; $\times 3300$.

Figure 4 Hemiaulus cf. polymorphus Grunow. Side view; (in background, apical view of a valve of Stephanopyxis sp.); $\times 3300$.

Figures 5, 6 ?Hemiaulus sp.

5. Side view, valve with rosette-shaped areolae; $\times 3750$.

6. Side view, valve; $\times 3500$.

Figure 7 ?Biddulphia vel Hemiaulus sp. Valve view, internal side; $\times 5500$.

(See p. 1000)

PLATE 35

Cretaceous diatoms from Sample 2-1, 130-132 cm

Figure $1 \quad$ Hemiaulus sp. Side view; $\times 2500$.

Figures 2-5 Hemiaulus polycystinorum Ehrenberg. Side view.

2. Twisted valve, reversed print; $\times 4500$.

3. Reversed print; $\times 4500$.

4. Reversed print; $\times 4400$.

5. $\times 2400$.

Figure 6 Hemiaulus polymorphus Grunow. Side view; $\times 2750$.

Figure 7 Xanthiopyxis granti Hanna. Valve view, internal side with transversal stripes corresponding to the hyaline belts of the outer surface. $\times 4000$.

(See p. 1001) 
PLATE 34


2

PLATE 35



\section{PLATE 36}

Cretaceous diatoms from Sample 2-1, 130-132 cm

Figures 1-4 Sceptroneis praecaducea $\mathrm{n}$. sp. Hajós and Stradner. 1. Valve view, broadened end with sieve plate; external side; $\times 6000$.

2. Valve view, middle portion; internal side; $\times 10,000$.

3. Oblique valve view, broadened end with sieve plate; internal side; $\times 9000$.

4. Valve view, narrow end with elongate terminal pore; external side; $\times 9000$.

Figure 5 Incisoria lanceolata n. sp. Hajós and Stradner. Valve view, notched end with terminal, elongate pore; internal side; $\times 9000$.

Figure 6 Incisoria punctata $\mathrm{n}$. sp. Hajós and Stradner. Valve view of broadened sinuated end. The rows of large pores permit a view of an internal structure; $\times 5330$.

\section{PLATE 37}

Cretaceous diatoms from Sample 2-1, 130-132 cm

Figures 1-4 Pterotheca (Micrampulla) parvula (Hanna) n. comb. Hajós and Stradner.

1. Side view of cyst, reversed print of carbon replica; $\times 5000$.

2. Broken-off tube with external reticulate ornamentation, and longitudinal rows of pores; oblique side view; $\times 11,000$.

3. Oblique side view of the cyst; same specimen as Figure $2 ; \times 8250$.

4. Close up of the cyst showing cratered pores and ruglose wall; $\times 16,000$.

Figure 5 ?Acanthosphaeridium sp. View of a cyst with obliquely crossing ridges surrounding craters with two double-pores; $\times 6750$.

Figure 6 Acanthosphaeridium reticulatum n. sp. Hajós and Stradner. Side view of paratype; $\times 6000$.

(See p. 1004) 
PLATE 36
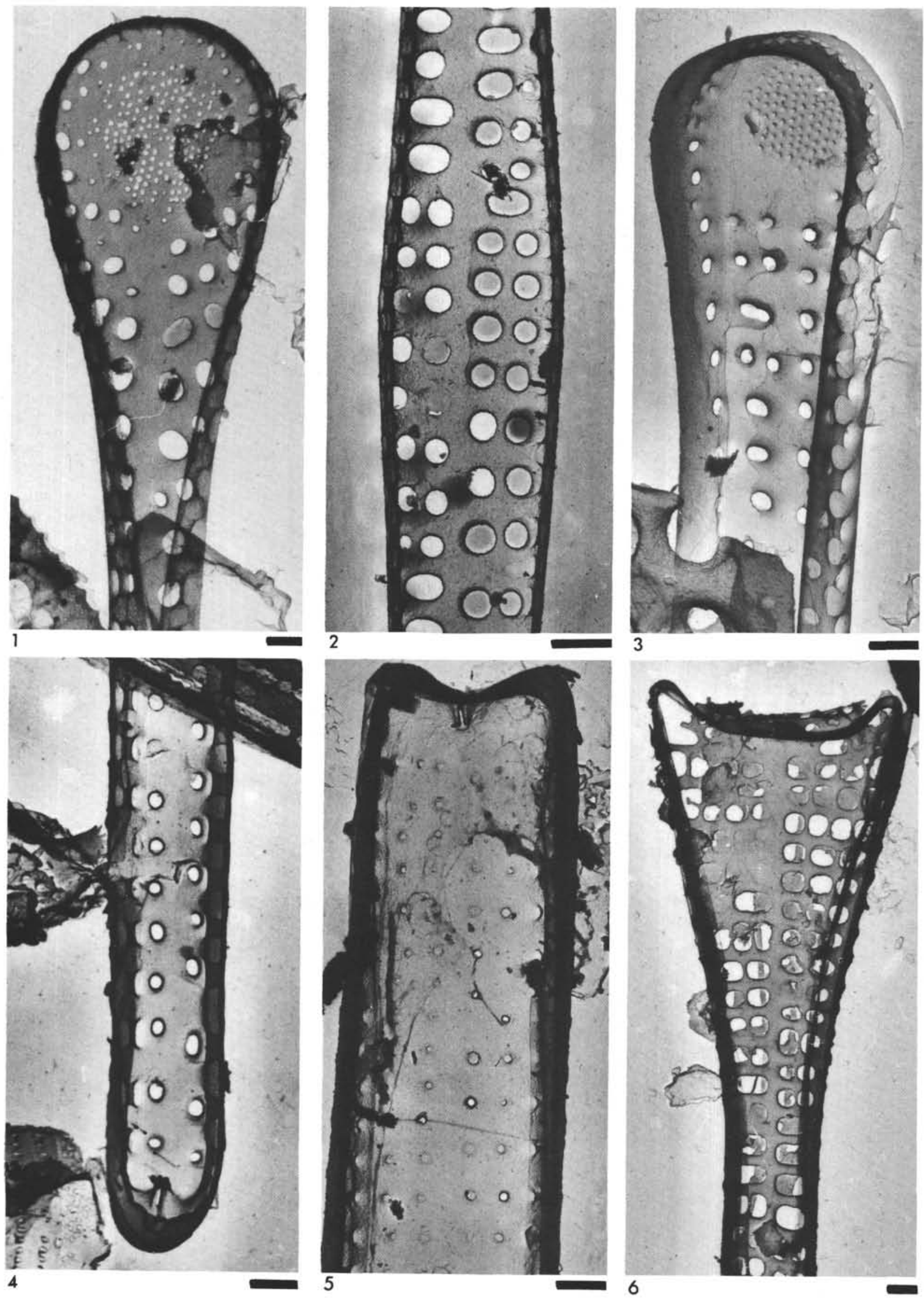
PLATE 37
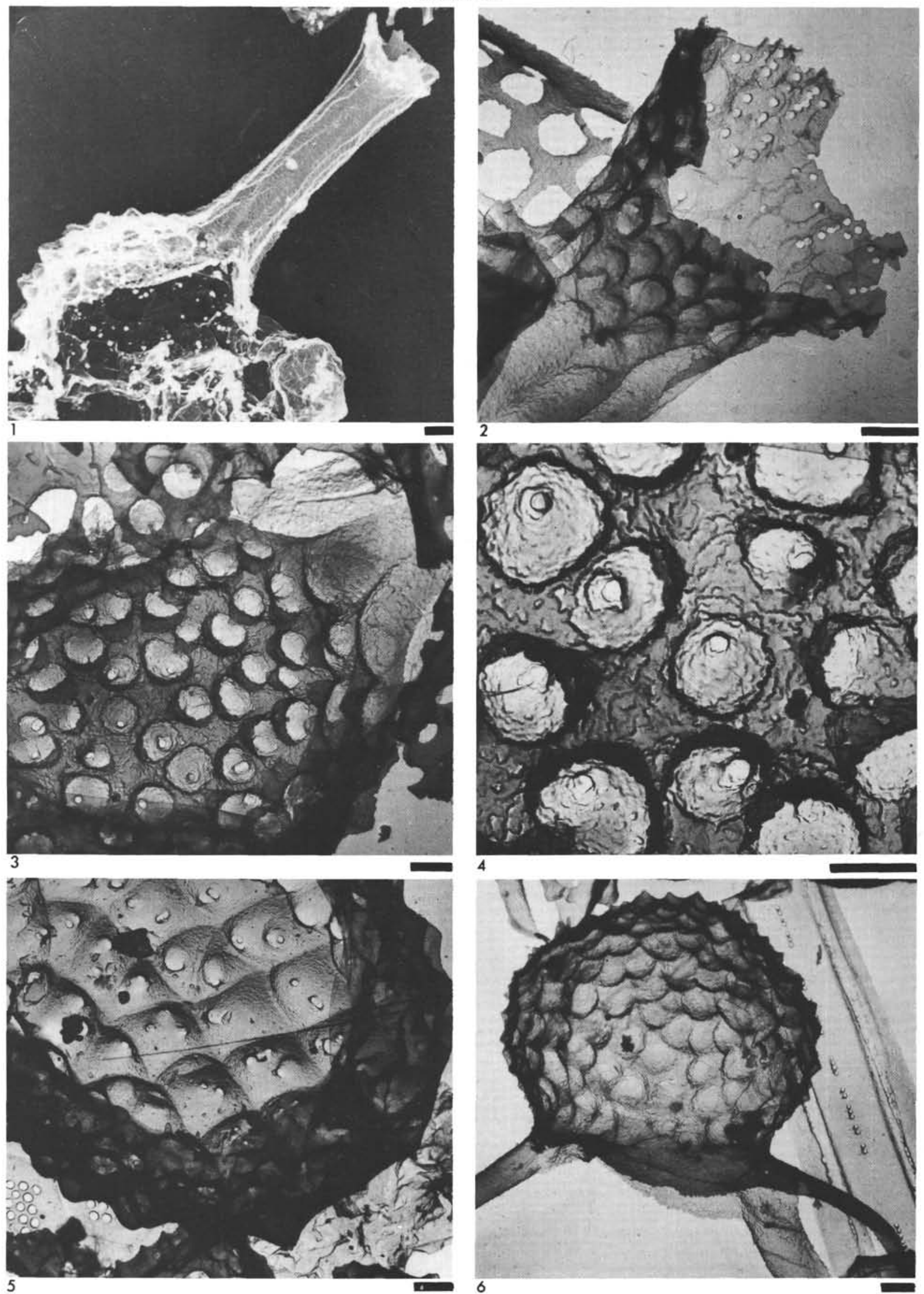


\section{PLATE 38}

Cretaceous diatoms from Sample 2-1, 130-132 cm

Figure 1 ?Coscinodiscus lineatus Ehrenberg forma fossilis Jousé. Direct transmission of marginal zone, direct print; Areolae with 6-8 pores in random distribution; $\times 14,000$.

Figure 2 Genus and species indeterminate. Oblique external view of hexagonal areolae with strictly geometrical inner structure; $\times 7500$.

Figure 3 ?Coscinodiscus sp. Inner wall of areolae with round pores, with septa and external structure eroded; external view; $\times 8000$.

Figure 4 Genus and species indeterminate. Inner side of valve with sieve plates of areolae surrounded by radial grooves; $\times 12,000$.

Figure $5 \quad$ Rattrayella antiqua n. sp. Hajós and Stradner. Marginal pore with sieve plate showing radial rows of pores; $\times 13,000$.

Figure 6 Genus and species indeterminate. A circular valve with hyaline center and radial rows of pores; internal side: Possibly related to Stephanopyxis sp.; $\times 13,000$.

(See p. 1006)

\section{PLATE 39}

Cretaceous Archaeomonadaceae from Sample 2-1, 130-132 cm

Figure 1 Archaeomonas cratera Deflandre. Oblique apical view showing the operculum with surrounding crater; $\times 15,000$.

Figure 2 Archaeomonas chiarugii Rampi. Side view of the cyst with short spines and collar; $\times 12,600$.

Figure 3 Archaeomonas sp. Averted side of a cyst with surface ornamentation of hundreds of warts; $\times 6750$.

Figures 4-6 Artisphaeridium fragile n. sp. Stradner.

4. Generotype, holotype with spines broken off; reversed print of carbon replica; $\times 9000$.

5 . Surface ornamentation of cyst in oblique side view; $\times 45,000$.

6. Surface ornamentation of cyst in apical view. The mushroom-shaped protrusions stand either singly, or are connected with the neighboring ones; $\times 45,000$.

(See p. 1007) 


\section{PLATE 38}

PLATE 39
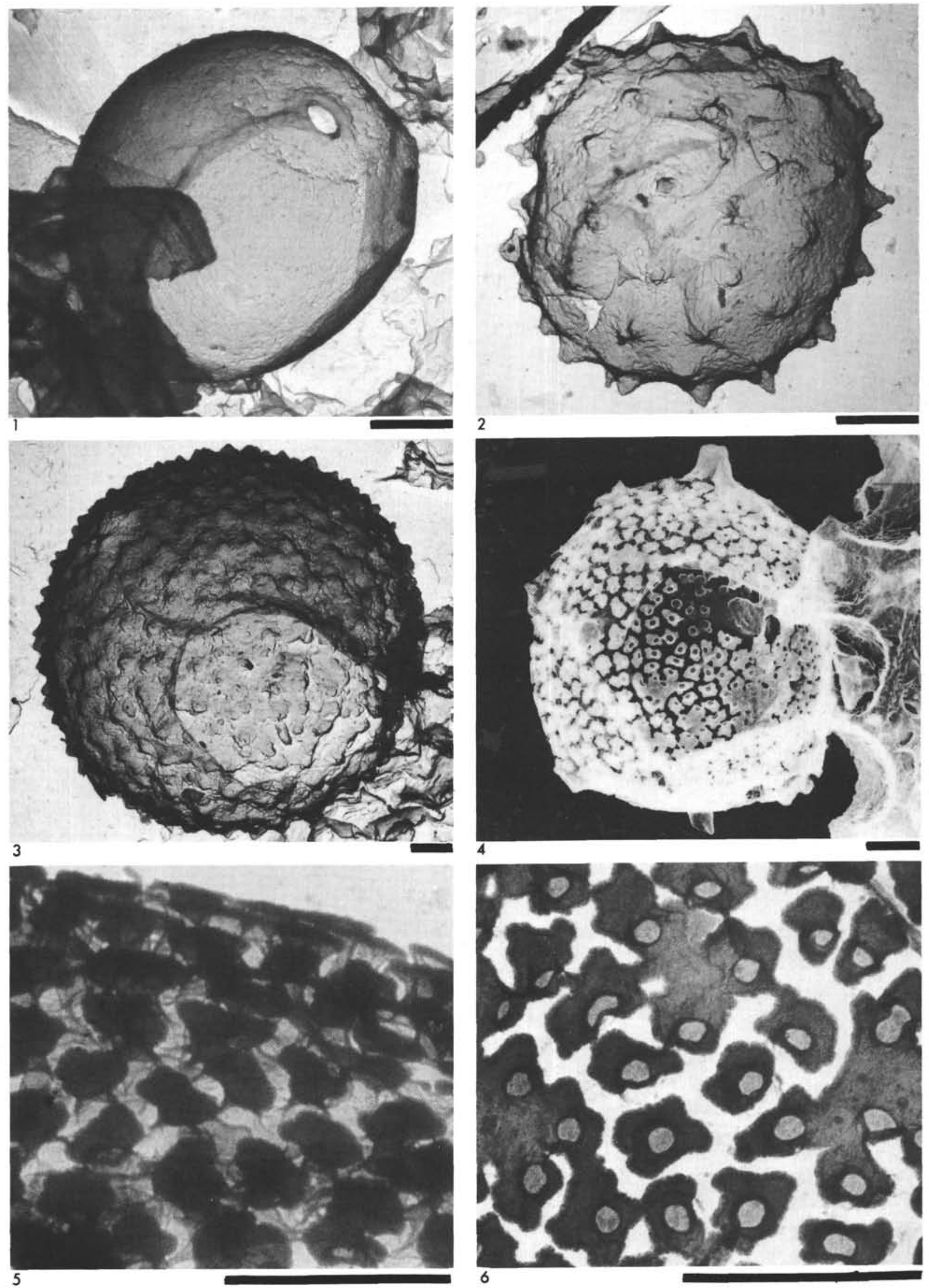


\section{PLATE 40}

Cretaceous Silicoflagellata from Sample 2-1, 130-132 cm

Figure 1 Lyramula furcula Hanna var. minor Deflandre. Plan view; $\times 4000$.

Figure 2 Lyramula furcula Hanna. SEM oblique view (by G. Lechner, Reichert/Austria); $\times 2000$.

Figures 3-5 Lyramula sp.

3. Middle part of arc with spine; $\times 8250$.

4. Fractured arc with oblique view into tube; $\times 8000$.

5. Middle part of arc and spine; reticulate surface ornamentation; $\times 7800$.

Figure 6 Corbisema sp. Oblique view of the basal side of the central area with view into bifurcating tube. $\times 10,600$. 
PLATE 40
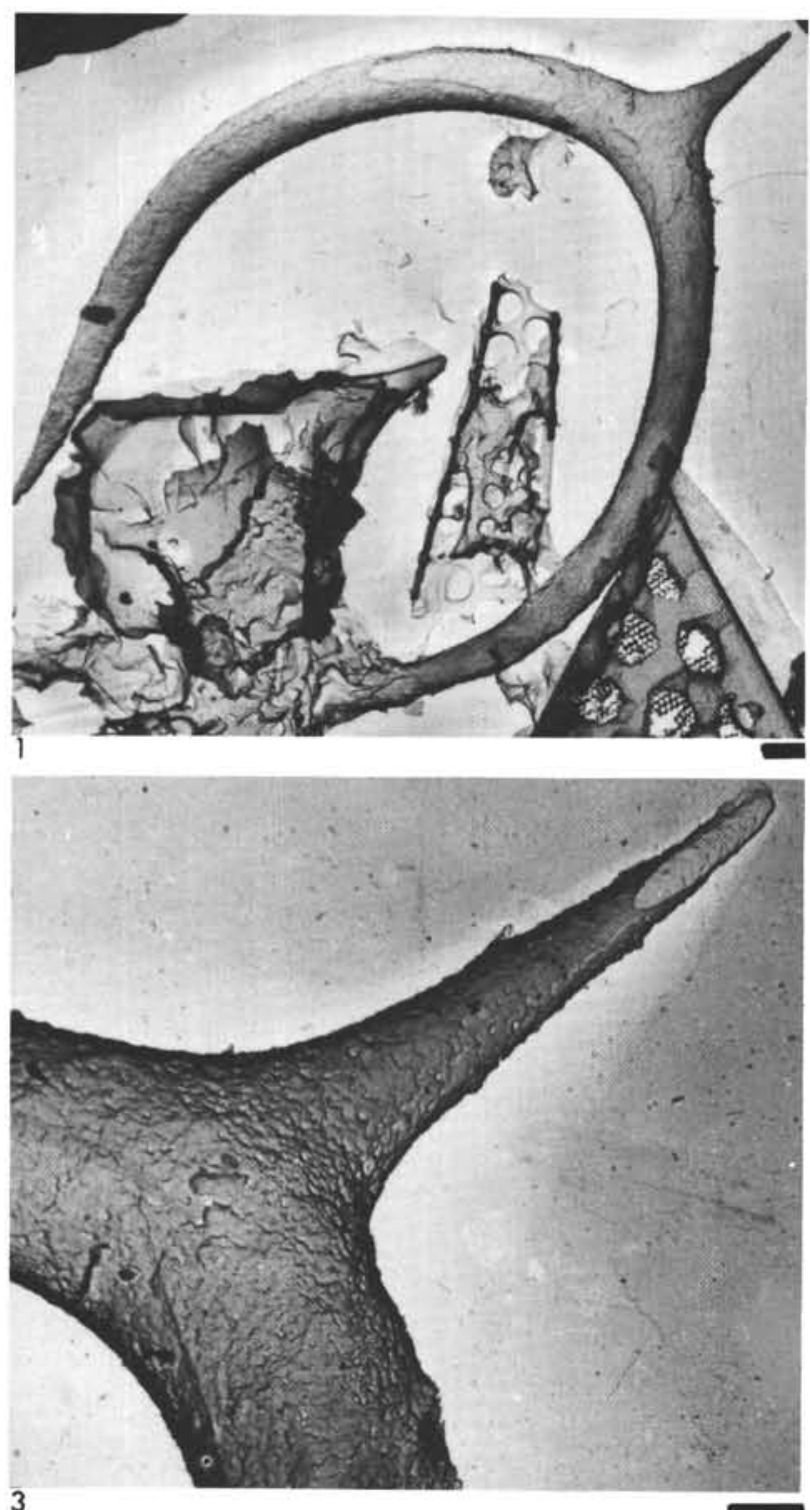

3



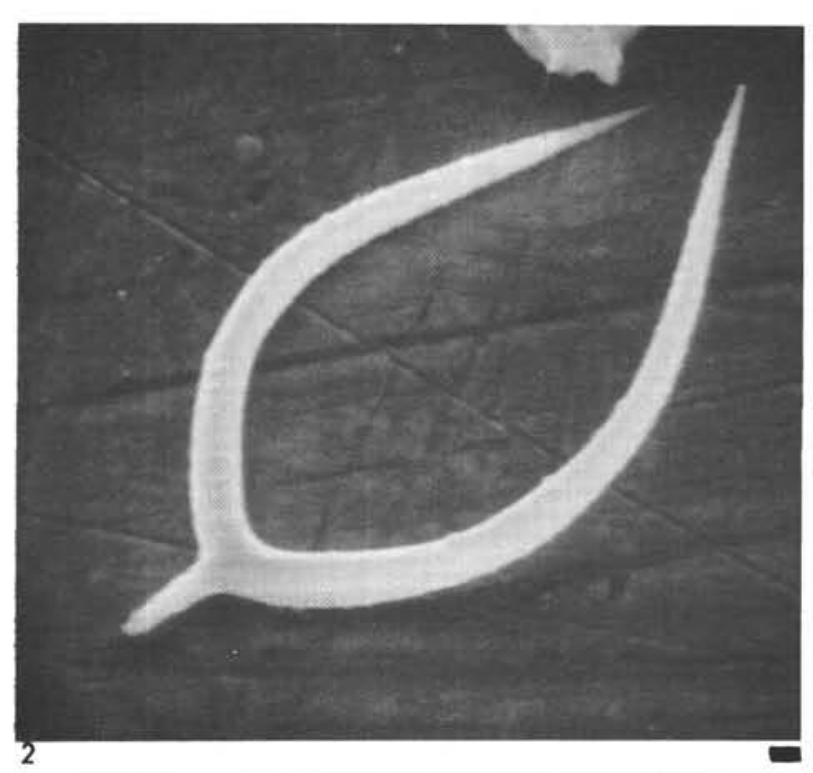
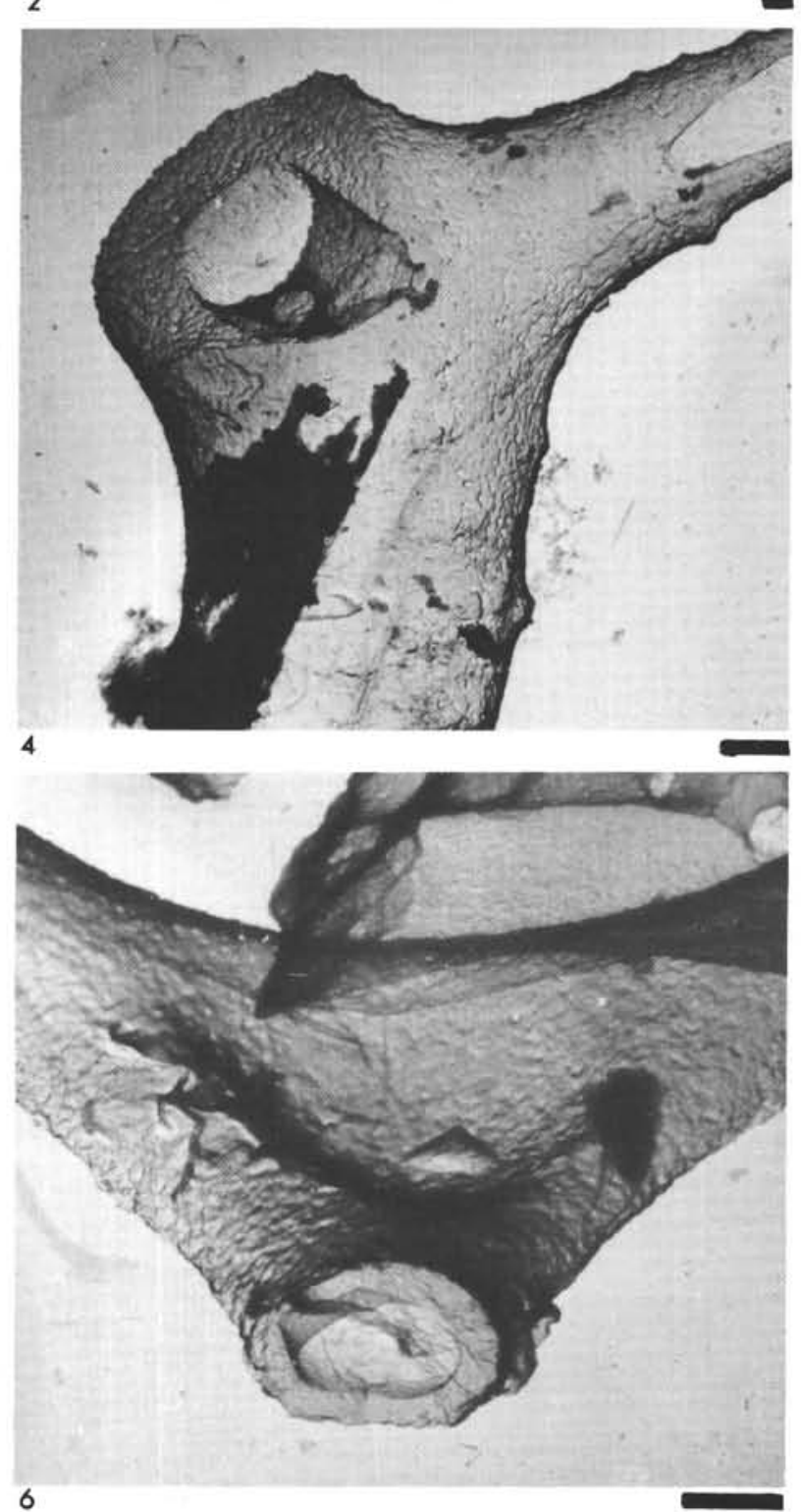